Coelenterata of the Amsden Formation (Mississippian and Pennsylvanian) of Wyoming

GEOLOGICALSURVEY PROFESSIONAL PAPER 848-C 



\section{Coelenterata of the Amsden Formation (Mississippian and Pennsylvanian) of Wyoming}

By WILLIAM J. SANDO

THE AMSDEN FORMATION (MISSISSIPPIAN AND PENNSYLVANIAN) OF WYOMING

GEOLOGICAL SURVEY PROFESSIONAL PAPER 848 -G

Descriptions and illustrations of 11 taxa

of corals and 3 of hydrozoans

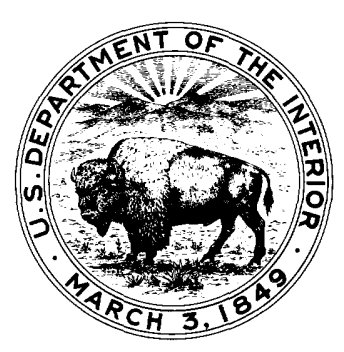




\section{UNITED STATES DEPARTMENT OF THE INTERIOR}

ROGERS C. B. MORTON, Secretary

GEOLOGICAL SURVEY

V. E. McKelvey, Director

Library of Congress Cataloging in Publication Data

Sando, William Jasper.

Coelenterata of the Amsden Formation (Mississippian and Pennsylvanian) of Wyoming.

(The Amsden Formation (Mississippian and Pennsylvanian) of Wyoming) (Geological Survey professional paper ; 848-C)

Bibliography: $p$.

Includes index.

Supt. of Docs. no.: I 19.16:848-C

1. Coelenterata, Fossil. 2. Paleontology-Carboniferous. 3. Paleontology-Wyoming. I. Title. II. Series. III. Series: United States. Geological Survey. Professional paper ; 848-C.

QE777.S35 $\quad 563^{\prime} .5^{\prime} 09787 \quad 74-32116$

For sale by the Superintendent of Documents, U.S. Government Printing Office

Washington, D.C. 20402

Stock Number 024-001-02633-3 


\section{CONTENTS}

Abstract

Introduction --------

Systematic paleontology

Class Hydrozoa

Genus Chaetetes Fischer von Waldheim in

Eichwald, 1829

Class Anthozoa -.-.-.-.-.

Genus Amplexus Sowerby, 1814

Genus Zaphrentites Hudson, 1941 .......-.-

Genus Barytichisma Moore and Jeffords, 1945

Genus Neokoninckophyllum Fomichev, 1939 -

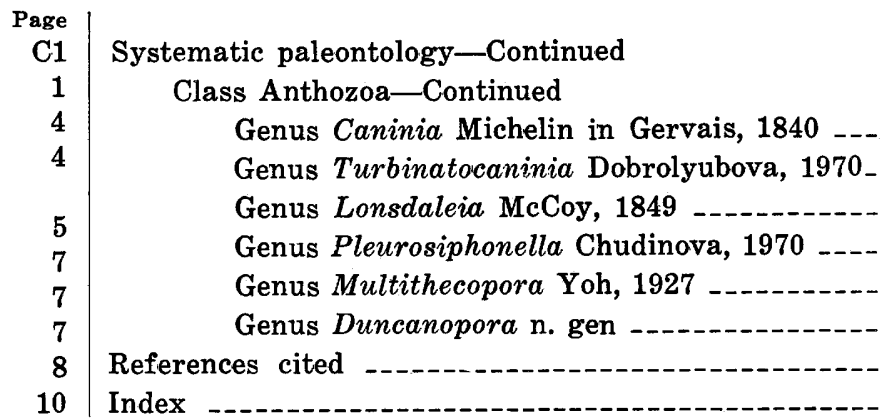

Page

C18

19

20

23

25

25

28

31

\section{ILLUSTRATIONS}

Plate 1. Chaetetes.

[Plates follow index]

2. Chaetetiform bryozoans.

3. Barytichisma amsdenense (Branson and Greger) and "Amplexus" sp. indet.

4, 5. Neokoninckophyllum hamatilis n. sp.

6. Neokoninckophyllum inconstans n. sp.

7. Caninia cf. C. nevadensis (Meek) and Turbinatocaninia? sp.

8. Lonsdaleia (Actinocyathus) stelcki (Nelson).

9. Pleurosiphonella drummondi (Nelson) and Multithecopora? amsdenensis n. sp.

10. Duncanopora duncanae n. sp.

FIGURE 1. Scatter diagram showing relation between alar diameter and number of major septa in Barytichisma amsdenense (Branson and Greger)

2. Scatter diagram showing relation between alar diameter and number of major septa in Neokoninckophyllum hamatilis $\mathrm{n}$. sp

3. Relation between alar diameter and distance above tip in the holotype of Neokoninckophyllum hamatilis n. $s p$

4. Scatter diagram showing relation between alar diameter and number of major septa in Neokoninckophyllum inconstans $\mathrm{n}$. sp

5. Variation in average corallite diameter per colony and average number of major septa per corallite in colonies of Lonsdaleia (Actinocyathus) stelcki (Nelson) from beds of Chesterian age in western North America

6. Corallite diameter and frequency in syringoporoid corals from the Amsden Formation

\section{TABLES}

TABLE 1. Distribution of described coelenterates in the Amsden Formation of Wyoming

2. Checklist of Amsden coelenterate collections

3. Measurements of Chaetetes wyomingensis $\mathrm{n}$. sp. in transverse section

4. Ontogeny in the lectotype (UM 2663) of Barytichisma amsdenense (Branson and Greger) --

5. Ontogeny in a topotype (USNM 165091) of Barytichisma amsdenense (Branson and Greger) -...--

6. Ontogeny in the holotype (USNM 165095) of Neokoninckophyllum hamatilis n. sp

7. Ontogeny in the holotype (USNM 165109) of Neokoninckophyllum inconstans n. sp

8. Ontogeny in a paratype (USNM 165114) of Neokoninckophyllum inconstans n. sp

9. Ontogeny in a paratype (USNM 165115) of Neokoninckophyllum inconstans $\mathrm{n}$. $\mathrm{sp}$

10. Variation in colonies of Lonsdaleia (Actinocyathus) stelcki (Nelson) from the United States and Canada 



\title{
COELENTERATA OF THE AMSDEN FORMATION (MISSISSIPPIAN AND PENNSYLVANIAN) OF WYOMING
}

\author{
By William J. Sando
}

\begin{abstract}
The coelenterate faunas of the Amsden Formation of Wyoming consist of 14 species that represent 11 genera distributed among the chaetetid hydrozoans and the rugose and tabulate corals. Five new species and one new genus are described in this paper. Coelenterates are rare or absent in the Darwin Sandstone, Horseshoe Shale, and Ranchester Limestone Members of the Amsden, but they form a significant part of the invertebrate fauna of the Moffat Trail Limestone Member. Although both Mississippian and Pennsylvanian forms are present in the Amsden, the Moffat Trail fauna, which is of Late Mississippian (Chesterian) age, is the only coelenterate assemblage that is significant for correlation with other strata of similar age.
\end{abstract}

\section{INTRODUCTION}

This report is part of a larger work that deals with the biostratigraphy of the Amsden Formation of Wyoming. The project was undertaken in the belief that the long and complex controversy over the age and correlation of the Amsden could be resolved by means of a comprehensive restudy of its fauna. This report deals only with the coelenterates collected from the Amsden Formation. Details on the stratigraphy of the Amsden and the occurrence of these fossils are given by Sando, Gordon, and Dutro (1974). A summary of the occurrence of the coelenterate fossils of the Amsden is given in table 1 in terms of stratigraphic units and localities described by Sando, Gordon, and Dutro; locality data are recorded in table 2.

Coelenterates form a relatively minor part of the Amsden faunas; the entire assemblage of coelenterate fossils described from the Amsden consists of only 14 species allocated to 11 genera. No coelenterates have been found in the Darwin Sandstone Member, the lowest unit of the Amsden. The Horseshoe Shale Member, a transgressive red siltstone and shale unit that overlies the Darwin, has yielded only an indeterminate Chaetetes and five species of corals representing four genera from rare, thin marine limestone beds at widely scattered localities. Significant elements of this meager fauna are Barytichisma amsdenense (Branson and Greger) from beds of Chesterian age (Anthracospirifer welleri-shawi Zone, Composita poposiensis Subzone) in the Wind River Range and two new species of Neokoninckophyllum from the Rawlins hills, where the Horseshoe Member contains beds of Early Pennsylvanian (Morrowan) age in the upper part (Neokoninckophyllum hamatilis Zone).

The greatest concentration of coelenterates occurs in the richly fossiliferous marine limestone of the Moffat Trail Limestone Member (Caninia Zone) in western Wyoming which has yielded eight species representing eight genera. The Moffat Trail fauna is of Late Mississippian (Chesterian) age. The chaetetid hydrozoans in this fauna are represented by the first true Chaetetes to be described from the Mississippian of North America. The rugose corals are represented by a zaphrentoid species, two cyathopsid species, and a species of Lonsdaleia (Actinocyathus). The tabulate corals are represented by three syringoporoid species assigned to three genera, one of which is new.

The Ranchester Limestone Member, a unit mostly of Pennsylvanian age that overlies the Horseshoe and Moffat Trail Members, has yielded only a single species of Chaetetes. 
TABLE 1.-Distribution of described coelenterates in the Amsden Formation of Wyoming [Localities listed by collection numbers used by Sando, Gordon, and Dutro (1974)]

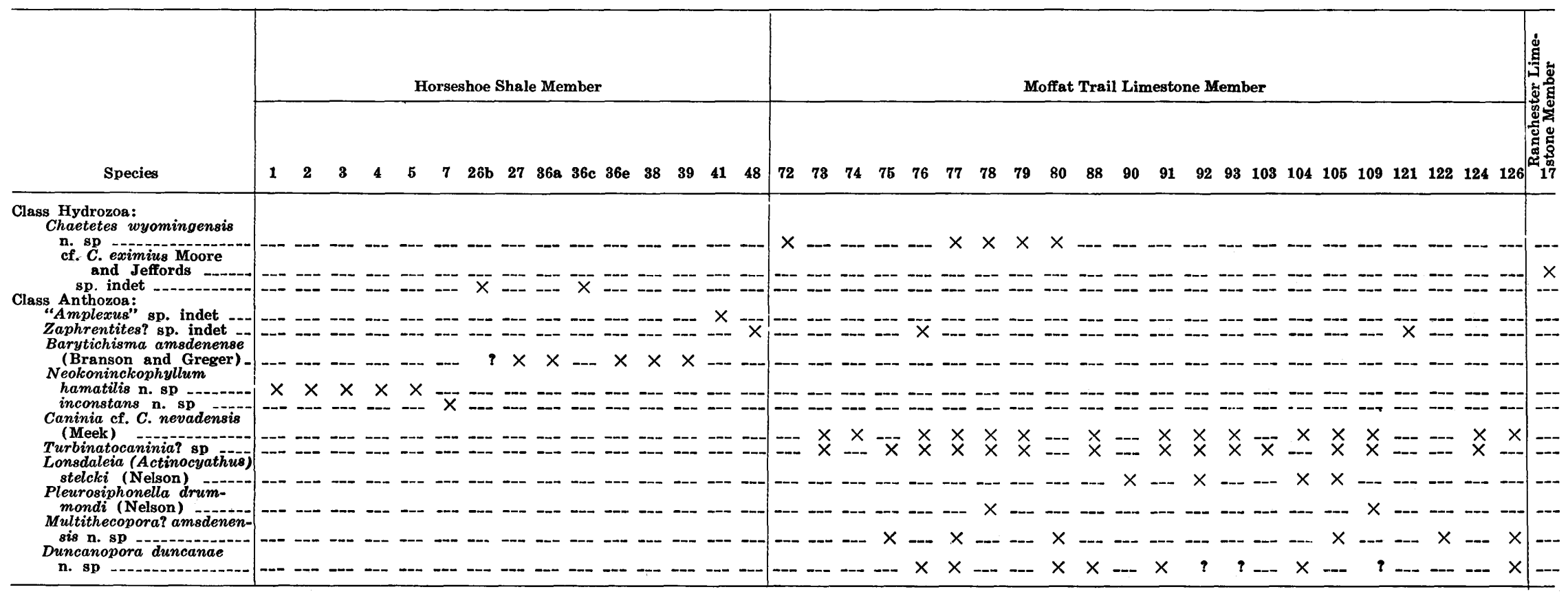


TABLE 2.-Checklist of Amsden coelenterate collection

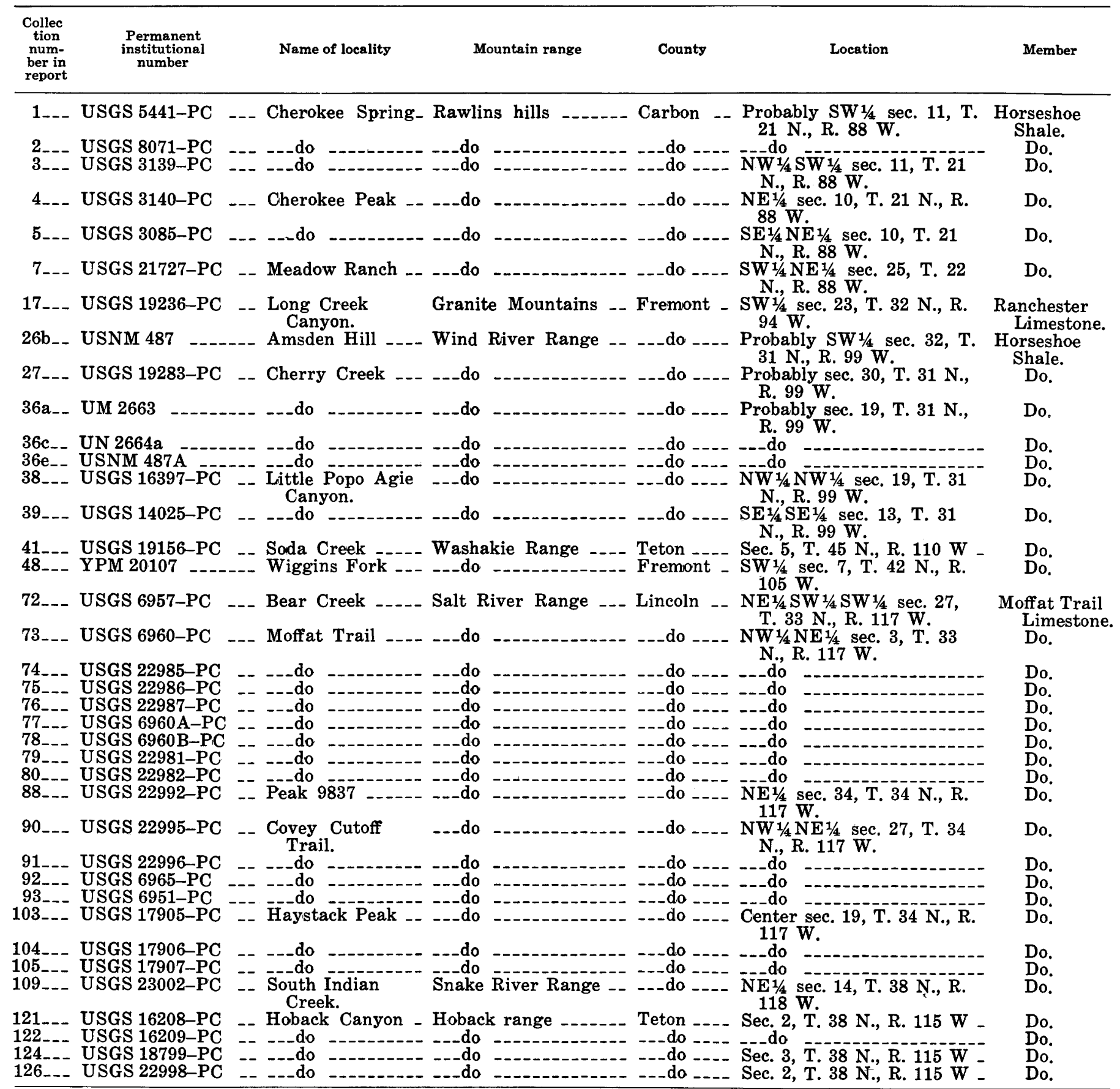

The coelenterate faunas of the Horseshoe and Ranchester Members are too meager and too poorly known to be of much value in correlation of these parts of the Amsden Formation. Barytichisma amsdenense (Branson and Greger), from the Mississippian part of the Horseshoe, is unknown outside of the Amsden and is the first Mississippian species to be assigned to the genus Barytichisma, which was previously known only from beds of Early Pennsylvanian age. Neokoninckophyllum hamatilis $\mathrm{n}$. sp. and $N$. inconstans n. sp., from the Pennsylvanian part of the Horseshoe Member, are also known only from the Amsden Formation; other described species of Neokoninckophyllum in North America range through most of the Pennsylvanian. The only coelenterate found in the Ranchester Member is a poorly preserved species of Chaetetes most similar to Chaetetes eximius Moore and Jeffords from the Early Pennsylvanian of Texas and Oklahoma. 
The coelenterate fauna of the Moffat Trail Limestone Member offers a more fruitful basis for correlation. Most of the described species in this fauna have been found elsewhere in the western United States in the Caninia Zone, also known as Zone $\mathrm{K}$ in the biostratigraphic scheme of Sando, Mamet, and Dutro (1969). This zone has been correlated by means of Foraminifera with the middle and upper parts of the Chesterian Series of the midcontinent region and with the latest Visean $\left(\mathrm{V} \mathrm{c}_{\mathrm{s}}\right)$ and early Namurian $\left(\mathrm{E}_{1}\right.$ and $\left.\mathrm{E}_{2}\right)$ of Europe. Characteristic of Zone $\mathrm{K}$ are the large cyathopsid corals allocated to Caninia nevadensis (Meek) and the related species $C$. excentrica (Meek), C. enormis Easton, and C. montanensis Easton which are known elsewhere from the Surrett Canyon Formation and Monroe Canyon Limestone of Idaho, the Big Snowy Group of southwest and central Montana, the upper parts of the Great Blue Limestone and Green Ravine Formation of central Utah, and the Ochre Mountain Limestone and Chainman Shale of western Utah. Zone $\mathrm{K}$ is also characterized by a proliferation of distinctive syringoporoid corals. Among the Moffat Trail representatives of this group is Duncanopora duncanae n. sp., a species known from the Surrett Canyon Formation and Monroe Canyon Limestone of Idaho and the Green Ravine Formation of Utah. Pleurosiphonella drummondi (Nelson), another Moffat Trail syringoporoid, occurs in the upper part of the Etherington Formation of western Canada. Another characteristic Zone $\mathrm{K}$ coral is Lonsdaleia (Actinocyathus) stelcki (Nelson), which occurs in the Surrett Canyon Formation and Monroe Canyon Limestone of Idaho, the Green Ravine Formation of Utah, and the Etherington Formation of western Canada. Zone $\mathrm{K}$ coelenterates not certainly known outside of the Moffat Trail Limestone Member of the Amsden are Chaetetes wyomingensis n. sp., Multithecopora? amsdenensis n. sp., and Turbinatocaninia? sp.

The classification of the chaetetid hydrozoans followed in this paper is taken from Sokolov (1950, 1955). The Rugosa are classified according to Hill (1956). Tabulates are regarded as an order, following Hill and Stumm (1956), but the families are taken from Sokolov (1962).

Morphologic terminology follows that of Hill (1956) and Hill and Stumm (1956) with the exception of the terms "alar diameter" and "calicular angle," which were defined by Sando (1961). The terminology of microstructural elements is that of Kato (1963). In descriptions of solitary corals where the terms "left" and "right" are used, these terms are in reference to the cardinal-counter plane when the corallum is viewed from below with the cardinal septum oriented toward the observer. Photographs and drawings of serial transverse thin sections of solitary corals are oriented so as to be looking up the corallum axis toward the calice and the cardinal septum is toward the bottom of the plate.

Specimens studied are in the collections of the U.S. National Museum, Washington, D.C. (USNM), the Department of Geology, University of Missouri, Columbia, Mo., (UM), and the Peabody Museum of Natural History, Yale University, New Haven, Conn., (YPM). Detailed locality data are given in the Register of Amsden Fossil Collections in Sando, Gordon, and Dutro, 1974.

I am indebted to the late Helen Duncan for technical review of the manuscript and particularly for her advice concerning the taxonomy of the Chaetetidae. Thanks are also extended to W. A. Oliver, Jr., for his review of the manuscript. Thin sections were prepared by K. R. Moore, and photographs were made by D. H. Massie (thin sections) and R. H. McKinney (exteriors).

\section{SYSTEMATIC PALEONTOLOGY}

\author{
Phyllum COELENTERATA \\ Class HYDROZOA \\ Group CHAETETIDA \\ Family CHAETETIDAE
}

Discussion.-Among the most interesting of the Amsden fossils are the colonial organisms classified as chaetetids. Although the taxonomic position of this poorly known group was doubtful for many years, Sokolov $(1950,1955)$ has presented convincing arguments for interpreting it as an ancient member of the Class Hydrozoa and has pioneered in the discrimination and description of genera. Accordingly, the classification and morphological terminology used by Sokolov are followed in this paper.

Because of their similarity to the Bryozoa, an appreciable number of bryozoan species were formerly allocated to the chaetetids. Aside from these, the valid North American record of the Chaetetidae is almost exclusively Pennsylvanian, in fact so overwhelmingly so that the group, and particularly the genus Chaetetes, has been regarded generally as an index to beds of Pennsylvanian age in North America. However, rare Mississippian occurrences were recorded by Stouder (1938, p. 284) and H. M. Duncan (in U.S. Geological Survey, 1965, p. A122; 1966, p. A112) in the Chester Series of Kentucky. Moreover, the worldwide range of the group is from Ordovician to Miocene (Sokolov, 1955, p. 95), and 
the Chaetetidae are common throughout the Carboniferous in Europe (Sokolov, 1939, p. 411). It is not surprising, therefore, to find this group represented in both the Mississippian and Pennsylvanian parts of the Amsden Formation.

The identifiable Amsden forms are all allocated to the genus Chaetetes Fischer. Two species, both similar to Chaetetes milleporaceus Milne-Edwards and Haime, are recognized in the Amsden material, one in the Mississippian part and the other in the Pennsylvanian part of the formation.

Chaetetiform trepostomatous bryozoans occur sparingly in the Moffat Trail Member of the Amsden along with Chaetetes wyomingensis $\mathrm{n}$. sp. These bryozoans formed spherical or hemispherical colonies of size comparable to that of the Chaetetes, are composed of polygonal to rounded-polygonal tubes of comparable diameters, and have horizontal partitions similar to the tabulae of Chaetetes. Although the bryozoans are not formally described in this paper, it seems desirable to point out features by which they may be distinguished from the chaetetids (compare plates 1 and 2):

1. The wall structure of the bryozoans is laminar, as compared to the trabecular wall structure of the chaetitids.

2. The walls of the bryozoans are thinner $(0.01$ to $0.03 \mathrm{~mm}$, average about $0.02 \mathrm{~mm}$ ) than those of the Amsden Chaetetes.

3. The bryozoans are composed of tubes of two distinct sizes (smaller ones are acanthopores or mesopores), whereas the Amsden Chaetetes have tubes of relatively uniform diameter.

4. The bryozoans lack pseudosepta. Reproduction is by fission in which vertical partitions arise from the floors of horizontal partitions so that the vertical partitions are always complete in transverse section. In Chaetetes, vertical partions arise from one or more sides of the walls of the tubes so that many are incomplete in transverse section.

Genus CHAETETES Fischer von Waldheim in Eichwald, 1829

Chaetetes wyomingensis n. sp.

Plate 1, figures 1-3

Description.-Colony seemingly regularly or irregularly spherical or hemispherical, composed of radially diverging cells. The largest colonies (including holotype) were at least $6 \mathrm{~cm}$ high and $13 \mathrm{~cm}$ in diameter; most of the specimens are fragments of smaller size than this, and the actual size of the colonies was probably considerably larger than the largest measured specimen. The specimens are all composed of partly silicified, moderately to strongly recrystallized calcite.

In transverse section (pl. 1, fig. 1), the cross sections of cells are polygonal, mostly hexagonal, but rarely quadragonal or pentagonal. They are equidimensional to elongate, but not meandroid, and fairly uniform in diameter. Visceral spaces are angular to rounded. Cell walls are straight and unbeaded. Wall microstructure is faintly trabecular (pl. 1, fig. 3). Maximum diameter of the visceral space ranges from 0.12 to $0.45 \mathrm{~mm}$; the average per colony ranges from 0.28 to $0.35 \mathrm{~mm}$ (table 3 ). Minimum diameter of the visceral space ranges from 0.11 to $0.42 \mathrm{~mm}$; the average per colony ranges from 0.23 to $0.29 \mathrm{~mm}$ (table 3). Wall thickness ranges from 0.02 to $0.05 \mathrm{~mm}$; the average per colony ranges from 0.30 to $0.36 \mathrm{~mm}$ (table 3 ). Pseudosepta are common, present in about 10 to 20 percent of the cells. Fission is mostly bipartite, rarely tri- or quadripartite; all stages of fission are commonly visible.

In longitudinal section (pl. 1, fig. 2), the cells appear as straight to slightly sinuous tubes that have generally parallel walls except where fission has taken place. There is some evidence for fission being more common at some levels of the colony than at others. Evidence of complete fission is rare. Tabulae are mostly complete, that is, their traces ordinarily extend uninterruptedly from one side of the wall to the other; incomplete traces apparently are the result of poor preservation. Tabulae are horizontal and flat to very slightly concave upward. Tabular thickness is approximately $0.01 \mathrm{~mm}$ but is difficult to measure owing to difficulty in differentiating true tabular structure from crystalline overgrowths. Tabulae in adjacent cells may or may not be coincident in position; the majority are noncoincident. Tabular spacing is generally relatively constant from one cell to another in a given colony. Although some colonies exhibit nontabulate zones of 1 or $2 \mathrm{~mm}$ thickness, these do not persist throughout the colony and appear to be a function of preservation. The average tabular frequency is about four tabulae per $\mathrm{mm}$ and is relatively constant from one colony to another. Individual tabulae are ordinarily spaced 0.10 to $0.77 \mathrm{~mm}$ apart.

Discussion.-Chaetetes wyomingensis is the first true Chaetetes to be described from the Mississipian rocks of North America. Its occurrence in the Amsden Formation is confined to the Caninia Zone of the Moffat Trail Member in western Wyoming. Foraminifera in three of the five collections are indicative of Foraminiferal Zones 17 or 18, an interval of early Namurian $\left(\mathrm{E}_{1}-\mathrm{E}_{2}\right)$ age. 
TABLE 3.-Measurements (in $\mathrm{mm}$ ) of Chaetetes wyomingensis $n$. sp. in transverse section

[Each parameter is represented by 20 measurements per specimen]

\begin{tabular}{lccccccc}
\hline \multirow{2}{*}{$\begin{array}{c}\text { USNM } \\
\text { specimen } \\
\text { number }\end{array}$} & \multicolumn{2}{c}{$\begin{array}{c}\text { Maximum diameter } \\
\text { of visceral space }\end{array}$} & \multicolumn{2}{c}{$\begin{array}{c}\text { Minimum diameter } \\
\text { of visceral space }\end{array}$} & \multicolumn{2}{c}{ Wall thickness } \\
\cline { 2 - 8 } & Range & Average & Range & Average & Range & Average \\
\hline 165082 & -- & $0.22-0.44$ & 0.33 & $0.21-0.42$ & 0.29 & $0.02-0.05$ & 0.036 \\
165081 & -- & $.17-.45$ & .30 & $.15-.30$ & .23 & $.02-.05$ & .034 \\
165083 & -- & $.22-.45$ & .35 & $.15-.38$ & .27 & $.03-.04$ & .035 \\
165084 & -- & $.21-.38$ & .30 & $.15-.30$ & .23 & $.02-.04$ & .030 \\
165080 & -- & $.12-.34$ & .28 & $.11-.29$ & .23 & $.02-.05$ & .032 \\
& & & & & & &
\end{tabular}

Comparison with other North American species is based on descriptions and illustrations of a topotype of Chaetetes milleporaceus Milne-Edwards and Haime (Middle Pennsylvanian of Indiana) published by Lane and Martin (1966) and of three species from the Lower Pennsylvanian of Texas and Oklahoma by Moore and Jeffords (1945). Chaetetes wyomingensis is similar to $C$. milleporaceus in the average diameter of its visceral spaces and in its average tabular frequency but is readily distinguished by its thinner cell walls (about $0.03 \mathrm{~mm}$ vs. $0.065 \mathrm{~mm}$ in C. milleporaceus) and its relatively abundant pseudosepta. Moreover, C. milleporaceus formed lenticular colonies whereas $C$. wyomingensis appears to have formed large spherical or hemispherical colonies.

The new Amsden species is also readily differentiated from $C$. eximius, $C$. favosus, and $C$. subtilis (all described by Moore and Jeffords, 1945, p. 191$195)$ on the basis of its thinner cell walls. C. eximius and $C$. favosus have about the same average visceral space diameter as $C$. wyomingensis, but the Pennsylvanian species have beaded walls. $C$. subtilis has straight walls but has a smaller visceral space diameter. Pseudosepta are rare in $C$. favosus and $C$. subtilis. Tabulae are also rare and commonly incomplete in these two species, but preservation may be a factor in this feature. Tabular frequency in $C$. eximius is greater than that of $C$. wyomingensis.

Occurrence and abundance.-Moffat Trail Limestone Member: collections 72(2), 77(1), 78(1), $79(2+), 80(1)$, Lincoln County, Wyo.

Specimens.-Holotype, USNM 165080 ; paratypes, USMN 165081-84.

\section{Chaetetes cf. C. eximius Moore and Jeffords Plate 1, figures 4-7}

Description.-Colony seemingly large, massive, exact form unknown, composed of radially diverging cells. The species is known from one completely silicified specimen that was at least $5 \mathrm{~cm}$ high and $10 \mathrm{~cm}$ in diameter.
In transverse section (pl. 1, fig. 6), the cross sections of cells are polygonal, mostly hexagonal, but rarely quadragonal or pentagonal. They are equidimensional to elongate, but not meandroid, and fairly uniform in diameter. Visceral spaces are angular to rounded. Cell walls are straight and unbeaded. Wall microstructure is obscure but seemingly trabecular (pl. 1, fig. 4). Maximum diameter of the visceral space ranges from 0.20 to $0.44 \mathrm{~mm}$; the average per colony is 0.33 . Minimum diameter of the visceral space ranges from 0.16 to $0.33 \mathrm{~mm}$; the average per colony is 0.26 . Wall thickness ranges from 0.04 to $0.7 \mathrm{~mm}$; the average per colony is 0.055 . Pseudosepta are very rare in some sections and common (visible in 10 to 20 percent of the cells) in others. Where present, fission is mostly bipartite but may be tri- or quadripartite; all stages of fission may be seen.

In longitudinal section (pl. 1, figs. 5, 7), the cells appear as straight to slightly sinuous tubes that have generally parallel walls. Evidence of complete fission is rare. Tabulae are extremely rare in most sections, probably owing to poor preservation. They are complete or incomplete, mostly horizontal, and flat to very slightly concave upward. In well-preserved parts of the colony, the tabulae are spaced 0.10 to $0.30 \mathrm{~mm}$ apart, and the average tabular frequency is about six or seven tabulae per $\mathrm{mm}$.

Discussion.-This species is based on a single completely silicified specimen from the Ranchester Member and is of Pennsylvanian age. Because the poor preservation of the material leaves some doubt as to the frequency of the tabulae, it does not seem advisable to give this species a new name.

Chaetetes cf. C. eximius is similar to C. wyomingensis in visceral space diameter, cell shape, and apparently in the form of the colony, but it is readily distinguished by its thicker cell walls. Moreover, where tabulae are preserved, the average tabular frequency is greater in the Pennsylvanian form.

The Amsden species seems most similar to Chaetetes eximius Moore and Jeffords (1945, p. 191, figs. 207,208 ) but has straight instead of beaded walls and has slightly thicker walls. Its cells are larger than those of $C$. subtilis Moore and Jeffords (1945, p. 194, figs. 211a-d), and it has more numerous pseudosepta than that species. It is distinguished from C. favosus Moore and Jeffords (1945, p. 193, figs. 209, 210) by its straight walls, more numerous pseudosepta, and slightly thicker walls. It differs from C. milleporaceus Milne-Edwards Haime (see Lane and Martin, 1966) in having slightly thicker walls, more numerous pseudosepta, and a greater tabular frequency. 
Occurrence and abundance.-Ranchester Limestone Member: collection 17(1), Fremont County, Wyo.

Specimen.-Figured, USNM 165085.

\section{Chaetetes sp. indet.}

1918. Chaetetes? Branson and Greger, p. 313, pl. 19, figs. 21, 22.

1937. Chaetetes? sp. Branson, p. 652.

Description.-Two fragmentary, completely silicified specimens approximately $4 \mathrm{~mm}$ high by $4 \mathrm{~mm}$ in diameter cannot be assigned to any known species owing to poor preservation of internal structures. The general morphology of these specimens is essentially the same as that of the two species described previously in this report. As in $C$. cf. $C$. eximius, evidence of fission is rare and tabulae are rare, probably as the result of silicification. Visceral space diameters are within or close to the ranges of both species previously described; maximum diameter ranges from 0.20 to $0.39 \mathrm{~mm}$ and averages $0.28 \mathrm{~mm}$, whereas minimum diameter ranges from 0.14 to $0.31 \mathrm{~mm}$ and averages $0.22 \mathrm{~mm}$, as measured in one specimen (UM 2664). Wall thickness is close to that of $C$. cf. C. eximius, ranging from 0.04 to $0.07 \mathrm{~mm}$ and averaging $0.056 \mathrm{~mm}$ (UM 2664).

Morphologically, the species seems to be closer to $C$. cf. C. eximius from the Ranchester Member in central Wyoming rather than C. wyomingensis from the Moffat Trail Member of western Wyoming. However, crude preservation of internal structures by silicification leaves doubt concerning wall thickness and number of tabulae.

Occurrence and abundance.-Horseshoe Shale Member: collections 26b (1), 36c (1), Fremont County, Wyo.

Specimens.-Unfigured, USNM 487 and UM 2664.

Class ANTHOZOA
Subclass ZOANTHARIA
Order RUGOSA
Suborder STREPTELASMATINA
Superfamily CYATHAXONIICAE
Family AMPLEXIDAE
Genus AMPLEXUS Sowerby, 1814
"Amplexus" sp. indet.
Plate 3, figures 26-29

Description.-This category includes five specimens, four of which appear to be immature forms, from a single locality. The largest specimen in the lot is the one illustrated on plete 3. This specimen is about $28 \mathrm{~mm}$ long and attains a maximum diameter of $14 \mathrm{~mm}$, at which there are 26 short major septa. Minor septa are absent. The corallum is cylindrical and slightly curved, and the cardinal septum is on the concave side of the corallum. Serial transverse sections (pl. 3, figs. 26-29) suggest that the early part of the corallum (up to a diameter of about $9 \mathrm{~mm}$ ) is characterized by a zaphrentoid septa plan like that of the genus Zaphrentites Hudson. Later sections are characterized by amplexoid retreat of the major septa. Tabulae appear to be more or less flat and complete, downturned at the margins and depressed in the cardinal fossula. Dissepiments are absent.

Discussion.-Easton (1962, p. 31) pointed out that the genus Amplexus has been so broadly applied as to include corals of uncertain phylogenetic relationship. Hill (1940, p. 147-148) also suggested that the group is probably polyphyletic. Moreover, the early stages of the type species are unknown, and until that is determined, species cannot be assigned to Amplexus with any degree of certainty. Easton (1962, p. 31) erected the genus Fasciculiamplexus, based on a species whose early stages are known, as a partial solution to this nomenclatural problem. According to Easton, Fasciculiamplexus may have developed from Fasciculophyllum Thomson by continuation of an amplexoid trend. Although the Amsden coral here provisionally called " $A m$ plexus" has many features in common with Fasciculiamplexus, its cardinal fossula is on the concave side of the corallum, rather than on the convex side as in Easton's genus. I am therefore reluctant to refer it to Fasciculiamplexus. Because the Amsden material is meager and generally poorly preserved, it is impractical to base a new genus on it; hence the old designation "Amplexus" is retained.

Occurrence and abundance.-Horseshoe Shale Member: collection 41 (5), Teton County, Wyo.

Specimens._USNM 165088.

\section{Family HAPSIPHYLLIDAE Genus ZAPHRENTITES Hudson, 1941 Zaphrentites? sp. indet.}

This category includes four small, imperfectly preserved horn corals that have a simple zaphrentoid septal plan and cardinal fossula on the concave side of the corallum. The largest specimen is about $30 \mathrm{~mm}$ long and attains a maximum diameter of about $15 \mathrm{~mm}$, at which there are 27 major septa. In the absence of better material, it is impossible to determine whether these specimens represent the mature stages of Zaphrentites or are merely immature stages of amplexoid corals such as "Amplexus" or Barytichisma.

Occurrence and abundance.-Moffat Trail Limestone Member: Collections 76(1), Lincoln County; $121(2)$, Teton County. Horseshoe Shale Member: Collection 48(1), Fremont County, Wyo.

Specimens.-USNM 165089, 165090; YPM 2010. 
Genus BARYTICHISMA Moore and Jeffords, 1945

Barytichisma amsdenense (Branson and Greger)

Plate 3, figures 1-25

1918. Zaphrentis amsdenensis Branson and Greger, p. 313, pl. 19, figs. 19, 20.

1937. Zaphrentis amsdenensis Branson and Greger. Branson, p. 652.

1950. Zaphrentis amsdenensis Branson and Greger. Bassler, p. 220.

Diagnosis.-Solitary, moderately curved, trochoid to ceratoid corals that have a cardinal septum on the concave side of the corallum. Corallum as much as $50 \mathrm{~mm}$ in length and $23 \mathrm{~mm}$ in maximum diameter and having as many as 38 major septa at maturity. Calice moderately deep and having a slightly depressed floor. Exterior marked by prominent septal grooves and interseptal ridges and transverse wrinkles and fine growth lines. Theca thick. In young stages, major septa axially confluent and grouped in quadrants that are marked by a well-defined cardinal fossula, alar pseudofossulae, and less readily identified counter septum. Ephebic stage characterized by amplexoid retreat of major septa on upper surfaces of tabulae. Minor septa absent. Tabulae mostly complete, more or less horizontal, but bent downward marginally, and deeply depressed in cardinal fossula. Dissepiments absent. Septal microstructure of the feather type of Kato (1963).

Description of lectotype.-The type lot (UM 2663) consists of six free coralla of yellowish calcite preservation evidently collected from float. The largest specimen in the lot is chosen as the lectotype; this specimen appears to be the one illustrated by Branson and Greger, although their illustrations are not clear enough to be certain.

The lectotype (pl. 3, figs. 1-18) is a nearly perfect specimen, lacking only the walls of the calice, which were broken off down to the floor of the calice. The corallum is $50 \mathrm{~mm}$ long and attains a maximum diameter of $23 \mathrm{~mm}$. The corallum is trochoid, moderately curved, and has an apicai angle of about $44^{\circ}$ and a calicular angle of about $16^{\circ}$. The cardinal septum is on the concave side of the corallum and is located slightly to the left of the plane of curvature. The transverse section of the corallum is approximately circular throughout the growth. The broken calice (pl. 3, fig. 15) reveals 38 major septa that exend from the periphery one-half to two-thirds of the radius on the axially-depressed tabular floor of the calice. The cardinal septum is reduced to a low ridge at the end of a parallel-sided fossula that has a depressed floor. No minor septa are present. Longitudinal ornamentation consists of broad, slightly elevated interseptal ridges 1 to $1.5 \mathrm{~mm}$ wide in the mature parts of the corallum. Transverse or- namentation consists of growth wrinkles 2 to $4 \mathrm{~mm}$ apart and finer growth lines. The exterior has been modified by solution weathering so that all ornamentation is subdued.

Ontogeny in the lectotype was studied by means of 14 serial transverse sections (table 4 ; pl. 3 , figs. 1-14). Seven thin sections were cut at intervals of approximately $5 \mathrm{~mm}$ beginning at a level just below the floor of the calice down to a level $6.3 \mathrm{~mm}$ above the tip. The remaining, earliest part of the specimen was studied by the serial peel technique described by Sando (1967).

The obvious lack of a significant part of the counter side of the corallum, probably due to solution weathering, seriously limited the completeness of observations made in the earliest $4.3 \mathrm{~mm}$ of the specimen. The earliest section studied (table 4 , section $n$; pl. 3, fig. 1) revealed only the cardinal septum, two alar septa, and a cardinal lateral septum, but it seems probable that the counter and one or more counter lateral septa were also present at this stage. Moreover, the very earliest part of the corallum (brephic stage) does not seem to have been preserved. Section i (table 4; pl. 3, fig. 6) is the first stage at which septal complements in the counter quadrants appear to be trustworthy. Acceleration in the counter quadrants, which marks the later stages, was first noted in this section.

In the absence of a section in which only the protosepta are present, no brephic stage is recognized in the lectotype. The neanic stage (table 4, sections $f$ to $n$; pl. 3, figs. 1-9) is characterized by a well-defined cardinal fossula that contains a cardinal septum of variable length and thickness and by axially confluent major septa. The neanic stage is recognized up to an alar diameter of $12 \mathrm{~mm}$ and a complement of 28 major septa. Section e (table 4 ; pl. 3, fig. 10) records the earliest noted appearance of the mature characters of the corallum (ephebic stage). The alar diameter is $14.5 \mathrm{~mm}$, and the corallum contains 34 major septa at this level. The ephebic stage is characterized by amplexoid retreat of the major septa, a very short cardinal septum, and a peripheral stereozone 1.5 to $2.5 \mathrm{~mm}$ thick. Minor septa are absent in all growth stages. The septal microstructure is the feather type of Kato (1963). Tabular traces are visible in all late neanic and ephebic transverse sections beginning with section $\mathrm{h}$ (table 4 ; pl. 3, fig. 7), but the nature of the tabulae was not studied in longitudinal section.

Description of other specimens.-Superficial examination of paralectotypes, topotypes, and other specimens revealed a morphology similar to that of 
TABLE 4.-Ontogeny in the lectotype (UM 2663) of Barytichisma amsdenense (Branson and Greger). Brephic stage seemingly not preserved

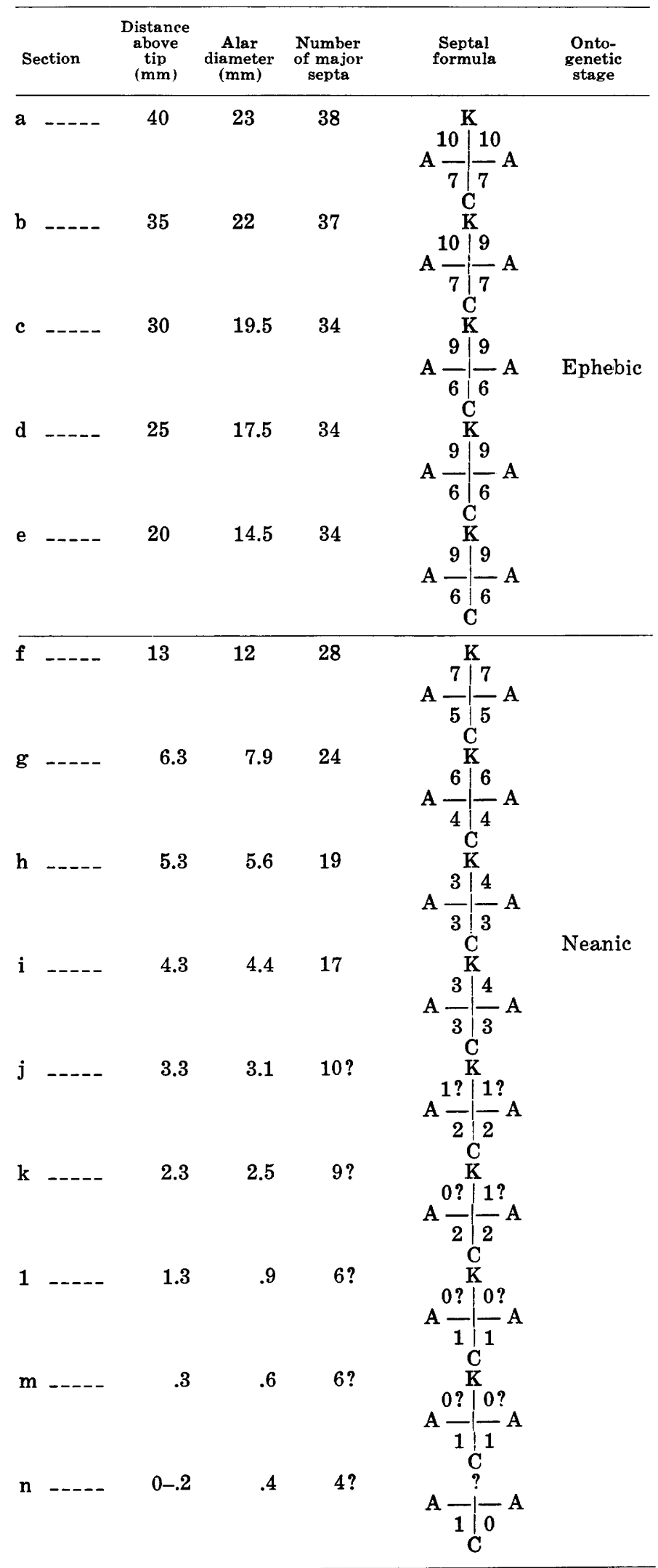

the lectotype. Although a few specimens have nearly straight conical coralla, the dominant corallum form is a slightly curved cone. The specimens range from 8 to $45 \mathrm{~mm}$ in length and 11 to $21 \mathrm{~mm}$ in maximum diameter; all but two of the specimens are incomplete. The cardinal septum is invariably on the concave side of the corallum, mostly in the plane of curvature or slightly to one side, but rarely close to the alar plane. Calicular angles range from $15^{\circ}$ to $40^{\circ}$ (average $21.9^{\circ}$ ) and apical angles range from $25^{\circ}$ to $48^{\circ}$ (average $37^{\circ}$ ). Except where abraded or corroded, the exteriors are marked by rather strong longitudinal ribbing and transverse wrinkles and fine growth lines. Septal complements at various growth stages are shown in figure 1.

One of the topotypes (USNM 165091), a neanic specimen about $20 \mathrm{~mm}$ long and $12 \mathrm{~mm}$ in maximum diameter, was serially sectioned (table 5 ; pl. 3 , figs. 20-25) in order to study early growth stages that are unreliably represented in the lectotype. The earliest part of the tip was not preserved on this specimen, but a four-septum stage (pl. 3, fig. 20) represents the brephic part of the corallum.

A thin section of one of the paralectotypes (UM 2663 ; pl. 3, fig. 19) illustrates features of the species seen in longitudinal section. The tabulae are mostly complete, flat to sagging, and slightly inclined cardinally. Their margins are reflexed downward. Dissepiments are absent.

Discussion.-Species previously assigned to the genus Barytichisma are exclusively Early Pennsylvanian. These include $B$. crassum, $B$. repletum, and B. callosum, described by Moore and Jeffords (1945, p. 131-137) from formations of Morrowan age in Texas and Arkansas, and B. zaphrentiforme (White), redescribed by Sando (1965, p. E7-E11) from the Morgan Formation of Atokan age in Colorado. Although Barytichisma amsdenense seems most closely allied to $B$. callosum and $B$. zaphrentiforme by virtue of its cardinal septum on the concave side of the corallum, it differs significantly from both of these Pennsylvanian species. B. callosum has a cylindrical rather than curved conical corallum, a larger number of major septa at comparable corallum diameters, and more numerous tabulae than $B$. amsdenense. $B$. zaphrentiforme is considerably larger than $B$. amsdenense, has a much thicker theca, and does not have the coarse external ribbing of the Amsden species. $B$. amsdenense and $B$. zaphrentiforme have a similar ontogeny and septal complement at comparable corallum diameters, but the latter has a greater septal number at maturity.

Barytichisma amsdenense is known only from a relatively small area in the southern Wind River 
Range that includes the Cherry Creek, Amsden Hill, and Little Popo Agie River localities. Its exact stratigraphic position is in doubt because all the specimens were collected from float. However, it occurs with fossils characteristic of the late Chesterian Anthracospirifer welleri-shawi Zone at all localities. In three of the collections $(26 \mathrm{~b}, 36 \mathrm{a}, 39)$ it occurs with fossils representative of both the Composita poposiensis Subzone and the Carlinia amsdeniana Subzone. In two collections $(36 e, 38)$ it occurs with fossils representative of the Composita poposiensis Subzone. It occurs exclusively with Carlinia amsdeniana Subzone fossils in only one collection (27). The known distribution suggests that $B$. amsdenense is restricted to the Composita poposiensis Subzone and that its occurrence with fossils of the Carlinia amsdeniana Subzone at some localities is accidental.

Occurrence and abundance.-Horseshoe Shale Member: collections 26b(2?), 27(16), 36a(6), $36 \mathrm{e}(2), 38(11), 39(2)$, Fremont County, Wyo.

Specimens.-Lectotype and paralectotypes UM2663; topotypes USNM 165091, 165092; other specimens USNM 487, 487A, 165093, 165094.

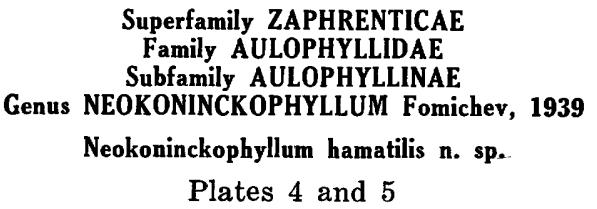

Diagnosis.-Solitary corals having a conical neanic stage and a cylindrical ephebic stage. Corallum as much as $75 \mathrm{~mm}$ or more in length and 40 $\mathrm{mm}$ in maximum diameter and having as many as 65 major septa at maturity. Exterior marked by subdued interseptal ridges and narrow septal grooves and subdued rugae and fine growth lines.

Corallum supported by talons in early stages. Rejuvenation common. Theca thin. Septal plan pinnate in brephic and early neanic stages but radial in later stages. Cardinal septum long, on convex side of corallum in conical stage, and in a poorly defined fossula. Minor septa very short. Neanic axial structure consisting of a medial plate oriented in the cardinal-counter plane and continuous with cardinal and counter septa, periaxial tabellae and tabulae, and a few septal lammellae; medial plate free, very thin, sinuous, and discontinuous and septal lamellae poorly developed in ephebic stage. Tabularium marked by a marginal septal stereozone and horizontal inflated tabulae. Dissepimentarium characterized by as many as 13 rows of steeply inclined regular and herringbone dissepiments and rare lonsdaleoid dissepiments. Septal microstructure of the diffusotrabecular type of Kato (1963).
TABLE 5.-Ontogeny in a topotype (USNM 165091) of Bary. tichisma amsdenense (Branson and Greger)

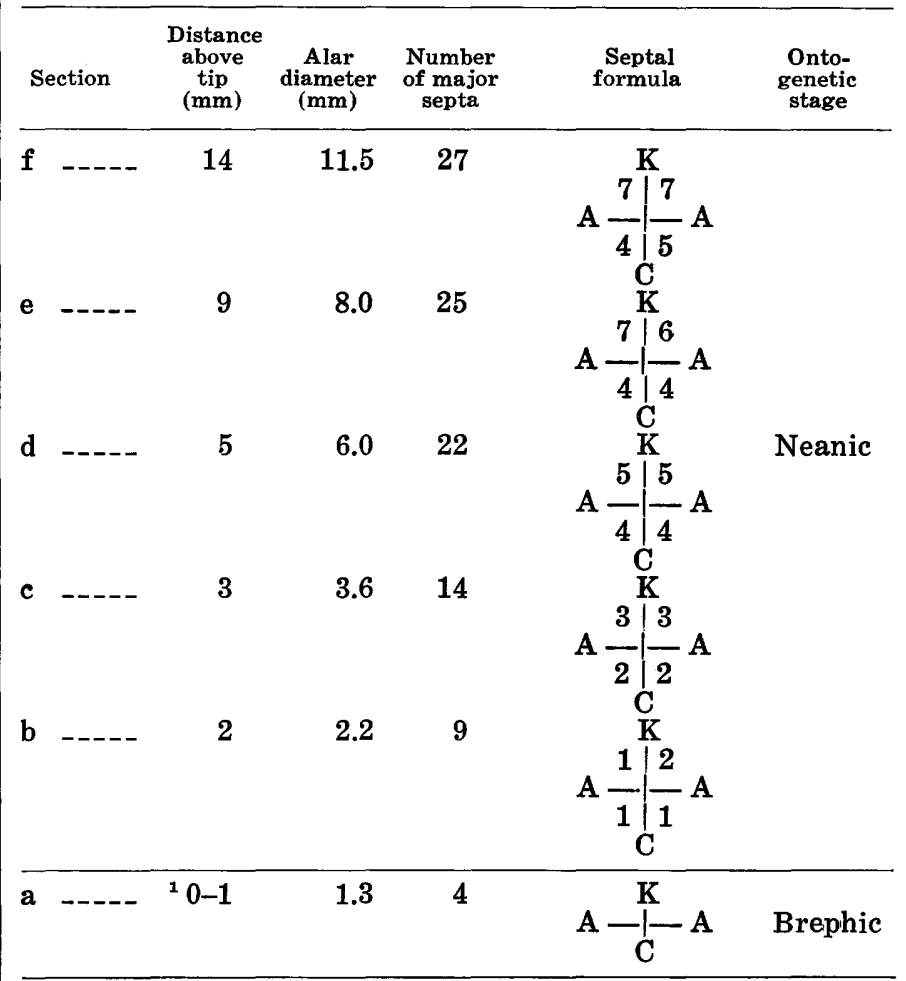

${ }^{1}$ Actual tip broken off.

Description of holotype.-The holotype (USNM 165095 ; pl. 4) is a perfect specimen except for some decortication in the lower part of the corallum. The corallum is a gently curved cone about $55 \mathrm{~mm}$ long and $35 \mathrm{~mm}$ in maximum diameter. The calicular angle is between $25^{\circ}$ and $30^{\circ}$. The lower $10 \mathrm{~mm}$ of the corallum is strongly curved and has the cardinal septum on the convex side, approximately in the plane of curvature. Above the lower $10 \mathrm{~mm}$, the plane of curvature rotates through an angle of about $30^{\circ}$ from its earlier position so that the cardinal position, although still located on the convex side of the corallum, is about $30^{\circ}$ to the left of the plane of curvature when the corallum is viewed from below. Approximately $10 \mathrm{~mm}$ above the tip, the entire left side of the corallum is extended outward to form a supporting structure or talon; the lateral surface of the talon is extensively and deeply crenulated. Although the calice is covered with matrix, it appears to be only about $10 \mathrm{~mm}$ deep. The exterior of the corallum is marked longitudinally by broad, subdued interseptal costae and narrow septal grooves. Transverse ornamentation consists of subdued rugae and fine growth lines. One episode of rejuvenation is recorded $20 \mathrm{~mm}$ above the tip.

The internal morphology of this specimen was studied by means of seven transverse thin sections 
cut from the upper part of the corallum (pl. 4, figs. 9-15) and eight transverse peels made from the lower $4.5 \mathrm{~mm}$ (pl. 4, figs. 1-8). No longitudinal sections were made. Distance above tip, alar diameter, number of major septa, septal formula, and ontogeneric stage for each of these sections are recorded in table 6 . The relation between number of major septa and alar diameter in various sections is compared with similar data from paratypes in figure 2.

The brephic stage (table 6, sections a and b; pl. 4, figs. 1, 2), characterized by the development of the six protosepta (cardinal, counter, two alars, and two counter laterals), occupies the lower $0.4 \mathrm{~mm}$ of the corallum. The earliest section studied, cut within $0.1 \mathrm{~mm}$ of the preserved tip, revealed a twochambered cup partitioned by a single septum (pl. 4, fig. 1). Serial studies indicate that this septum later differentiated into the cardinal and counter septa. In the interval 0.1 to $0.2 \mathrm{~mm}$ above the tip, the chamber to the right of the initial septum was closed by skeletal deposits, whereas the left-hand chamber remained open. Differentiation of the nextformed septa were observed within the skeletal deposits forming the thecal wall in the interval 0.2 to $0.4 \mathrm{~mm}$ above the tip. The alar and two counter lateral septa began to differentiate approximately simultaneously. At first the protosepta were buried in the wall of the primitive cup (pl. 4, fig. 2); higher in the corallum, but still less than $0.4 \mathrm{~mm}$ above the tip, open spaces developed between the septa, and the large open space became the loculus between the left alar septum and the left counter lateral septa (pl. 4, fig. 3).

The neanic stage (table 6 , sections c-k; pl. 4, figs. $3-11$ ) is defined as the period of growth that began with insertion of the metasepta about 0.4 to 0.5 $\mathrm{mm}$ above the tip and ended about $20 \mathrm{~mm}$ above the tip, where the rate of diameter increase appears to have diminished significantly (fig. 3). The total major septal complement at the end of the neanic stage was about 40 to 47 . The septal plan was

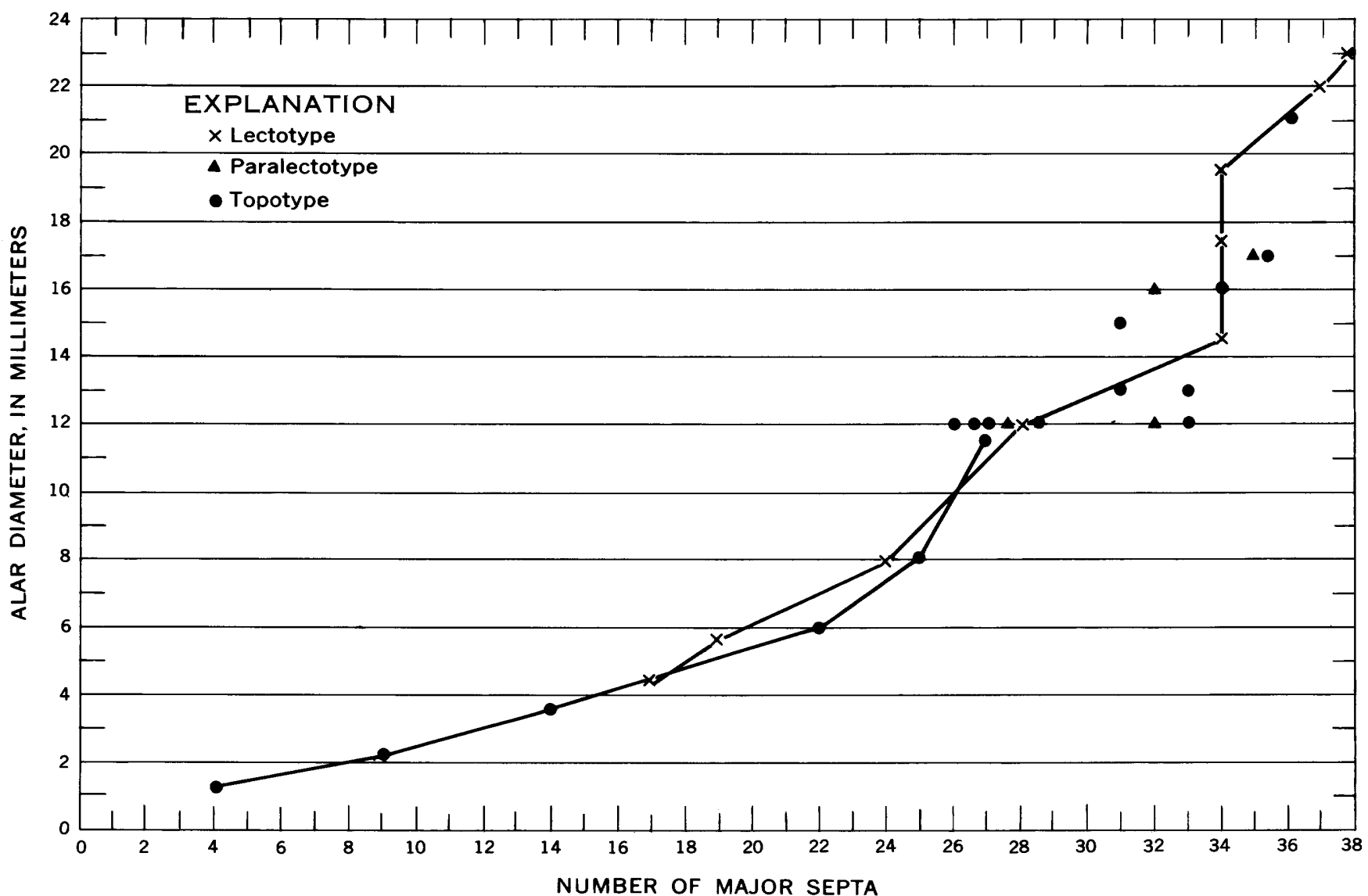

FIGURE 1.-Scatter diagram showing relation between alar diameter and number of major septa by means of 30 measurements on 16 specimens of Barytichisma amsdenense (Branson and Greger). Straight lines connect measurements made from serial sections of lectotype (UM 2663) and a topotype (USNM 165091). 
moderately pinnate and had relatively well defined insertion positions up to about $3.5 \mathrm{~mm}$ above the tip (pl. 4, figs. 3-7), after which the plan tended to be radial, and had poorly defined insertion positions (particularly the alar positions). As a radial plan developed, the major septa became narrowly wedge shaped and withdrew from the axial region (pl. 4, figs. 9-11). The septa were uniformly dilated in the early neanic sections (pl. 4, figs. 3-8), but dilation moved inward and was confined to the tabularium after development of the dissepimentarium (pl. 4, figs. 9-11). Insertion of major septa in the cardinal quadrants did not begin until the counter quadrants had a total of seven septa, and counter acceleration continued throughout the neanic stage. The cardinal septum is long and in a poorly defined loculus formed by slight bowing of adjacent cardinal lateral septa. Minor septa were first noted about $8 \mathrm{~mm}$ above the tip (pl. 4, fig. 9), where they are difficult to distinguish from dissepimental traces; they attained a maximum length of $0.5 \mathrm{~mm}$ (about one-ninth the length of the major septa). The first tabular traces are evident $0.5 \mathrm{~mm}$ above the tip (pl. 4, fig. 3), but they did not become abundant until $8 \mathrm{~mm}$ above the tip (pl. 4, fig. 9). Dissepiments were first noted $3.5 \mathrm{~mm}$ above the tip (pl. 4, fig. 7), where they appear in transverse section as a single discontinuous ring of traces at the periphery of the corallum. By the end of the neanic stage (pl. 4, fig. $11)$, there were two to three rings of herringbone dissepiments. In the early neanic stage (pl. 4, figs. 3-5), the axial structure was manifested as a simple axial swelling of the union of pinnate major septa. At a level $2.5 \mathrm{~mm}$ above the tip (pl. 4, fig. 6), an axial plate oriented with its long dimension approximately in the cardinal-counter plane began to differentiate, and a few axial tabulae appeared. Gradual withdrawal of most of the major septa produced a more or less discrete axial structure made up of a slightly swollen axial plate augmented by tabellae and short, irregular septal lamellae by the end of the neanic stage (pl. 4, fig. 11). The axial

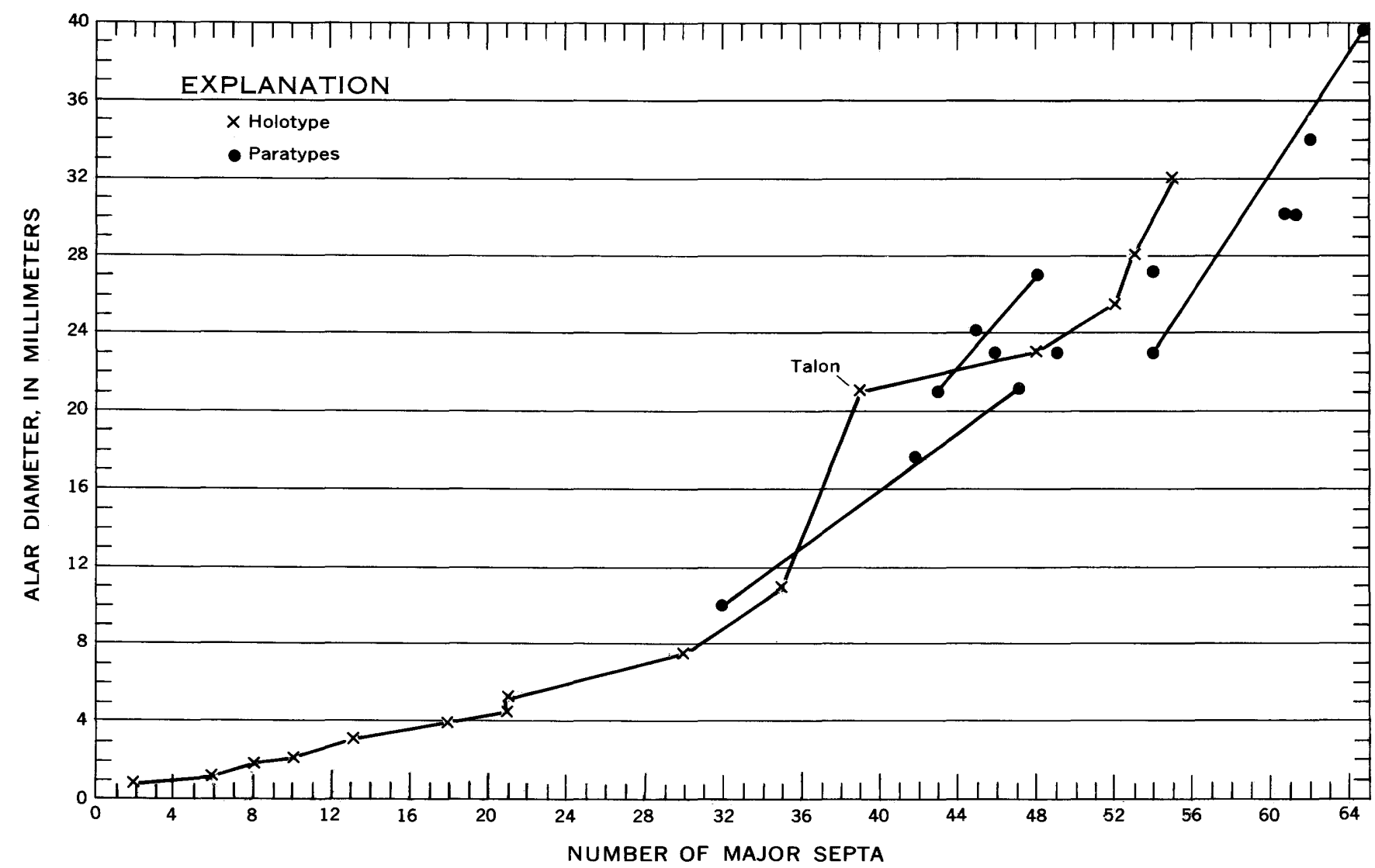

FIGURE 2.-Scatter diagram showing relation between alar diameter and number of major septa by means of 29 measurements on 12 specimens of Neokoninckophyllum hamatilis $\mathrm{n}$. sp. Straight lines connect measurements made from serial sections of holotype (USNM 165095) and three paratypes (USNM 165097, 165099, 165104). 
plate was connected to the cardinal and counter septa throughout the neanic stage.

The ephebic stage (table 6 , sections $1-0 ;$ pl. 4, figs. 12-15) comprises the upper $35 \mathrm{~mm}$ of the corallum, where increase in corallum length was greater than increase in corallum diameter (fig. 3). A total of 55 radially arranged major septa, whose length is about two-thirds the radius of the corallum, were developed by the end of this stage. Minor septa are consistently short (maximum length 1 $\mathrm{mm}$ ). Aside from increase in size and number of component elements, no major changes took place in the skeleton from the late neanic stage. The characteristic ephebic transverse section consists of a central axial structure, whose radius occupies about a third of the radius of the corallum, a periaxial tabularium, whose width occupies the middle third of the radius of the corallum, and a peripheral dissepimentarium, whose width occupies the outer third of the radius of the corallum. The axial structure consists of a thin axial plate oriented with its long axis in the cardinal-counter plane, loosely-arranged tabellae, and as many as six irregular septal lamellae. The axial plate was connected to both the cardinal and counter septa in the early ephebic stage (pl. 4, figs. 12, 13), but became free in the late ephebic stage (pl. 4, figs. 14, 15). The major septa are dilated in the tabularium. The dissepimentarium consists mostly of regular and herringbone dessepiments, but one lonsdaleoid dissepiment was noted in the highest section studied (pl. 4, fig. 15). There is a maximum of about nine rings of dissepimental traces.

The theca is very thin throughout growth; it never became thicker than about $0.3 \mathrm{~mm}$. Septal microstructure is the diffusotrabecular type of Kato (1963).

Description of paratypes.-The paratypes are all incomplete specimens that represent various parts of the conical or cylindrical stages of the species. Measurements of these specimens and the holotype suggests that the corallum was conical up to a

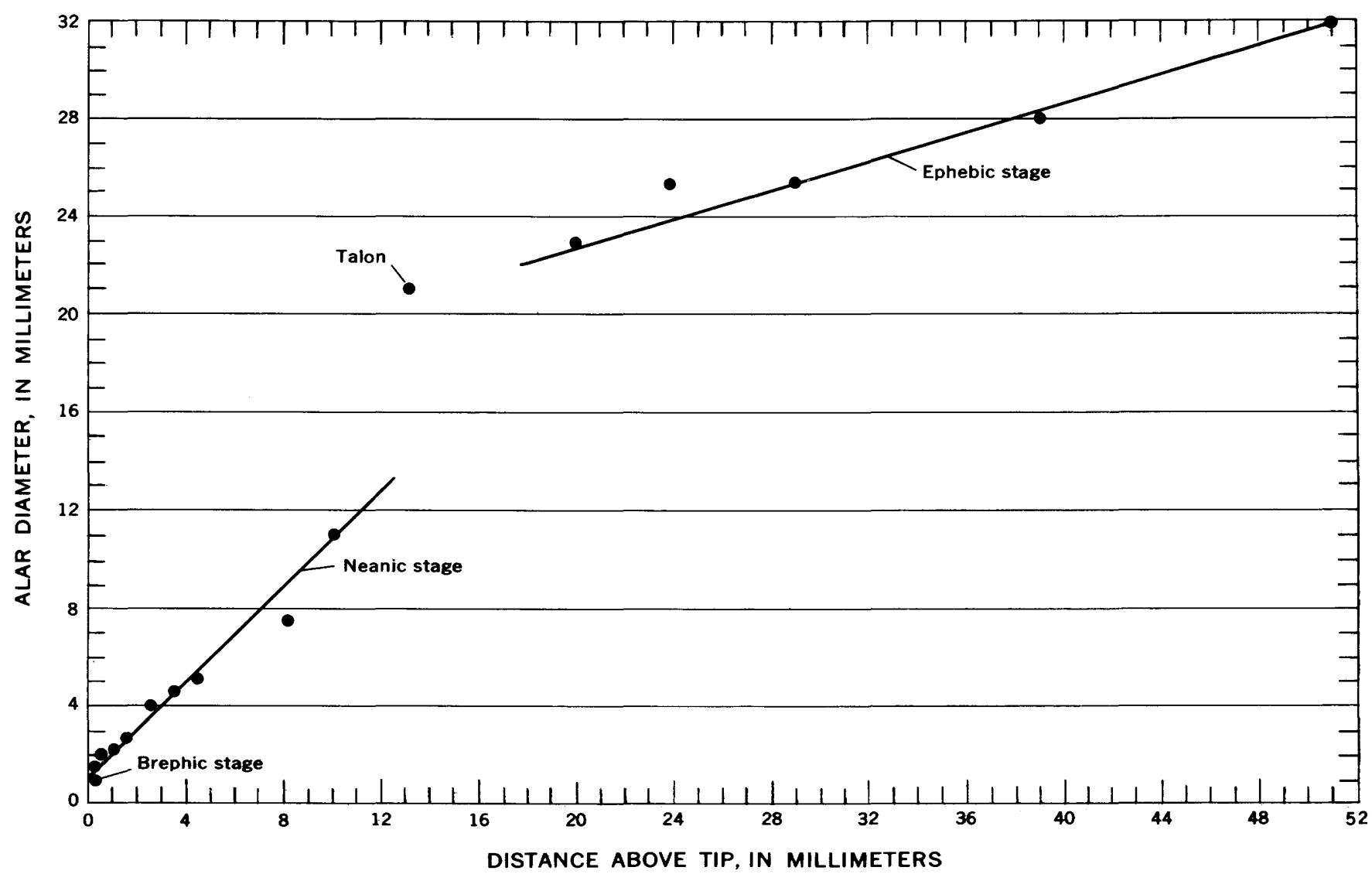

FIGURE 3.-Relation between alar diameter and distance above tip in the holotype of Neokoninckophyllum hamatilis n. sp. (USNM 165095). Straight lines fitted visually to points representing brephic, neanic, and ephebic stages in order to demonstrate changes in rate of diameter increase. 
TABLE 6.-Ontogeny in the holotype (USNM 165095) of Neokoninckophyllum hamatilis $n$. $s p$

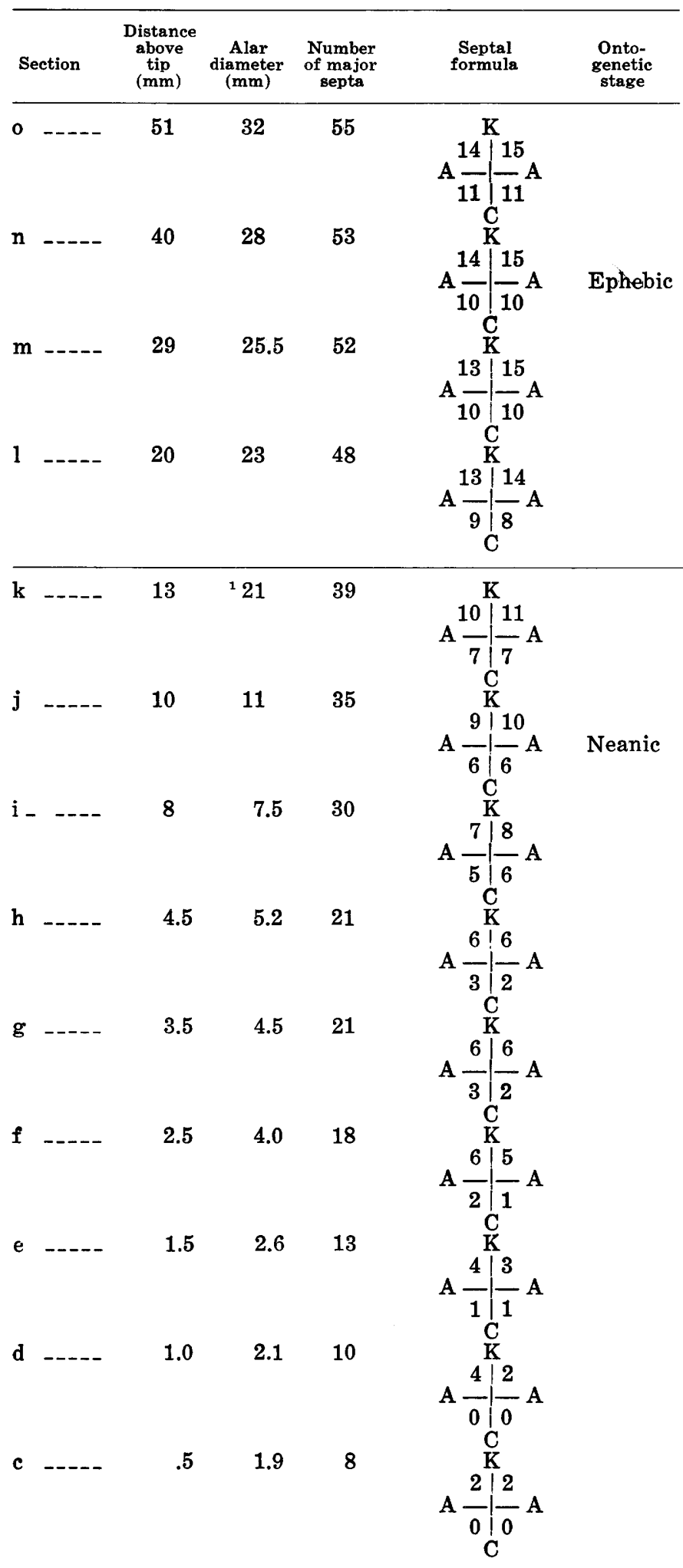

1 Includes talon.
TABLE 6.-Ontogeny in the holotype (USNM 165095) of Neokoninckophyllum hamatillis $n$. $s p$-Continued

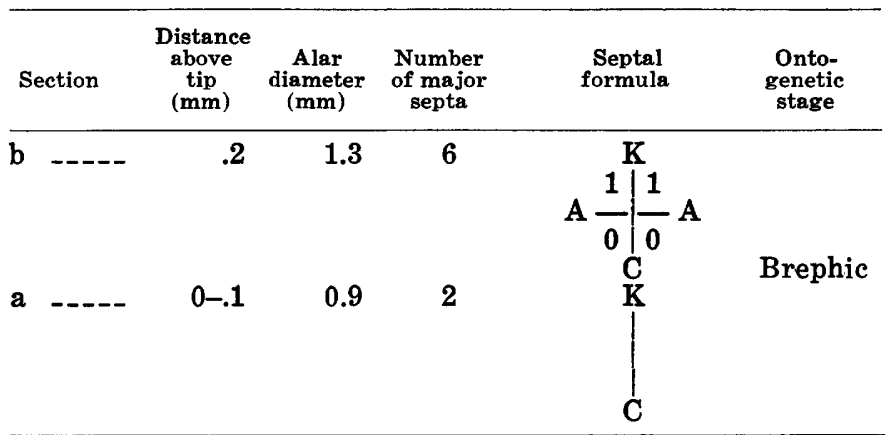

diameter of about 20 to $30 \mathrm{~mm}$, after which it became nearly cylindrical. Several fragmentary specimens (pl. 5, fig. 7) suggest that the cylindrical stage was sinuous and of considerable length. Maximum length attained was greater than $75 \mathrm{~mm}$. The maximum diameter observed in the paratypes is about $40 \mathrm{~mm}$, at which 65 major septa are present (fig. 2). All specimens in which the early part of the corallum is preserved exhibit evidence of supporting talons like that of the holotype (an example is shown on pl. 5, figs. 8, 9). Calices are rarely preserved except in some neanic specimens (pl. 5, fig. 10), where a moderately convex tabular floor is surmounted by low ridges formed by the axial plate and a few septal lamellae. The floor of the cardinal fossula is deeply depressed in these specimens.

Supplementary information on the internal morphology of the skeleton was obtained from nine transverse thin sections and six longitudinal thin sections cut from six paratypes. A typical late neanic stage is illustrated on plate 5, figures 1-3. The transverse sections (pl. 5, figs. 2, 3) of this specimen are similar in most respects to comparable sections of the holotype (pl. 4, figs. 10, 12). The longitudinal section (pl. 5, fig. 1), cut perpendicular to the cardinal-counter plane, exhibits the same three-fold zonation of the corallum seen in transverse section. The axial zone consists of a strong, straight, continuous axial plate surrounded by short tabellae that slope away from the plate at angles of about $45^{\circ}$ to $80^{\circ}$ from the horizontal. The periaxial tabellae rest on larger, more gently sloping, slightly convex or concave tabulae that blend into the tabulae of the tabularium. The tabularium consists of broad, nearly horizontal, inflated tabulae. The dissepimentarium is composed of 2 to 10 rows of inflated, steeply inclined, relatively small dissepiments.

Fragmentary cylindrical specimens (pl. 5, figs. 4-6, 11, 12) exhibit a somewhat different axial structure in late ephebic longitudinal sections. In these specimens, the axial plate is very thin, sinuous, 
and occasionally discontinuous. Steeply inclined periaxial tabellae are rarely developed, and the tabulae of the axial zone are broad, slightly convex, gently sloping plates that may or may not have downturned peripheral edges. In transverse section, the axial plate is difficult to identify, septal lamellae are rare, and tabular traces are haphazardly arranged. Tabulae of the tabularium are similar to those of the neanic stage. The dissepimentarium consists of as many as 13 rows of steeply inclined, mostly herringbone and regular dissepiments. Lonsdaleoid dissepiments are rare.

Discussion.-Although Neokoninckophyllum hamatilis shows some similarities to the species described by Moore and Jeffords (1945) from the Early Pennsylvanian of Texas and Oklahoma, it is clearly distinguishable by its larger corallum and details of its internal morphology. The mature stage of Neokoninckophyllum simplex Moore and Jeffords $(1945$, p. 159 , text figs. $149,150,156)$ is smaller, has fewer septa, and a narrower dissepimentarium made up of fewer rows of dissepiments than the Amsden species. Moreover, $N$. simplex lacks a septal stereozone and has a less well defined cardinal fossula.

$N$. arcuatum Moore and Jeffords (1945, p. 161, text figs. 157, 162-164) is also distinguished from $N$. hamatilis by its smaller size and fewer septa at maturity. $N$. arcuatum has longer minor septa, a less well defined cardinal fossula, a more regular axial structure, a more complex dissepimentarium, and its tabularium is not so well differentiated from the axial structure as in $N$. hamatilis.

N. gracile Moore and Jeffords $(1945$, p. 162, text figs. 158-161) is smaller, has fewer septa, and has a thinner dissepimentarium composed of fewer dissepiments than $N$. hamatilis. It is also distinguished from the Amsden species by its simpler axial structure.

N. sp. A. Moore and Jeffords (1945, p. 163, text figs. $165 \mathrm{a}-\mathrm{d}$ ) differs from $N$. hamatilis by its smaller corallum having fewer septa and its narrower dissepimentarium having fewer dissepiments. Moreover, its axial structure seems to lack an axial plate in the ephebic stage.

Occurrence and abundance.-Horseshoe Shale Member: collections $1(2+), 2(3), 3(26+), 4(20)$, 5 (4), Carbon County, Wyo.

Specimens.-Holotype, USNM 165095; paratypes, USNM 165096-108.

Neokoninckophyllum inconstans n. sp.

Plate 6

Diagnosis.-Solitary corals having a conical neanic stage and a cylindrical ephebic stage. Corallum as much as $60 \mathrm{~mm}$ or more in length and 27 $\mathrm{mm}$ in maximum diameter and having as many as 45 major septa at maturity. Exterior marked by subdued transverse and longitudinal ornament. Corallum supported by talons in early stages, Rejuvenation common. Theca thin. Septal plan pinnate in brephic and early neanic stages but radial in later stages. Cardinal septum long, located on convex side of corallum in conical stage, and in a very poorly defined fossula. Minor septa very short. Neanic axial structure consisting of a medial plate oriented in the cardinal-counter plane and continuous with cardinal and counter septa, periaxial tabellae and tabulae, and a few septal lamellae. Ephebic stage without axial structure or with discontinuous medial plate. Tabularium marked by a very weak septal stereozone and horizontal inflated tabulae. Dissepimentarium characterized by as many as eight rows of regular, herringbone, and lonsdaleoid dissepiments. Septal microstructure of the diffusotrabecular type of Kato (1963).

Description of holotype.-The holotype (USNM 165109 ; pl. 6, figs. 1-7) is an imperfect specimen in which neither the top nor the tip of the corralum are preserved. The corallum is a gently curved cone that expands from an alar diameter of about $5 \mathrm{~mm}$ to an alar diameter of about $18 \mathrm{~mm}$ in a preserved length of about $45 \mathrm{~mm}$. The lower $25 \mathrm{~mm}$ of the corallum is conical and has an apical angle (apex not preserved) of about $40^{\circ}$; the upper part of the corallum is approximately cylindrical. The cardinalcounter plane coincides approximately with the plane of curvature, and the cardinal septum is on the convex side of the corallum. The calice, although not completely preserved, was at least 10 $\mathrm{mm}$ deep. External details are lacking on most of the specimen owing to decortication, but the exterior seems to have been characterized by subdued longitudinal and transverse ornamentation.

The internal morphology of this specimen was studied by means of six transverse thin sections (pl. 6 , figs. 1-6) cut at intervals of 5 to $8 \mathrm{~mm}$ beginning about $3 \mathrm{~mm}$ above the base of the specimen. Alar diameter, number of major septa, septa formula, and ontogenetic stage for each of the sections are recorded in table 7 . The relation between number of major septa and alar diameter in various sections is compared with data from paratypes in figure 4.

The earliest section studied in this specimen represents the late neanic stage and is characterized by 26 major septa at an alar diameter of $7.3 \mathrm{~mm}$ 
(table 7, section a; pl. 6, fig. 1). The septal plan is radial, and the insertion positions are very poorly marked. Cardinal and counter septa are long and join the axial plate. The axial structure consists of an axial plate, a few tabellae, and the axial ends of three major septa. Most of the major septa are withdrawn from the axial region. The major septa are slightly dilated and wedge shaped within the tabularium, which is bounded by a weak stereozone. The dissepimentarium is thin (maximum width 1 $\mathrm{mm}$ ) and consists of two or three rows of herringbone or regular dissepiments. Short minor septa (maximum length $0.5 \mathrm{~mm}$ ) are present in the counter quadrants.

The neanic stage persists to an alar diameter of $17 \mathrm{~mm}$, where 34 major septa are developed (table 7, section d; pl. 6, fig. 4). The latest neanic sections are characterized by a radial septal plan, poorly defined insertion positions, and weak dilation in the tabularium (table 7, sections $c$ and $d ;$ pl. 6, figs. $3,4)$. A sinuous axial plate is still present and is connected to the cardinal and counter septa, but the axial tabellae are reduced in number and less regular, and only one or two short septal lamellae represent connections to the other major septa. The dissepimentarium is as much as $3 \mathrm{~mm}$ wide and consists of three or four rows of herringbone and regular dissepiments of unequal size. The tabularium is broad and exhibits few tabular traces. Minor septa remain short.

The ephebic stage (table 7 , sections e and $f$; pl. 6 , figs. 5,6 ) is characterized by the nearly cylindrical form of the corallum. At this stage, increase in corallum length was greater than increase in corallum diameter. In the holotype, the ephebic stage began when the corallum was approximately $18 \mathrm{~mm}$ in diameter and contained 36 major septa; the maximum number of major septa is 39 at the same diameter. The ephebic sections are distinguished from late neanic sectons by changes in the axial structure and dissepimentarium. The axial structure is reduced to a short, sinuous medial plate unconnected to the cardinal or counter septa and augmented by few or no accessory tabellae or septal

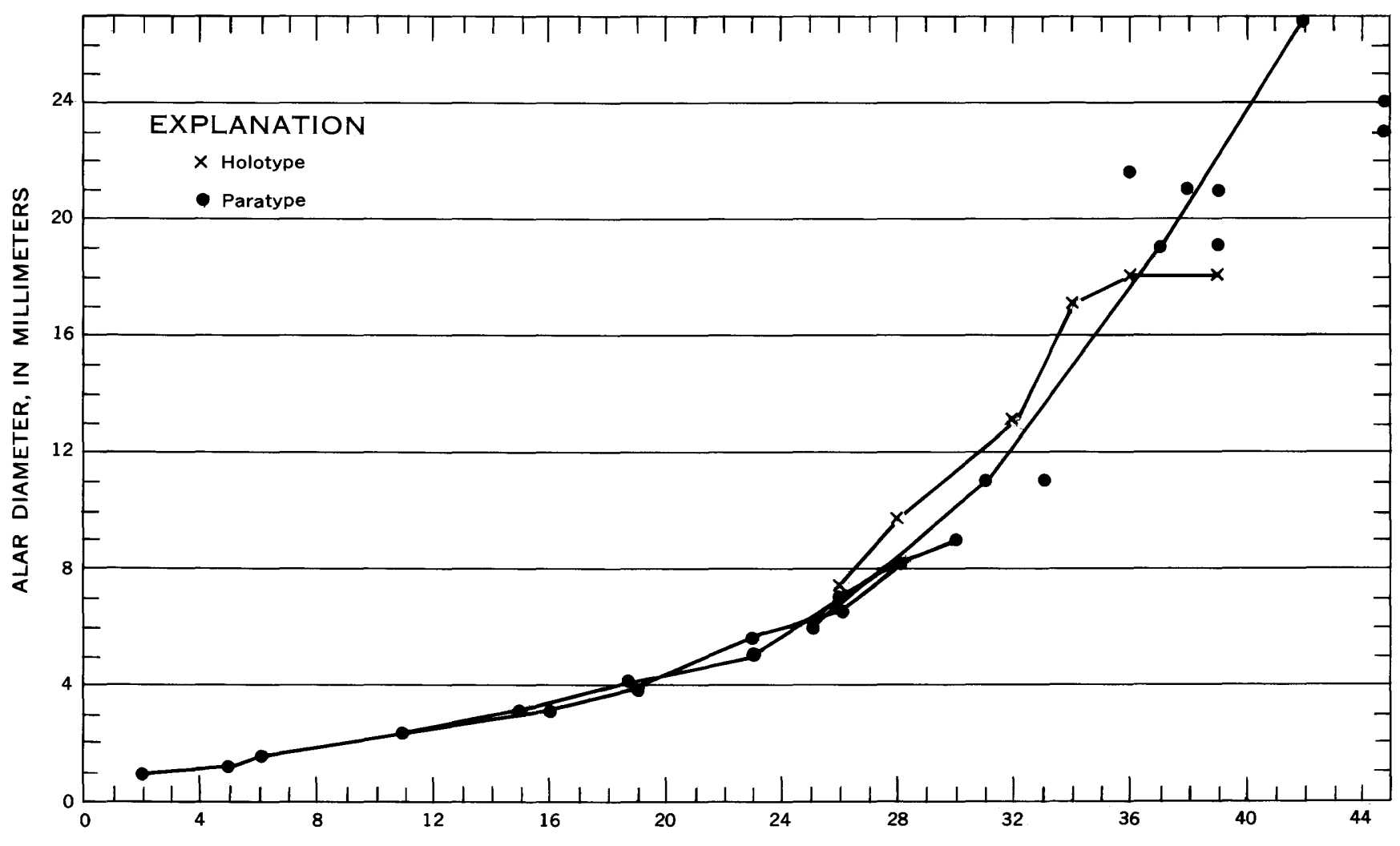

NUMBER OF MAJOR SEPTA

Figure 4.-Scatter diagram showing relation between alar diameter and number of major septa by means of 32 measurements on 11 specimens of Neokoninckophyllum inconstans n. sp. Straight lines connect measurements made from serial sections of holotype (USNM 165109) and three paratypes (USNM 165111, 165114, 165115). 
lamellae. In the dissepimentarium, lonsdaleoid dissepiments appear for the first time in addition to herringbone and regular dissepiments. The dissepimentarium is 3 or $4 \mathrm{~mm}$ wide, and the radius of the tabularium, including the weak axial structure, is 5 or $6 \mathrm{~mm}$. The theca is very thin $(0.1 \mathrm{~mm})$ and the minor septa are very short as in the neanic stage. Septal microstructure is of the diffusotrabecular type of Kato (1963).

Description of paratypes.-The paratypes are all incomplete specimens that represent various parts of the conical or cylindrical stage of the species. Most of the specimens are partly or completely decorticated. The conical stage is mostly slightly curved, rarely straight, and no more than 20 to 25 $\mathrm{mm}$ in length. Apical angles range from about $40^{\circ}$ to $70^{\circ}$; there are few specimens with a widely flaring corallum (pl. 6, fig. 29). Attachment scars or talons were observed on most specimens that have undecorticated tips preserved (pl. 6, fig. 28). The corallum is subcylindrical beyond a length of 20 to $25 \mathrm{~mm}$ and attained a maximum length of at least $60 \mathrm{~mm}$. The maximum diameter observed in the paratypes is about $27 \mathrm{~mm}$, at which diameter 42 major septa are present (fig. 4). Rejuvenation is common. The cardinal septum is on the convex side of the corallum in specimens with regular curvature in the conical stage. Neanic calices exhibit a moderately convex tabular floor surmounted by a median boss formed by the axial plate and septal lamellae (pl. 6, fig. 28).

Supplementary information on the internal morphology of the skeleton was obtained from 24 transverse thin sections, four transverse peels, and two longitudinal thin sections cut from 11 paratypes. Serial transverse sections of a paratype (USNM 165114, table 8; pl. 6, figs. 8-16) illustrate the brephic and neanic stages of the species. The earliest section studied (pl. 6, fig. 8), cut about 0.5 $\mathrm{mm}$ above the tip, revealed a single cardinal-counter septum. In the next two sections (pl. 6, figs. 9, 10), cut about 1.4 and $1.5 \mathrm{~mm}$ above the tip, respectively, the alar septa were observed, followed by addition of metasepta in the right counter quadrant. Strangely, two counter lateral septa appeared in the right counter quadrant before the appearance of any metasepta in the left counter quadrant. The earliest neanic section studied (pl. 6, fig. 11), cut about $2.5 \mathrm{~mm}$ above the tip, showed a complement of 16 major septa and a continuation of acceleration in the counter quadrants. In these brephic and early neanic sections, the septal plan was dominated by the coalesced cardinal and counter septa, but no
TABLE 7.-Ontogeny in the holotype (USNM 165109) of Neokoninckophyllum inconstans $n$. sp. Tip of specimen not preserved

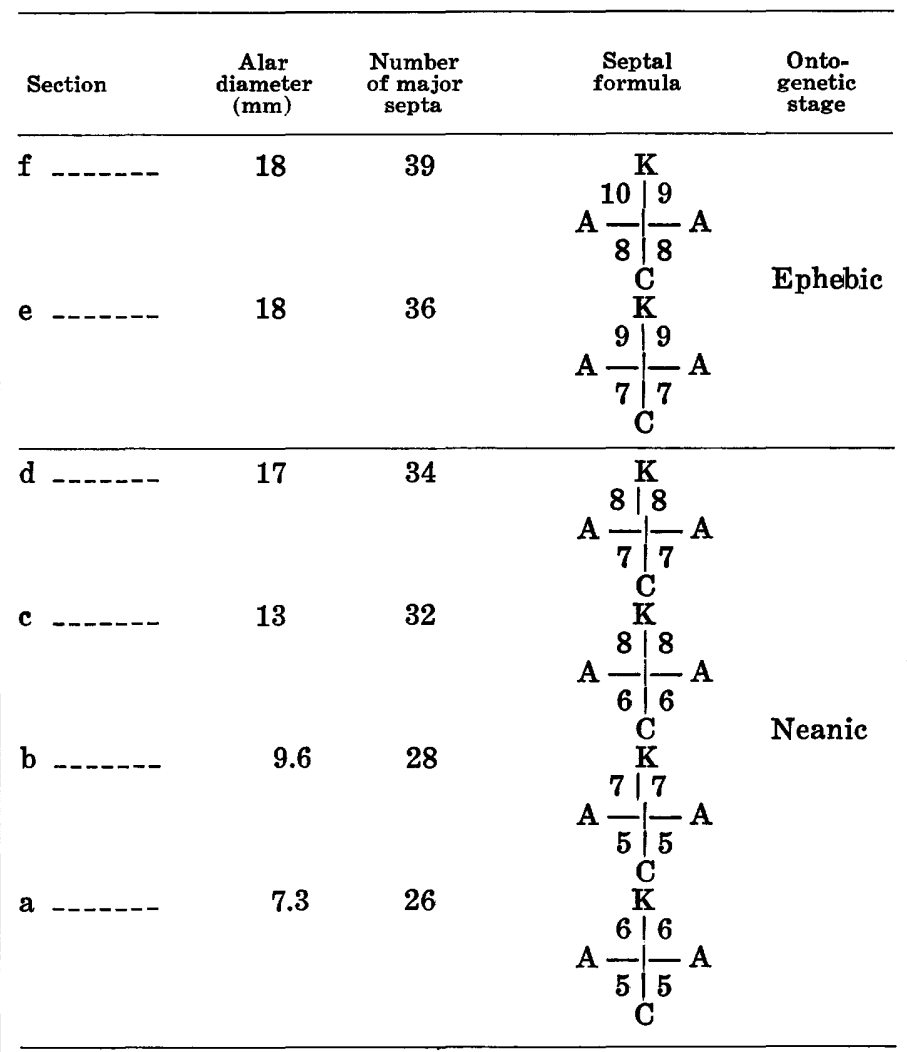

axial structure was evident. In the next neanic section (pl. 6, fig. 12), the septal plan was decidedly radial, and a few tabellae were concentric about the axially joined cardinal-counter plate to form a primitive axial structure. Succeeding neanic sections (pl. 6, figs. 13-16) were characterized by increased independence of a weak axial structure composed of an axial plate, axial tabellae, and septal lamellae and a radial septal plan composed of withdrawn major septa. A few short minor septa appeared in the last three sections of the series (pl. 6, figs. 14-16). Tabulae were noted in the earliest sections studied, but they did not become abundant until later in the series (pl. 6, fig. 12). Slight dilation of the major septa occurred in the tabularium. The dissepimentarium consisted of a few rows of herringbone and regular dissepiments.

Serial transverse sections of another paratype (USNM 165115; table 9; pl. 6, figs. 18-24) show features of the neanic stage of the species similar to those described above.

Typical ephebic transverse sections (pl. 6, figs. 25, $27,31,32$ ) show the absence of a discrete axial structure at this stage in the development of the 
TABLE 8.-Ontogeny in a paratype (USNM 165114) of Neokoninckophyllum inconstans $n$. $s p$.

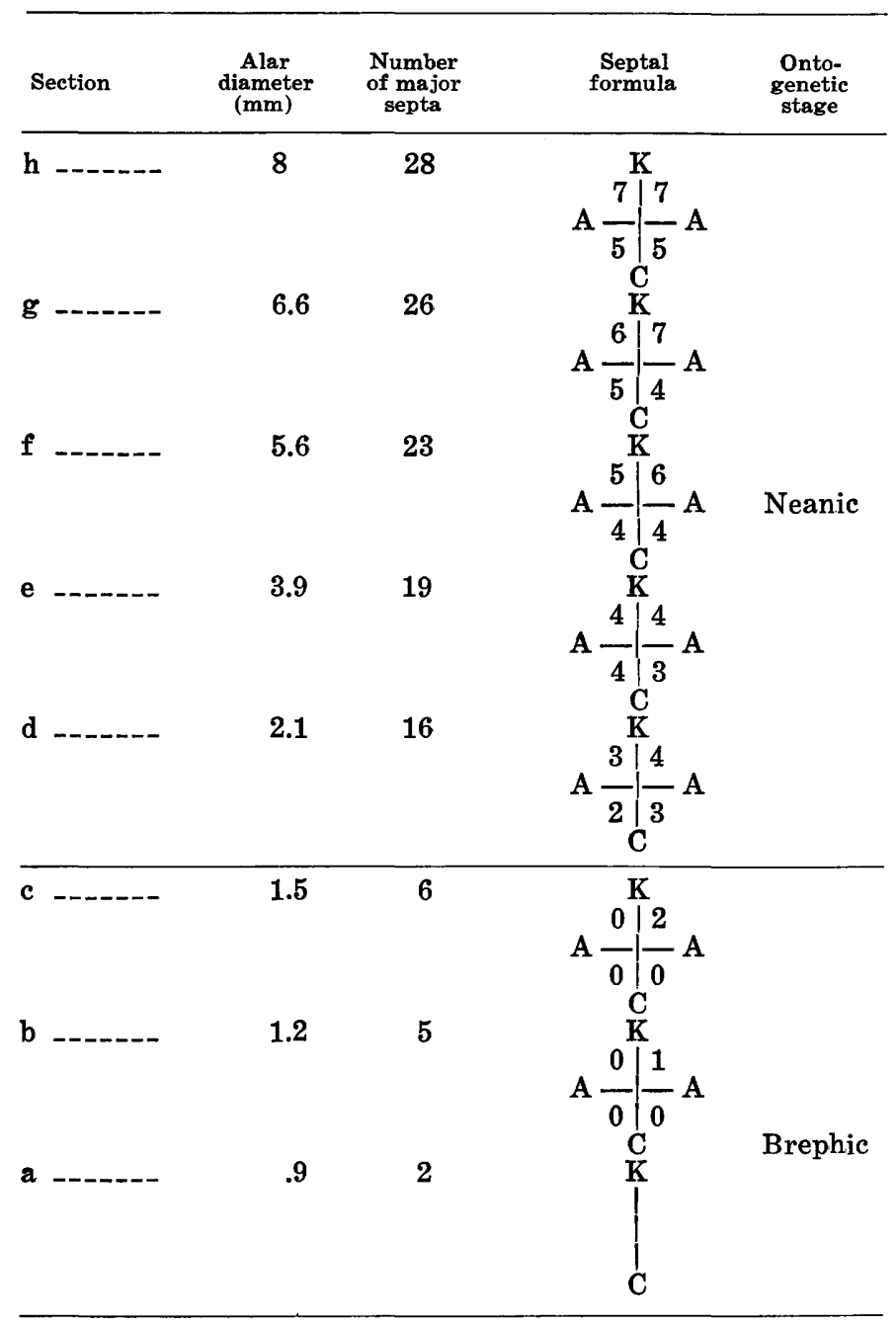

skeleton. Ordinarily all the major septa are withdrawn from the axial region, but in some sections several septa may extend haphazardly to a position near the axis (pl. 6, fig. 25). The septal plan is radial and insertion positions are so poorly marked that they cannot be identified in most specimens. The appearance of numerous lonsdaleoid dissepiments is a noteworthy feature of the ephebic stage. Dilation of septa in the tabularium is absent or very slight.

Longitudinal sections of the neanic and ephebic stages (pl. 6, figs. 26, 33) illustrate the weak and variable development of the axial structure in the ephebic stage. These sections also show a weak differentiation of the tabulae into axial and periaxial zones. The axial tabulae are broadly convex upward and tented only where an axial plate is present. The periaxial tabulae are convex, flat, or concave. The dissepimentarium consists of as many as eight rows of gently to steeply inclined inflated dissepiments of greatly unequal size.

Discussion.-Neokoninckophyllum inconstans is distinguished from $N$. hamatilis, the other Amsden species, by its smaller corallum and smaller number of major septa at maturity. Internal features that serve to differentiate it from $N$. hamatilis are the abundance of lonsdaleoid dissepiments and the absence of a continuous axial structure at maturity. $N$. inconstans is also characterized by less dilation of the major septa in the tabularium of the neanic and ephebic stages than $N$. hamatilis.

$N$. inconstans is distinguished from the species described by Moore and Jeffords (1945) from the Early Pennsylvanian of Texas and Oklahoma by its discontinuous and poorly developed axial structure in the ephebic stage and the presence of numerous lonsdaleoid dissepiments. It has a generally larger corallum than $N$. simplex Moore and Jeffords and $N$. gracile Moore and Jeffords. It also has a broader dissepimentarium and less well defined tabularium than $N$. gracile Moore and Jeffords.

Occurrence and abundance.-Horseshoe Shale Member: collection 7 (256), Carbon County, Wyo.

Specimens.-Holotype, USNM 165109 ; paratypes, USNM 165110-122.

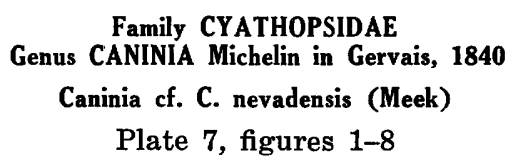

Description.-Corals included here are characterized by their large, solitary corallum that is trochoid in the early stages and expands rapidly to a cylindrical form at maturity. Fragmentary, commonly decorticated specimens suggest that this species commonly attained a length greater than $12 \mathrm{~cm}$; its diameter in the cylindrical stage was ordinarily between 5 and $6 \mathrm{~cm}$, although one specimen has a maximum diameter of $8 \mathrm{~cm}$.

Major septa ordinarily number between 50 and 60 at maturity, but there are 68 major septa in the largest specimen. The septa extend about two-thirds to three-fourths of the distance from the periphery of the corallum to the corallum axis at maturity. The cardinal septum is shorter than other major septa. Dilation in the cardinal quadrants is present in the immature stages of the corallum and may also be present in mature stages. In most transverse sections of the cylindrical stage, the major septa are not continuous through the dissepimentarium. Minor septa are very short and confined 
TABLE 9.-Ontogeny in a paratype (USNM 165115) of Neokoninckophyllum inconstans $n$. sp. Tip of specimen not preserved

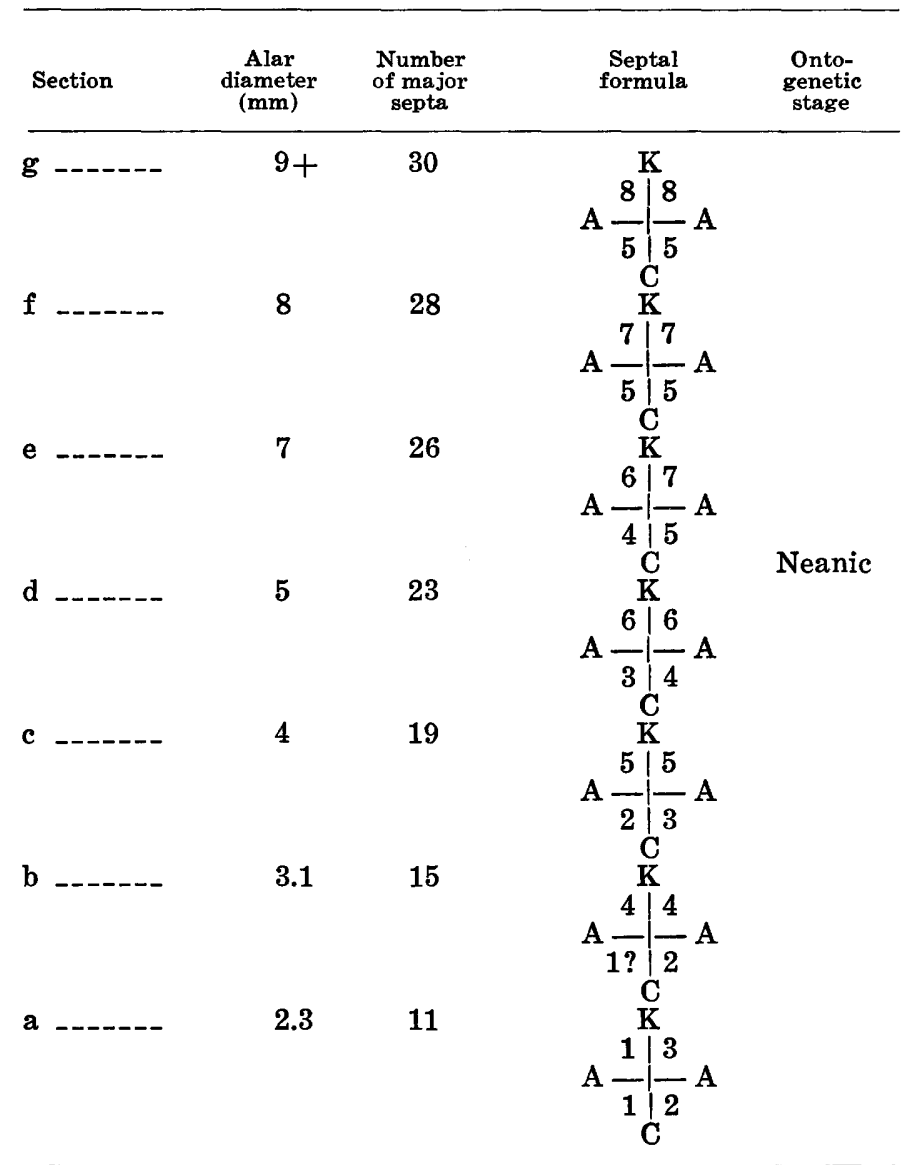

to a zone 1 to $4 \mathrm{~mm}$ wide at the periphery of the corallum.

The tabularium occupies about one-third of the diameter of the corallum in mature stages. Tabulae are variable in size and shape but are generally flat with downturned margins. They are spaced 0.5 to $2 \mathrm{~mm}$ apart; one specimen has about 15 tabulae in $1 \mathrm{~cm}$. No axial structure was observed in mature stages, but in some trochoid coralla an impersistent axial plate is formed by elongation of the counter septum (pl. 7, fig. 5).

The mature dissepimentarium characteristically consists of an outer zone of regular and herringbone dissepiments, a medial zone of lonsdaleoid dissepiments, and an inner zone of regular and herringbone dissepiments. The lonsdaleoid zone seems to be vertically and horizontally impersistent in some specimens. There may be as many as 10 to 12 rows of dissepiments at maturity. Dissepiments are variable in size and shape, globose to elongate, and generally steeply inclined.

Discussion.-There are no complete specimens in the material assigned to this species. The fragmentary nature of the specimens makes characterization of the species and appraisal of individual variation difficult. Sando (1965, p. E26-E27) has pointed out the difficulties in using the name Caninia nevadensis and the similarities between this species and Caninia excentrica (Meek) and Caninia enormis Easton. Present data on coral faunas of Chesterian age in the Western United States indicate that these faunas are characterized by large Caninias having curved conical or cylindrical coralla and a dissepimentarium that consists of a lonsdaleoid zone between regular and herringbone zones. Collections studied thus far do not indicate whether the conical forms represent a species distinct from the cylindrical forms. Until such time as better material is found, it seems desirable to recognize the two growth forms as separate species.

A fourth species that is allied to this group of Chesterian Caninias is Caninia montanensis Easton (1962, p. 33, pl. 3, figs. 18-20) from the Heath Formation of central Montana. This is a diminutive conical form that seems to have been derived from the Caninia excentrica-Caninia nevadensis stock when the Chesterian sea swept into the Big Snowy basin from the miogeosynclinal trough in Idaho.

Occurrence and abundance.-Moffat Trail Limestone Member: collections 73(1), 74(18), 76(1), $77(6), 78(3), 79(4), 88(2), 91(5), 92(2), 93(2)$, $104(2), 105(12), 109(9)$, Lincoln County; $124(2)$, $126(6)$, Teton County, Wyo.

Specimens.-USNM 165123-141.

\section{Genus TURBINATOCANINIA Dobrolyubova, 1970 Turbinatocaninia? sp. \\ Plate 7, figures 9-19}

Description.-This category includes fragmentary specimens of small, subcylindrical to vermiform corals. Although most of the specimens appear to have a solitary habit, one specimen (pl. 7, fig. 19) showed evidence of budding. The coralla range from about $4 \mathrm{~mm}$ to about $20 \mathrm{~mm}$ in diameter. The longest specimens observed are about $50 \mathrm{~mm}$ in length.

Major septa range in number from 20 in a corallum $6 \mathrm{~mm}$ in diameter to 37 in a corallum $18 \mathrm{~mm}$ in diameter. The major septa ordinarily extend about half the distance from the epitheca to the axis of the corallum; they are commonly dilated in the cardinal quadrants. The cardinal septum is ordinarily shorter or thinner than the other major septa, but the cardinal fossula is poorly defined. Minor septa are commonly absent in the younger stages of the corallum and never attain a length 
greater than about a third of the length of the major septa.

The axial zones of some coralla are characterized by an impersistent, sinuous axial plate formed by elongation of the counter septum (pl. 7, figs. 11-13, $15,16)$; one to three accessory lamellae that may or may not join other major septa are commonly present. About half the transverse sections examined show a weak and variable axial structure, which seems to be most characteristic of coralla having fewer than 30 major septa.

The tabularium comprises all but 1 to $4 \mathrm{~mm}$ of the diameter of the corallum and ordinarily consists of flat tabulae with downturned edges (pl. 7, figs. 9, 10, 19). Where a columella is present, the tabulae may be slightly tented upward (pl. 7, fig. 15). Tabulae are spaced 0.5 to $1.5 \mathrm{~mm}$. The dissepimentarium consists ordinarily of one to four rows of regular or herringbone dissepiments. However, dissepiments are absent in parts of some young coralla, and a few lonsdaleoid dissepiments are present in some specimens.

Discussion.-The material at hand poses difficult taxonomic problems owing to its fragmentary nature and its morphologic variability. Some of the smaller cylindrical fragments were originally interpreted as disaggregated corallites of the lithostrotionid genus Nemistium. This interpretation was abandoned when coralla of comparable diameter and morphology were found to be parts of larger, distinctly solitary specimens having a weak cardinal septum and dilated major septa in the cardinal quadrants.

The general morphology of this species is suggestive of the genus Caninia as this term is generally used in a broad sense. Characteristic features are the broad tabularium, peripheral dissepimentarium, major septa that ordinarily do not reach the axis of the corallum, weak cardinal septum, dilation of major septa in the cardinal quadrants, and principally solitary habit. On the other hand, the presence of an impersistent columella in some parts of the corallum is inconsistent with the commonly accepted definition of Caninia. Dobrolyubova (1970) described a similar inconsistency of morphology in some corals from the Viséan of the U.S.S.R., for which she proposed the genus Turbinatocaninia. According to Dobrolyubova (1948), these corals form a part of a phylogenetic series from Dibunophyllum through Koninckophyllum to Caninia.

Occurrence and abundance.-Moffat Trail Limestone Member: collections 73(7), 75(1)), 76(2), $77(2), 78(3), 79(10), 88(10), 91(4), 92(1), 93(1)$,
$103(7), 105(63), 109(7)$, Lincoln County ; $124(4)$, Teton County, Wyo.

Specimens.-USNM 165144-166.

\section{Suborder COLUMNARIINA \\ Family LONSDALEIIDAE \\ Subfamily LONSDALEIINAE \\ Genus LONSDALEIA McCoy, 1849}

Subgenus ACTINOCYATHUS d'Orbigny, 1849

1849. Actinocyathus d'Orbigny, p. 12.

1861. Stylidophyllum de Fromentel, p. 316.

Type species.-Cyathophyllum crenulare Phillips, 1836 equals Erismatolithus Madreporites (floriformis) Martin, 1809 equals Lonsdaleia floriformis (Martin).

Diagnosis.—Cerioid Lonsdaleia.

Discussion.-Most students of Paleozoic corals have included both fasciculate and massive species in the genus Lonsdaleia. However, as early as 1861, de Fromentel proposed the genus Stylidophyllum to distinguish massive corals with the internal structure of Lonsdaleia, whose type species is a fasciculate form. In recent years, beginning with Chi (1931), many authors have used de Fromentel's concept in describing corals of Carboniferous and Permian age in China, Japan, Iran, the Carnic Alps, and the U.S.S.R. The concept has been applied mostly commonly to Permian corals of the Tethyan region; most of these species have been reallocated most recently to Yoloyamaella Minato and Kato, Ipciphyllum Hudson, and Wentzelophyllum Hudson by Minato and Kato (1965).

Smith (1916, p. 257) studied a specimen that he considered to be the holotype of Cyathophyllum crenulare Phillips, the type species of Actinocyathus d'Orbigny, and concluded that it "is a characteristic specimen of Lonsdaleia floriformis," the most widely known cerioid species of Lonsdaleia. Kato (1966, p. 102) studied the same specimen, which he designated as lectotype of Phillips' species, and also concluded that it is conspecific with Lonsdaleia floriformis (Martin). Inasmuch as Stylidophyllum de Fromentel, 1861, is based on the same species (by subsequent designation of Chi, 1931, p. 44), Stylidophyllum is a junior synonym of Actinocyathus.

Kato (1966, p. 100-101) discussed the question of the validity of growth form as a generic character in the group of corals ordinarily referred to Lonsdaleia and concluded that the name Actinocyathus should be applied to the cerioid forms while retaining Lonsdaleia for the fasciculate forms. Although this question is controversial, I agree with Kato that growth form is a useful taxonomic distinction in this group of corals. However, until there is further 
clarification of the phylogenetic significance of growth form, I propose to give this character only subgeneric rank. Accordingly, I divide the genus Lonsdaleia McCoy into subgenus Lonsdaleia McCoy (fasciculate forms) and subgenus Actinocyathus d'Orbigny (cerioid forms).

Although both subgenera of Lonsdaleia have been reported in beds ranging from Early Carboniferous to Permian in age, recent taxonomic revisions of Middle Carboniferous and Permian corals have resulted in reallocation of most of the post-Early Carboniferous species formerly assigned to this genus. It seems probable that further revisions will result in restriction of Lonsdaleia to the Lower Carboniferous.

\section{Lonsdaleia (Actinocyathus) stelcki (Nelson) Plate 8}

1960. Lithostrotionella stelcki Nelson, p. 119-120, pl. 23, figs. 6-10.

1963. Lithostrotionella cf. L. stelcki Nelson. Sando in Dutro and Sando, p. 1982.

1969. Lithostrotionella cf. L. stelcki Nelson. Sando in Sando, Mamet, and Dutro, p. E11.

Diagnosis.-Actinocyathus having corallites that average between 5 and $13 \mathrm{~mm}$ in diameter and contain an average of between 14 and 26 major septa. Minor septa absent to well developed. Axial structure weakly arachnoid, composed of an axial plate that originates as an extension of one or two major septa, a variable number of septal lamellae, and axial tabellae; entire complex commonly strongly reinforced by stereoplasm, forming a solid axial rod that is oval to circular in transverse section and 1 to $2 \mathrm{~mm}$ in diameter. Tabulae flat to concave upward. Axial tabellae nearly vertical to vertical. Dissepiments variable in size, lonsdaleoid, in one to three poorly defined rows. Corallite walls strongly corrugated.

Description.-The Amsden specimens are all fragments of colonies; the largest corallum observed in the field was about 8 inches high and 2 feet in diameter. Budding was peripheral. Corallite walls are strongly corrugated.

Corallites range from 3.2 to $10.5 \mathrm{~mm}$ in diameter; average corallite diameter per corallum ranges from 5.6 to $7.5 \mathrm{~mm}$. Major septa range in number from 10 to 24 ; average septal number per corallite per corallum ranges from 14.5 to 19.8 .

Major septa are ordinarily confined to the tabularium, except for one or two (presumably counter and cardinal) that commonly join the axial plate. Extensions into the dissepimentarium as septal crests are rare. Minor septa are generally rare or absent; where present they are one-fourth to onehalf the length of the major septa.

The axial structure is composed of an axial plate that is continuous with 1 or 2 major septa, 1 to 10 septal lamellae, and nearly vertical axial tabellae. Stereoplasmic thickening of the axial complex is variable within the colony; most coralla have at least a few corallites with solid axial rods, but many corallites show little or no thickening. The axial structure is oval to circular in transverse section and 1 to $1.5 \mathrm{~mm}$ in diameter.

The tabularium ranges from 1.8 to $5.4 \mathrm{~mm}$ in diameter and has an average diameter per corallum of 3.3 to $4.1 \mathrm{~mm}$. Tabulae are mostly concave upward but some are horizontal and a few show slight upward convexity. The tabulae terminate sharply at their junctions with the dissepimentarium and the axial complex. There are about three to five tabulae in $1 \mathrm{~mm}$ vertically.

The dissepimentarium consists of one to three variable and poorly defined rows of lonsdaleoid dissepiments. The dissepiments are variable in size, moderately to strongly inflated, and inclined from the corallite walls at an angle of about $30^{\circ}$ to $45^{\circ}$ from the horizontal.

Discussion.-Cerioid rugose corals are relatively rare in rocks of Chesterian age in western North America; the only corals of this description have been referred to Lithostrotionella stelcki Nelson. Previous allocation of this species to Lithostrotionella Yabe and Hayasaka was due to the weakly arachnoid nature of the columella and the pronounced stereoplasmic thickening of the columella in many corallites. Careful study of many transverse thin sections shows that all elements of the complex columella characteristic of Lonsdaleia are present in contrast to the simpler columella of Lithostrotionella, which lacks persistent axial tabellae and discrete septal lamellae.

In order to determine the degree and nature of morphological variation in this species, I studied 10 colonies of the species from the Western United States and 4 colonies from western Canada (through the courtesy of E. W. Bamber of the Geological Survey of Canada). These were compared with Nelson's holotype and paratype, obtained through the courtesy of C. R. Stelck of the University of Alberta. Data from this study are shown in table 10 and figure 5 .

Conclusions drawn from the study are as follows:

1. All the specimens studied have the distinctive tabulation and complex axial structure that 
characterize the type specimens of Lonsdaleia (Actinocyathus) stelcki. The specimens are also characterized by their corrugated corallite walls and one to three rows of variable lonsdaleoid dissepiments.

2. Average corallite diameter per colony, average number of major septa per corallite per corallum, development of minor septa, and stereoplasmic thickening of the axial structure are variable features in the material studied.

3. A graph of average corallite diameter per colony plotted against average number of major septa per corallite per corallum (fig. 5) indicates that most of the colonies cannot be separated into more than one discrete taxonomic entity on these characters. Only one colony (GSC 49354) is sufficiently distinct to warrant consideration as a separate taxon. No geographic variants are discernible on the graph.
4. Variations in development of minor septa and thickening of the columella are similarly unsystematic and seemingly unrelated to corallite diameter and septal number (table 10).

5. These data support inclusion of all the material studied in one species with the possible exception of GSC 49354, which is distinguished by its much larger corallites and greater septal number per corallite. Inasmuch as GSC 49354 exhibits other characters that unite it with the majority of the specimens, it might be practical to recognize it as a distinct subspecies. However, formal recognition is deferred pending discovery of more and better specimens of this variant.

Occurrence and abundance.--Moffat Trail Limestone Member: collections 90(6), 92(2), 104(4), 105 (1), Lincoln County, Wyo.

Specimens._USNM 165167-173.

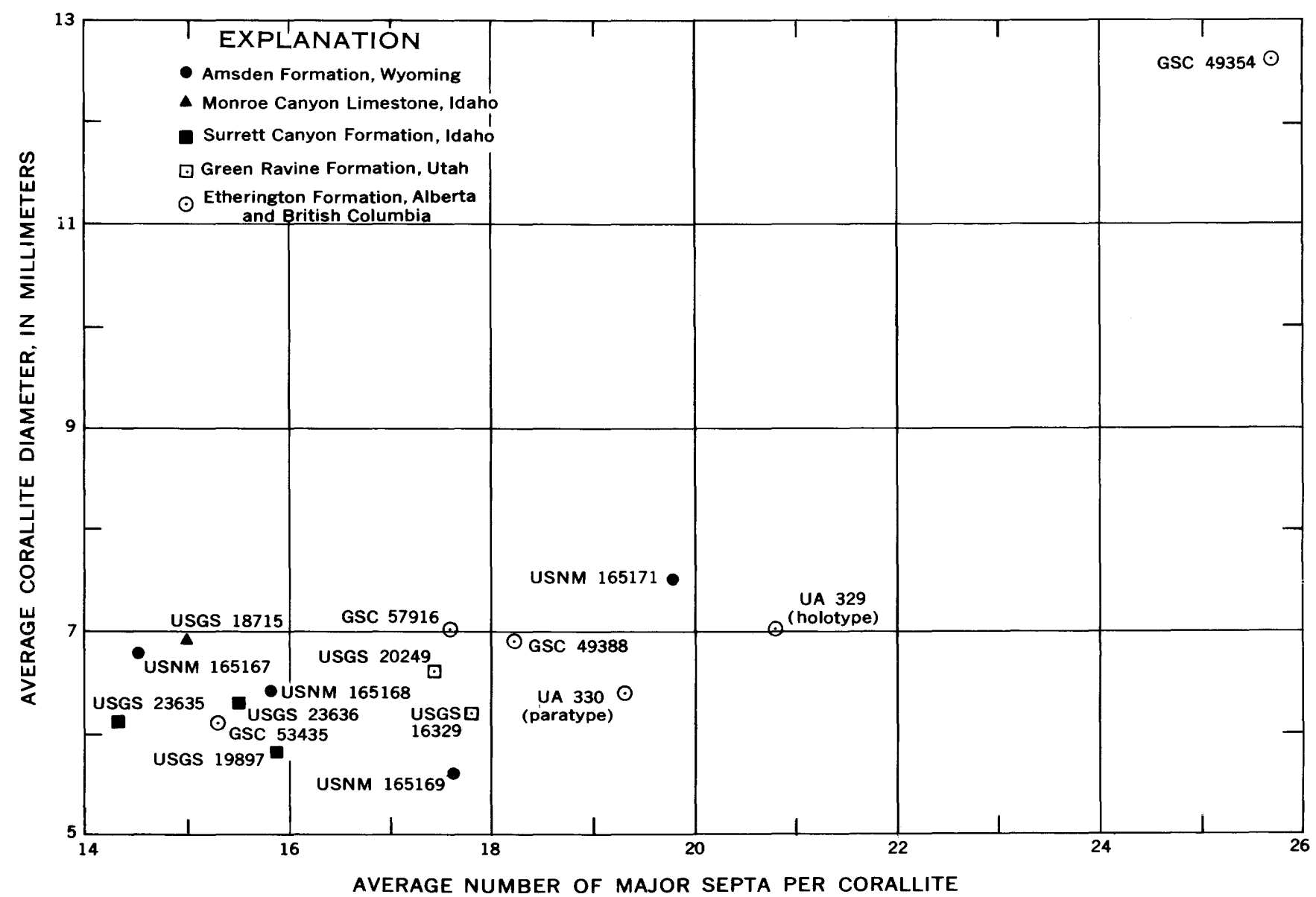

FIGURe 5.-Variation in average corallite diameter per colony and average number of major septa per corallite in colonies of Lonsdaleia (Actinocyathus) stelcki (Nelson) from beds of Chesterian age in western North America. Numbers refer to U.S. National Museum collections (USNM), U.S. Geological Survey collections (USGS), Canada Geological Survey collections (GSC), and University of Alberta collections (DA). 
TABLE 10.-Variation in colonies of Lonsdaleia (Actinocyathus) stelcki (Nelson) from the United States and Canada

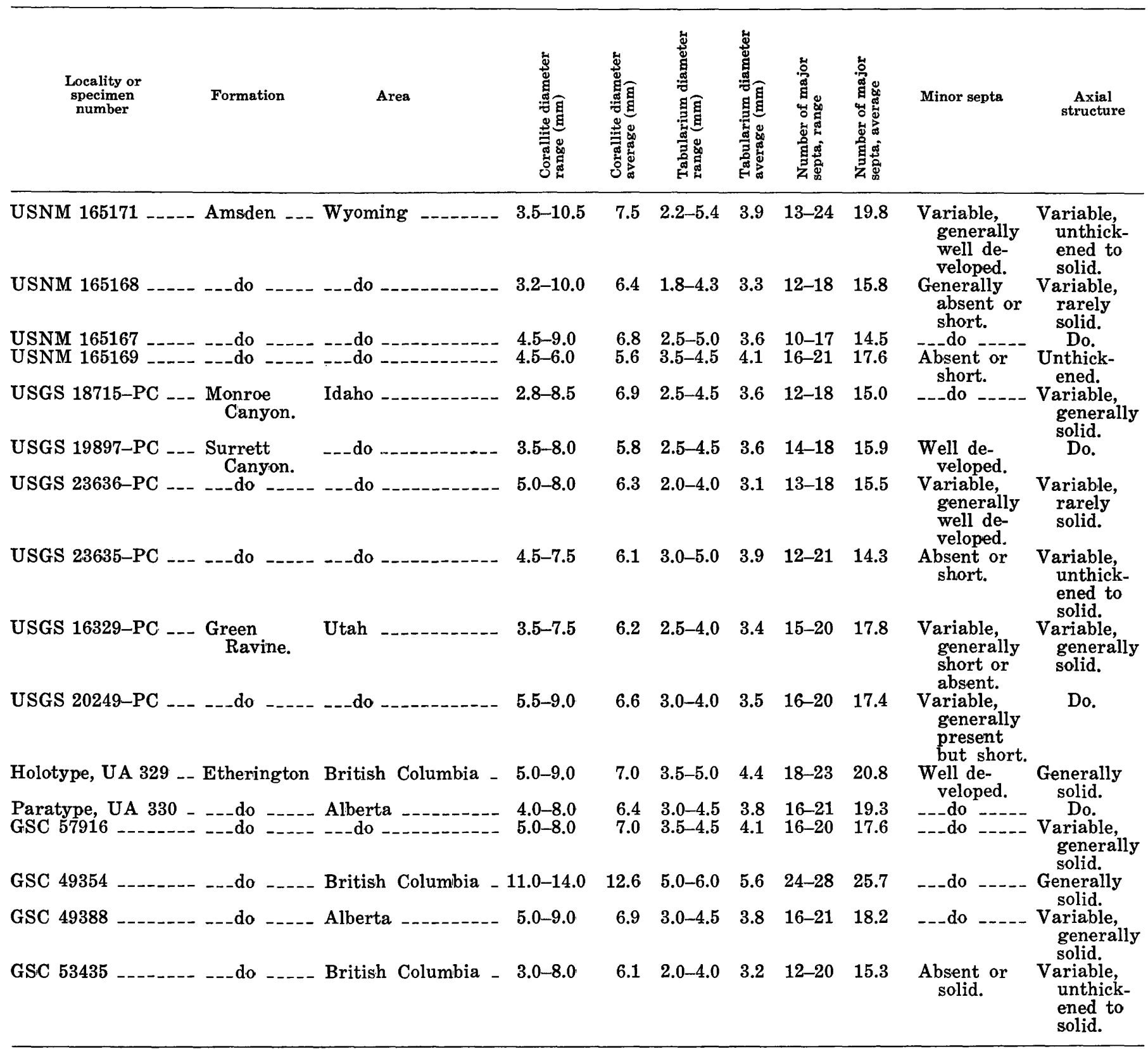

Order TABUlata

Family SYRINGOPORIDAE

Genus Pleurosiphonella Chudinova, 1970

Type species.-Pleurosiphonella crustosa Chudinova $(1970$, p. 105, pl. 38, figs. 1, 2).

Diagnosis.-Corallum fasciculate, phaceloid or dendroid, composed of relatively thick walled, cylindrical corallites that are joined at irregular intervals and connected by mural pores or very short connecting tubules. Corallites commonly joined to form short chains or clusters at some levels in the corallum. Increase lateral, commonly multiple. Tabulae mostly vesicular, ordinarily vertically disposed along one side of the corallite wall in such a way as to leave a visceral canal along the other side or tabulae may be infundibular, having the axis of the funnels closer to one side of the corallite than the other. Septal spines rare or absent in some species, present in others. Wall structure fibrous.

Discussion.-Nelson (1962, p. 444) distinguished a group of three syringoporid species in the Mississippian of western Canada that are characterized by eccentric visceral canals, relatively thick walls, and corallites joined by anastomosis. He included 
Syringopora virginica Butts, S. magnussoni Nelson, and $S$. drummondi Nelson in this group but did not propose a new generic name for it. Chudinova (1970) established the name Pleurosiphonella for similar forms from the Tournaisian of Armenia. Having noted such corals in the Amsden Formation of Wyoming, I examined the type specimens of the type species through the courtesy of Dr. Chudinova when I was in Moscow in 1971 and concluded that the American and Armenian forms are congeneric.

According to Chudinova (oral commun., 1971), the genus is known from the Tournaisian of Armenia and the Tournaisian and Visean of the Ural Mountains. Lonsdale (1845, p. 592-593) described a specimen from the Carboniferous Limestone at Ilinsk, U.S.S.R. under the name of Syringopora distans (Fischer von Waldheim) in which he noted eccentric visceral canals. Although this may belong in Pleurosiphonella, I have not been able to verify the identification. On the other hand, Pickett (1966, p. 36, pl. 20, figs. 3, 4) described and illustrated Syringopora pachytheca Pickett from the Halls Creek Limestone (middle Viséan, cu $\mathrm{II} \beta-\gamma$ ) in the New England District, New South Wales, which is characterized by an eccentric visceral tube and is here included in the genus. Pickett's species is distinguished from other species of Pleurosiphonella by its very thick deposits of stereoplasm between the visceral canal and the corallite wall.

According to Nelson (1962, p. 444), the Canadian species here referred to Pleurosiphonella are most common in the Meramecian and rare in the late Osagean. However, a revision of the position of the Osagean Meramecian boundary by Macqueen, Bamber, and Mamet (1972) indicates that the Canadian occurrences are exclusively post-Osagean, which is more in accord with the writer's knowledge of the range of the genus in the United States.

Pleurosiphonella virginica is the most common North American species. Nelson (1962, fig. 7) recorded it in the Livingstone (upper part), Mount Head, and Etherington (lower part) Formations of western Canada in beds of Meramecian and Chesterian age. The species was originally described from strata equivalent to the St. Louis Limestone in Virginia. In the Western United States, it occurs in the Monroe Canyon Limestone of southeast Idaho and the Scott Peak Formation of south-central Idaho. Its known range in the Western United States is in Zones E and F of Sando, Mamet, and Dutro (1969), an interval of middle and late Meramecian age (equivalent to V2b through V3b of the
Viséan of Europe).

Pleurosiphonella magnussoni ranges from the upper part of the Livingston Formation through the Mount Head Formation and into the lower part of the Etherington Formation (Nelson, 1962, fig. 7). The age range is middle Meramecian into the early Chesterian (equivalent to parts of the middle and upper Viséan of Europe). This species has not been identified in the United States.

Pleurosiphonella drummondi was recorded by Nelson (1962, fig. 7) exclusively in the upper part of the Etherington Formation of Chesterian age in western Canada. It is described below from the Amsden Formation of western Wyoming, where it occurs in Foraminiferal Zones 17 and 18, an interval of late Chesterian age (equivalent to $\mathrm{E}_{1}$ and $\mathrm{E}_{2}$ of the Namurian of Europe).

\section{Pleurosiphonella drummondi (Nelson) \\ Plate 9, figures 1-4}

1962. Syringopora drummondi Nelson, p. 458, pl. 72, figs. 12-14; pl. 75, figs. 8-11; text fig. 4 i.

Description.-Specimens from the Amsden are fragments of colonies; the largest corallum observed was at least $6 \mathrm{~cm}$ high and $16 \mathrm{~cm}$ in diameter. Corallites are subparallel and connected at irregular intervals of about $1 \mathrm{~cm}$ by short connecting tubules or by mural pores without connecting tubules.

In transverse sections, corallites have circular to oval cross sections and appear to be connected in short chains at some levels in the corallum. Corallite diameters range from 1.8 to $2.8 \mathrm{~mm}$; average corallite diameters in two measured coralla are $2.4 \mathrm{~mm}$ and $2.3 \mathrm{~mm}$, respectively (fig. 6). Corallites are spaced as much as $4 \mathrm{~mm}$ apart; the average corallite frequency in two measured coralla is 7.8 and 8.7 corallites per square centimeter (fig. 6). Wall thickness ranges from 0.1 to $0.5 \mathrm{~mm}$. The microstructure of the wall appears to be fibrous, with fibres radially arranged. Tabular traces are numerous and concentric, having the center of concentricity located closer to one side of the corallite. Septal spines are abundant in one specimen and seemingly absent in another, although poor preservation may be a factor in the latter. Where present, the spines are as much as $0.3 \mathrm{~mm}$ long and located on both the corallite wall and on tabulae.

Occurrence and abundance.-Moffat Trail Limestone Member: collections 78(1), $109(2)$, Lincoln County, Wyo.

Specimens.-USNM 165174-176. 


\author{
Family MULTITHECOPORIDAE \\ Genus MULTITHECOPORA Yoh, 1927 \\ Multithecopora? amsdenensis n. sp. \\ Plate 9, figures 5-9
}

Description.-The Amsden specimens are all fragments of coralla; the largest corallum was at least $5 \mathrm{~cm}$ high and $11 \mathrm{~cm}$ in diameter. The coralla are all phaceloid to subdendroid; most of the corallites are subparallel. Corallites are subcylindrical; their cross sections range from circular to rounded polygonal. The epitheca of individual corallites is marked by rugae, fine growth lines, and commonly shows abundant talons. Corallites are connected by short connecting tubules or by mural pores where the corallite walls are in close contact with one another. There are commonly one or two connecting tubules or mural pores at a given level in a corallite, although there may be as many as four. These connections between corallites occur commonly at intervals of about $4 \mathrm{~mm}$. Increase is commonly multiple; as many as three offsets may arise at one level in a corallite.

Corallites range from 1.5 to $2.7 \mathrm{~mm}$ in diameter; average corallite diameter measured in thin sections of five coralla ranges from 1.9 to $2.2 \mathrm{~mm}$ (fig. 6). Corallites are spaced as much as $5 \mathrm{~mm}$ apart, and average corallite frequency measured in five coralla ranges from 7.1 to 13.3 corallites per square centimeter (fig. 6). Wall thickness is extremely variable, ranging from 0.1 to $1.0 \mathrm{~mm}$ in five coralla. Concentric layers of stereoplasm are common in thickened walls of some corallites, but the visceral cavity ordinarily occupies at least one half to two-thirds the diameter of the corallite.

Tabulae are relatively sparse and erratically distributed in groups of 2 to 15 spaced at vertical intervals of 2 to $10 \mathrm{~mm}$. They are ordinarily complete and horizontal and flat to upwardly concave. In transverse sections the tabular intercepts are generally concentric, and the centers of concentricity range from axial to excentric in position.

Septal spines are rare, no more than $0.1 \mathrm{~mm}$ in length, and arise from the walls of the corallites. None were observed within the stereoplasmic thickening of the corallite walls.

Discussion.-The exact taxonomic position of the new species is in doubt. The general form of the corallites, the thick corallite walls, the nature of the tabulae, and the wrinkled epitheca are features that suggest placement in the Family Multithecoporidae as interpreted by Sokolov $(1950$, p. $28 ; 1955$, p. 199 ; 1962, p. 237). Although the species is referred pro- visionally to Multithecopora Yoh, it lacks the extreme thickening of the corallite walls and consequent narrowing of the visceral cavity to one-half to one-third the diameter of the corallite that characterize other species referred to this genus. The Amsden species is also distinguished by having septal spines and moderately abundant connections between corallites in the form of short connecting tubules and mural pores.

The Amsden species is also similar to species assigned to Neomultithecopora Lin (see interpretation by Kachanov, 1967) but differs in lacking extreme thickening of the corallite walls and in the absence of spines within the zone of stereoplasmic thickening.

Relationship to the Devonian genus Syringoporella Kettner is obscure because of the lack of detailed information on this genus. The Devonian forms appear to be characterized by much fewer tabulae, thicker connecting tubules, and they apparently lack the lamellar wall structure that characterizes the Carboniferous forms.

Multithecopora? amsdenensis is associated with foraminifers of Foraminiferal Zones 17 and 18, an interval of Chesterian age equivalent to $\mathbf{E}_{1}$ and $\mathbf{E}_{2}$ of the Namurian of Europe. In addition to its occurrence in the Moffat Trail Member of the Amsden Formation, it has also been found in the Big Snowy Group at Baldy Mountain in southwest Montana.

Occurrence and abundance.-Moffat Trail Limestone Member: collections $75(1), 77(1), 80(2)$, 105(1), Lincoln County; 122(1), 126(1), Teton County, Wyo.

Specimens.-Holotype, USNM 165177 ; paratypes, USNM 165178-184.

\section{Family THECOSTEGITIDAE Fromentel Genus DUNCANOPORA n. gen.}

Type species.-Duncanopora duncanae n. sp.

Diagnosis._Corallum phaceloid and cerioid, composed of cylindrical corallites that are joined at regular intervals in the corallum by lateral expansions or connecting structures. Regular connections within the corallum may be by simple increase in diameter of corallites, which crowds the corallites together to produce polygonal cross sections, or by connecting tubules or encircling deposits of sclerenchyme perforated by pores connecting adjacent corallites. Increase lateral. Tabulae sparse, ordinarily complete, horizontal, and slightly concave upward. Septal spines rare.

Discussion.-This new genus is referred to the 


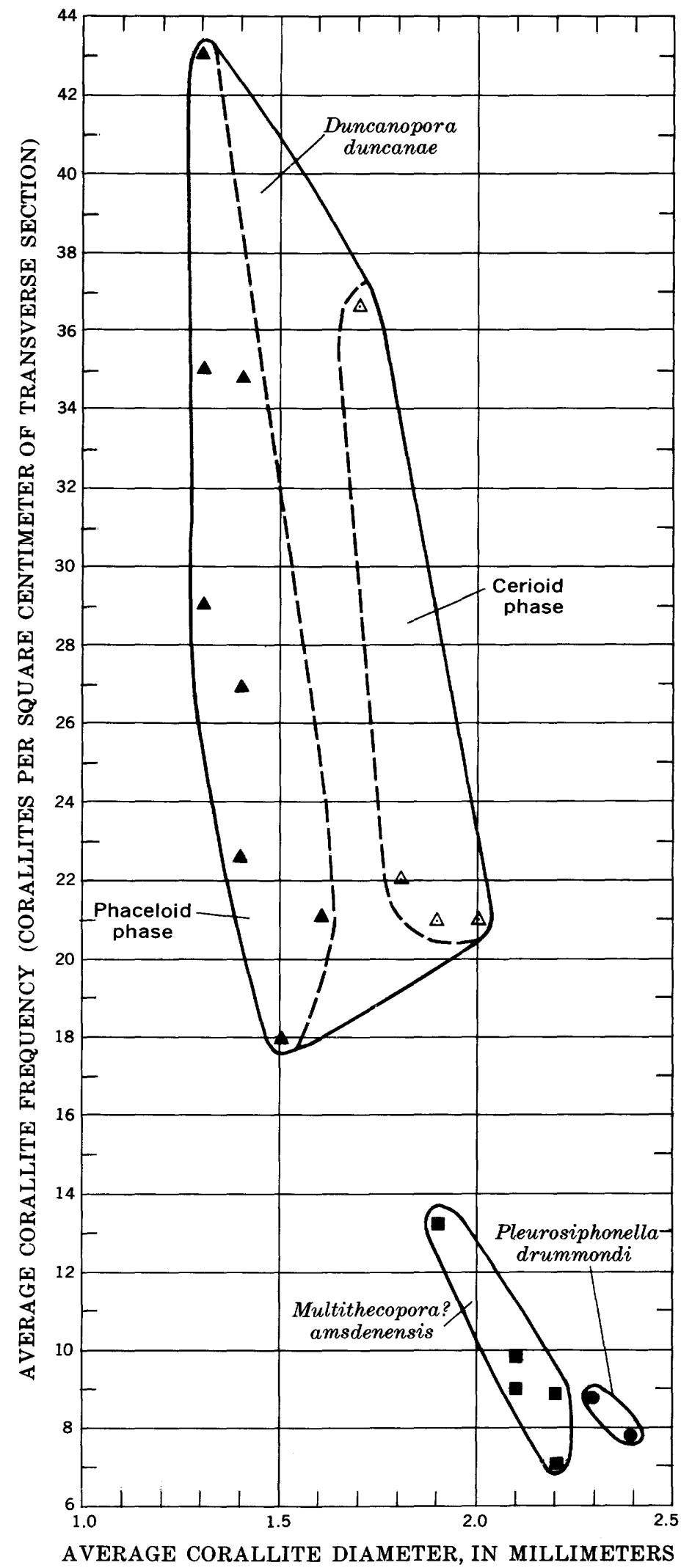

FiguRE 6.-Corallite diameter and frequency in syringoporoid corals from the Amsden Formation. Each diameter value represents the average of 20 measurements in a transverse section of a single corallum. Frequency values represent the average of 2 to 10 measurements in transverse sections of coralla. 
Family Thecostegitidae because of its regularly connected corallites, a feature characteristic of the family. It thus becomes the youngest representative of the Thecostegitidae, which was known previously only from the Silurian and Devonian. It appears to be most similar to Thecostegites Milne-Edwards and Haime but is distinguished from the latter by its more restricted communication between corallites through the connecting processes and by its sparse tabulae. It also differs in having offsets that arise laterally rather than from connecting structures. The tabulation of Duncanopora is similar to that of the Multithecoporidae as interpreted by Sokolov (1950), but the members of this family have extremely thickened walls and lack abundant and regular connections between corallites.

The Early Carboniferous genus Fuchungopora Lin $(1963$, p. 587,594$)$ has connecting structures similar to those of Duncanopora but has complex and abundant infundibular tabulae which sharply contrast with the simple tabulation of the Amsden forms. In North America, corals similar to Fuchungopora were described as Syringopora mccutcheonae by Wilson and Langenheim (1962, p. 515-516, pl. 89, figs. 11-13) on specimens from the Permian of Nevada.

Duncanopora is presently known only from its type species, which is described below. This species occurs in the Amsden Formation of western Wyoming, the Monroe Canyon Limestone of southeast Idaho (recorded as Tetraporinus? sp. by Sando in Dutro and Sando, 1963, p. 1982), the Surrett Canyon Formation of south-central Idaho, and the Green Ravine Formation of west-central Utah. The species was recorded as Hayasakaia? sp. by Sando in Sando and others (1969, p. E11, fig. 3). All known occurrences are in Zone $\mathrm{K}$ of Sando and others, (1969), an interval of Chesterian age (equivalent to $\mathrm{V} 3 \mathrm{c}_{\mathrm{s}}$ of the Viséan through $\mathrm{E}_{2}$ of the Namurian in Europe). Foraminifera in three of the Amsden samples indicate Foraminiferal Zones 17 and 18, which suggests that the species may be restricted to lower Namurian $\left(\mathrm{E}_{1}\right.$ and $\left.\mathrm{E}_{2}\right)$ equivalents.

\section{Duncanopora duncanae n. sp. Plate 10}

1963. Tetraporinus? sp. Sando in Dutro and Sando, p. 1982. 1969. Hayasakaia? sp. Sando in Sando and others, p. E11, fig. 3.

Description.-The Amsden specimens are all fragments of coralla; the largest and most complete specimen in the collections suggests that the species is characterized by a discoidal corallum about 5 to
$6 \mathrm{~cm}$ high and as much as $18 \mathrm{~cm}$ in diameter. Corallites are subparallel; they are subcylindrical except for regular layers in the corallum where they are expanded and cerioid. Cross sections of corallites range from circular to polygonal. Walls of individual corallites are distinct in cerioid levels of the corallum. Corallites are connected by mural pores in the cerioid layers of the corallum; these layers are commonly 2 to $5 \mathrm{~mm}$ thick. In the intervening phaceloid layers of the corallum, the corallites are connected by means of abundant short connecting tubules that have a vertical spacing of 1 to $3 \mathrm{~mm}$. Connecting tubules arise at regular levels in the corallum; they are augmented by sclerenchyme that forms imperfect platforms in most specimens. There are commonly two to four connecting canals in a single corallite at a given connecting tubule level. Increase is commonly multiple; as many as three offsets may arise at one level in a corallite.

Corallite diameters range from 1.1 to $1.7 \mathrm{~mm}$ in the phaceloid layers of the corallum; the variation within a given corallum is 0.3 to $0.5 \mathrm{~mm}$. The average diameter of phaceloid corallites ranges from 1.3 to $1.6 \mathrm{~mm}$, based on measurements of transverse sections of eight coralla (fig. 6). Corallite diameters in cerioid layers of the corallum range from 1.5 to $2.5 \mathrm{~mm}$; the variation within a given corallum is 0.5 to $0.9 \mathrm{~mm}$. The average diameter of cerioid corallites ranges from 1.7 to $2.0 \mathrm{~mm}$, based on measurements of transverse sections of four of the coralla in which phaceloid measurements were made (fig. 6). Average corallite frequency in phaceloid layers ranges from 18 to 43 corallites per square centimeter, measured in transverse sections of 8 coralla (fig. 6). In cerioid layers, the average corallite frequency is about the same as in phaceloid layers; it ranges from 21 to 36.6 corallites per square centimeter, measured in 4 coralla (fig. 6). Wall thickness is extremely variable, ranging from 0.1 to 0.7 $\mathrm{mm}$; the walls of most corallites are $0.3 \mathrm{~mm}$ or less in thickness. Concentric layers of stereoplasm are common in thickened walls of some corallites, but the diameter of the visceral cavity is ordinarily at least one-half to three fourths diameter of the corallite.

Tabulae are ordinarily complete, horizontal, and gently concave upward, although some may be slightly inclined from the horizontal and flat or gently convex upwards. They may be erratically distributed or in groups of 2 to 20 , separated by nontabulate intervals of 1 to $4 \mathrm{~mm}$; they appear to be concentrated at connecting tubule levels in 
some specimens. In transverse sections the tabular intercepts are concentric or nonconcentric, and where concentric the centers of concentricity range from axial to excentric in position.

Septal spines are ordinarily rare, no more than $0.1 \mathrm{~mm}$ in length, and arise from the walls of the corallites.

Occurrence and abundance.-Moffat Trail Limestone Member: collections 76(1), 77(3), 80(2), $88(1), 91(1), 92(1 ?), 93(1 ?), 104(2), 109(1 ?)$, Lincoln County; 126(1), Teton County, Wyo.

Specimens.-Holotype, USNM 165184 ; paratypes, USNM 165185-197.

\section{REFERENCES CITED}

Bassler, R. S., 1950, Faunal lists and descriptions of Paleozoic corals: Geol. Soc. America Mem. 44, 294 p., 20 pls.

Branson, C. C., 1937, Stratigraphy and fauna of the Sacajawea formation, Mississippian, of Wyoming: Jour. Paleontology, v. 11, no. 8, p. 650-660, pl. 89.

Branson, E. B., and Greger, D. K., 1918, Amsden formation of the east slope of the Wind River Mountains of Wyoming and its fauna: Geol. Soc. America Bull., v. 29, no. 6, p. 309-327, pls. 18, 19.

Chi, Y. S., 1931, Weiningian (Middle Carboniferous) corals of China: Paleontologia Sinica, ser. B, v. 12, pt. 5, 70 p., illus.

Chudinova, I. I., 1970, Novyye tabulyaty iz paelzoya Zakavkaz'ya [New tabulate corals from the Paleozoic of Transcaucasia] in Astrova, G. G., and Chudinova, I. I. eds., Novyye vidy paleozoiskikh mshanok i korallov [New species of Paleozoic Bryozoa and corals]: Moscow, Akad. Nauk SSSR, p. 97-111, illus.

Dobrolyubova, T. A., 1948, I.zmenchivost korallov filogeneticheskogo ryada Dibunophyllum bipartitum (McCoy)Caninia okensis Stuck. [Variability of corals in the phylogenetic series Dibunophyllum bipartitum (McCoy) -Caninia okensis Stuck.]: Akad. Nauk. SSR, Izvestiya, ser. biol., p. 149-169, illus.

1970, Novyye odinochnyye rugozy iz nizhnego karbona Russkoy platformy [New solitary Rugosa from the lower Carboniferous of the Russian Platform] in Astrova, G. G., and Chudinova, I. I., editors, Novyye vidy paleozoiskikh mshanok i korallov [New species of Paleozoic Bryozoa and corals]: Moscow, Akad. Nauk SSSR, p. 121-134, illus.

Dutro, J. T., Jr., and Sando, W. J., 1963, New Mississippian formations and faunal zones in Chesterfield Range, Portneuf quadrangle, southeast Idaho: Am. Assoc. Petroleum Geologists Bull., v. 47, no. 11, p. 1963-1986, 6 figs.

Easton, W. H., 1962, Carboniferous formations and faunas of central Montana: U.S. Geol. Survey Prof. Paper 348, 126 p., 14 pls., 1 text fig.

Fischer von Waldheim, G., 1829, in Eichwald, C. E. von, Zoologia Specialis quam espositis animalibus tum vivis, tum fossilibus potissimum rossiae in universum, et poloniae in specie, in usum lectionum: 314 p., 5 pls., Vilna.

Fomichev, V. D., 1939, Typ Kishechnopolostnye-Coelenterata: in Gorsky, I. I., ed., Atlas rukovodyashchikh form iskopaemykh faun SSSR [Atlas of the leading forms of the fossil faunas of USSR] tom 5, Sredniy i verkhniy otdely kamennougol'noy sistemy [Middle and Upper Carboniferous], Tsentral'nyy Nauchno-issledovatel'skiy Geologo-razvedochniy Institut, Leningrad, p. 50-64, pls. 6-11.

Fromentel, E. de, 1861, Introduction a l'étude des polypiers fossiles: Paris, 357 p.

Hill, Dorothy, 1940, A monograph of the Carboniferous rugose corals of Scotland, pt. 3: Palaeontographical Soc. London, p. 115-204.

- 1956, Rugosa in Moore, R. C., ed., Treatise on invertebrate paleontology, pt. F, Coelenterata: Geol. Soc. America and Kansas Univ. Press, p. 233-324.

Hill, Dorothy, and Stumm, E. C., 1956, Tabulata in Moore, R. C., ed., Treatise on invertebrate paleontology, pt. F, Coelenterata: Geol. Soc. America and Kansas Univ. Press, p. $444-477$.

Hudson, R. G. S., 1941, On the Carboniferous corals- $Z a$ phrentis carruthersi sp. nov. from the Mirk Fell beds and $i$ ts relation to the $Z$. delanouei species-group: Yorkshire Geol. Soc. Proc., v. 24, pt. 4, p. 290-311, pls. 21, 22, 1 fig.

Kachanov, Ye. I., 1967, Novyye dannyye o korallakh roda Neomultithecopora iz nizhnego karbona Novoy Zemli i Urala [New data on corals of the genus Neomultithecopora from the lower Carboniferous of Novaya Zemlya and the Urals]: Paleont. Zhur. for 1967, no. 3, p. 25-32, illus. [Am. Geol. Inst. translation].

Kato, Makoto, 1963, Fine skeletal structures in Rugosa: Hokkaido Univ. Fac. Sci. Jour., ser. 4, v. 11, no. 4, p. 571-630, 3 pls., 19 text figs.

- 1966, Note on some Carboniferous coral generaClisaxophyllum, Clisiophyllum (Neoclisiophyllum), Zaphrentoides, Stylidophyllum, and Actinocyathus: Japanese Jour. Geology and Geography, v. 37, nos. 2-4, p. 93-104, pl. 3.

Lane, N. G., and Martin, R. A., 1966, Redescription of Chaetetes milleporaceus Milne-Edwards and Haime, 1851: Jour. Paleontology, v. 40, no. 3, p. 651-654, pl. 80.

Lin, Pao-yü, 1963, Some Carboniferous and Permian Tabulata of South China: Acta Palaeontologica Sinica, v. 11, no. 4, p. 579-596, illus. [In Chinese with Russian summary.]

Lonsdale, W., 1845, Descriptions of some characteristic corals of Russia in Murchison, R. I., Verneuil, Edouard, and Keyserling, Alexander, The Geology of Russia in Europe and the Ural Mountains, v. 1, p. 591-634, illus., London.

Macqueen, R. W., Bamber, E. W., and Mamet, B. L., 1972, Lower Carboniferous stratigraphy and sedimentology of the southern Canadian Rocky Mountains: 24th Internat. Geol. Cong., Montreal, 1971, Guidebook Excursion C17, 62 p., 7 figs.

Martin, W., 1809, Petrificata derbiensa; or, figures and descriptions of petrifactions collected in Derbyshire: 102 p., illus., Wigan.

McCoy, F., 1849, On some new genera and species of Paleozoic corals and Foraminifera: Annals and Mag. Nat. History, 2d. ser., v. 3, p. 1-20.

Michelin, J. L. H., 1840, in Gervais, P., Astrée, Astraea, Dict. Sci. Nat. Paris, Supplement 1, p. 481-487.

Minato, M., and Kato, M., 1965, Waagenophyllidae: Hokkaido Univ. Fac. Sci. Jour., ser. 4, v. 12, nos. 3-4, 241 p., illus. 
Moore, R. C., and Jeffords, R. M., 1945, Description of Lower Pennsylvanian corals from Texas and adjacent states: Texas Univ. Pub. 4401, p. 63-208, figs. 1-214, pl. 14.

Nelson, S. J., 1960, Mississippian lithostrotionid zones of the southern Canadian Rocky Mountains: Jour. Paleontology, v. 34 , no. 1 , p. 107-126, pls. 21-25, 3 text figs.

1962, Analysis of Mississippian Syringopora from the southern Canadian Rocky Mountairis: Jour. Paleontology, v. 36, no. 3, p. 442-460, illus.

Orbigny, Alcide d' 1849, Note sur des polypiers fossiles: Paris, 12 p.

Phillips, J., 1836, Illustrations of the geology of Yorkshire, pt. 2, The Mountain Limestone district: London, 253 p., illus.

Pickett, John, 1966, Lower Carboniferous coral faunas from the New England district of New South Wales: New South Wales Geol. Survey Mem., Paleontology, no. 15, 38 p., illus. [1967].

Sando, W. J., 1961, Morphology and ontogeny of Ankhelasma, a new Mississippian coral genus: Jour. Paleontology, v. 35 , no. 1 , p. $65-81$, pls. $17,18,13$ text figs.

1965, Revision of some Paleozoic coral species from the western United States: U.S. Geol. Survey Prof. Paper 503-E, p. E1-E38, pls. 1-15, 7 text figs.

1967, A technique for studying early ontogeny in solitary rugose corals: Jour. Paleontology, v. 41, no. 5, p. 1291-1293.

Sando, W. J., Gordon, Mackenzie, Jr., and Dutro, J. T., Jr., 1974, Stratigraphy and geologic history of the Amsden Formation (Mississippian and Pennsylvanian) of Wyoming: U.S. Geol. Survey Prof. Paper 848-A. (In press.)

Sando, W. J., Mamet, B. L., and Dutro, J. T., Jr., 1969, Carboniferous megafaunal and microfaunal zonation in the northern Cordillera of the United States: U.S. Geol. Survey Prof. Paper 613-E, 29 p., 1 pl., 7 text figs.

Smith, Stanley, 1916, The genus Lonsdaleia and Dibunophyllum rugosum (McCoy) : Geol. Soc. London Quart. Jour., v. 71 , p. 218-272, pls. 17-21.
Sokolov. B. S., 1939, Stratigraphical value and types of Chaetetidae of the Carboniferous of the USSR: Akad. Nauk SSSR Doklady (foreign ed.), v. 23, no. 4, p. 409-412.

1950, Khetetidy karbona severo-vostochnoy Ukrainy i sopredel'nykh oblastey [Carboniferous chaetetids of the northeastern Ukraine and adjacent areas]: Vses. Neft. Nauchno-Issled. Geol--Razved. Inst. Trudy, nov. ser., vyp. 27, 143 p., illus.

1955, Tabulyaty Paleozoya Evropeiskoy Chasti SSSR [Paleozoic tabulates from the European USSR]: Trudy VNIGRI, nov. ser., vyp. 85, 525 p. illus.

- editor, 1962, Osnovy paleontologii, spravochnik dlya paleontologov i geologov SSSR; [t. 2], Gubki, arkheotsiaty, kishechnopolostnye, chervi [Fundamentals of paleontology, v. 2, sponges, archeocyathids, coelenterates] : Moscow, Akad. Nauk SSSR, 485 p., illus.

Sowerby, J., 1814, The mineral conchology of Great Britain: v. 1, p. 165,166, pl. 72 , London.

Stouder, R. E., 1938, Chester rocks of Meade, Hardin, and Breckenridge Counties, Ky.: Am. Assoc. Petroleum Geologists Bull., v. 22, no. 3, p. 267-284, 3 text figs.

U.S. Geological Survey, 1965, Geological Survey Research 1965: U.S. Geol. Survey Prof. Paper 525-A, 376 p., illus.

1966, Geological Survey Research 1966: U.S. Geol. Survey Prof. Paper 550-A, 385 p., illus.

Wilson, E. C., and Langenheim, R. L., Jr., 1962, Rugose and tabulate corals from Permian rocks in the Ely quadrangle, White Pine County, Nevada: Jour. Paleontology, v. 36 , no. 3 , p. $495-520$, pls. $86-89,4$ text figs.

Yoh, S. S., 1927, On a new genus of syringoporoid coral from the Carboniferous of Chihli and Fengtien Provinces: Geol. Soc. China Bull., v. 5, p. 291-293, pl. 1. 



\section{INDEX}

[Italic page numbers indicate descriptions and major references]

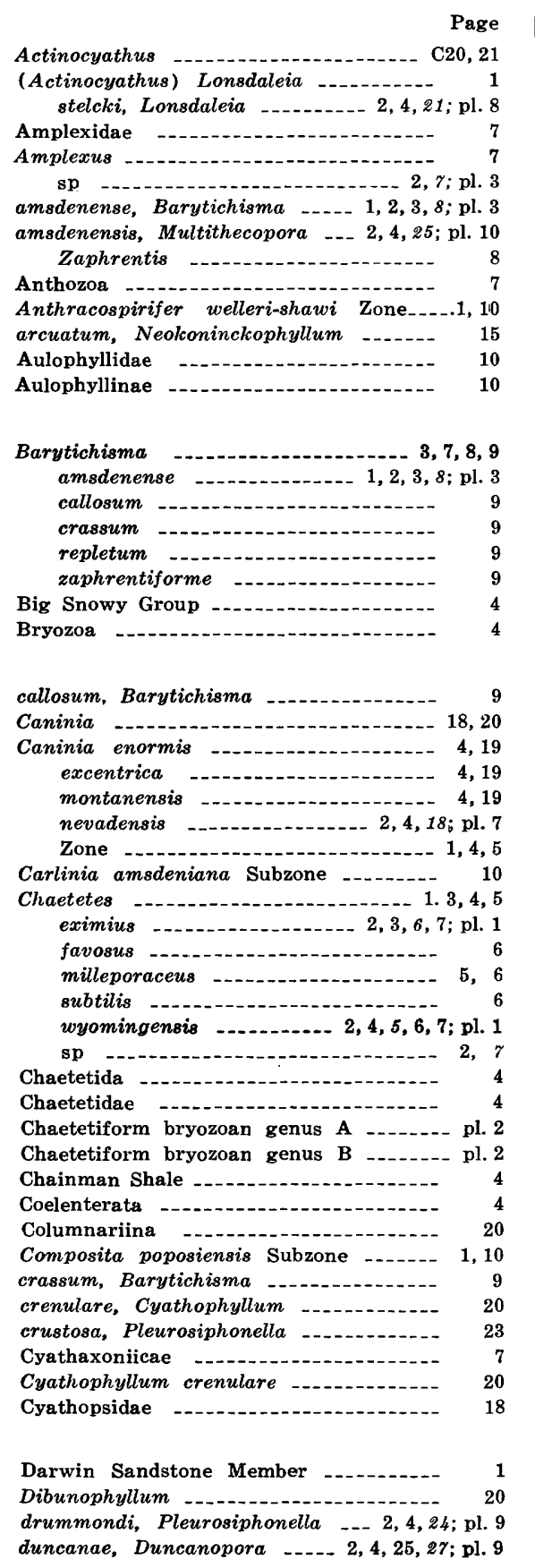

Duncanopora duncanae

enormis, Caninia C25, 27 Madreporites

$$
\text { (floriformis) }
$$
$2,4,25,27 ;$ pl. 10

Etherington Formation

excentrica, Caninia

eximius, Chaetetes _........ 2, 3,6, 7; pl. 1

Fasciculiamplexus

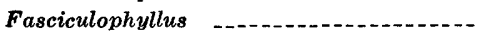

favosus, Chaetetes

(floriformis), Erismatolithus

Fuchungopora Madreporites -

gracile, Neokoninckophyllum

Great Blue Limestone
Green Ravine Formation

Halls Creek Limestone

hamatilis, Neokoninckophyllum $-2,3,10,15$,

Hapsiphyllidae

18; pls. 4,5

Hayasakaia sp

27

Horseshoe Shale Member _......... 1, 7, 10

Hydrozoa -

inconstans, Neokoninckophyllum 2, 3, 15; pl. 6

Ipciphyllum -... 20

Koninckophyllum _.-.-1 20

Lithostrotionella stelcki

Livingstone Formation

Lonsdaleia -

(Actinocyathus) - stelcki

Lonsdaleiidae -

Lonsdaleiinae - 20

Madreporites (floriformis), Erismatolithus -...-- 20

magnussoni, Pleurosiphonella milleporaceus, Chaetetes _...... 5, 6

Moffat Trail Limestone Member....... 1, 5, 6

Monroe Canyon Limestone -........ 4, 24

montanensis, Caninia _......... 4, 19

Mount Head Formation -...... 24

Multithecopora -.............. 25 amsdenensis Multithecoporidae

Nemistium -...- 20

Neokoninckophyllum arcuatum _....... 15 gracile
Page

Neokoninckophyllum-Continued hamatilis _..._ C2, 3, 10, 15, 18; pls. 4, 5 Zone -.......... 1 inconstans _............ 2, 3, 15; pl. 6 simplex _... sp A - $A$

Neomultithecopora _................ 25 nevadensis, Caninia _....... 2, 4, 18; pl. 7

Ochre Mountain Limestone

Pleurosiphonella -.-.-_- 23 crustosa magnussoni -.virginica ......... 24

Ranchester Limestone Member _..... 6, 7 repletum, Barytichisma -...-...- 9 Rugosa -

St. Louis Limestone simplex, Neokoninckophyllum _..._... 15, 18 stelcki, Lithostrotionella _._... 21 Lonsdaleia (Actinocyathus) -- 2, 4, 21; pl. 8 Streptelasmatina -.....Stylidophyllum -.... 20 subtilis, Chaetetes - 6

Surrett Canyon Formation Syringopora distans drummondi magnussoni _................... 24 mccutcheonae pachytheca virginica - Syringoporella -..-1- 25 Syringoporidae - Systematic paleontology

Tabulata _...

Tabulatesare

$\begin{array}{lll}\text { Tetraporinus } \mathrm{sp} & 27 \\ \text { Thecostegites } & & 27\end{array}$

Thecostegites

Turbinatocaninia sp

virginica, Pleurosiphonella

Wentzelophyllum wyomingensis, Chaetetes $-.-2,4,5,6,7 ; \mathrm{pl} .1$

Yokoyamaella

20

Zaphrenticae -..._...- 10 zaphrentiforme, Barytichisma _-.....- 9

Zaphrentis amsdenensis _..........- 8 Zaphrentites _.. Zoantharia Zone $\mathrm{K}$ 



\section{PLATES $1-10$}

Contact photographs of the plates in this report are available, at cost, from the U.S. Geological Survey Library, Federal Center, Denver, Colorado 80225. 


\section{PLATE 1}

FIGURES 1-3. Chaetetes wyomingensis n. sp. (p. 5).

Holotype, USNM 165080, collection 78 .

1. Transverse thin section (X 10); USNM 165080b.

2. Longitudinal thin section (X 10); USNM 165080a.

3. Transverse thin section (X 100); USNM $165080 \mathrm{~b}$.

4-7. Chaetetes cf. C. eximius Moore and Jeffords (p. 6).

USNM 165085, collection 17.

4. Transverse thin section (X 100); USNM 165085e.

5. Longitudinal thin section ( $X 10)$; USNM $165085 f$.

6. Transverse thin section (X 10); USNM 165085e.

7. Longitudinal thin section ( $X 10)$; USNM 165085c. 
PROFESSIONAL PAPER 848-C PLATE 1

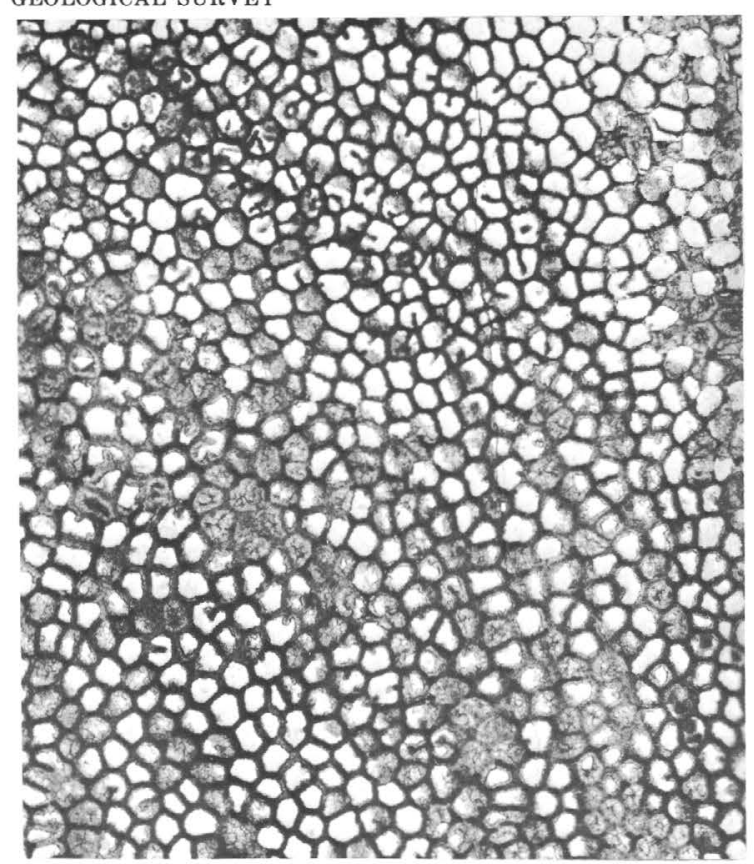

1

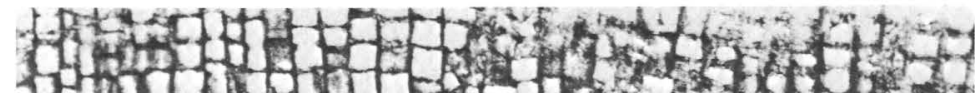

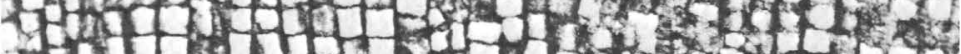

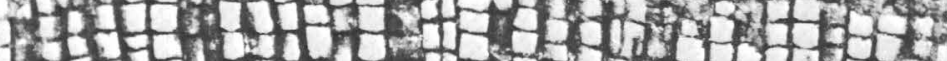

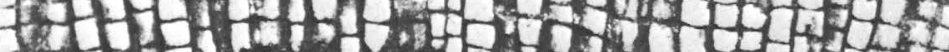
- Le

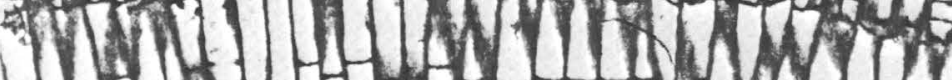

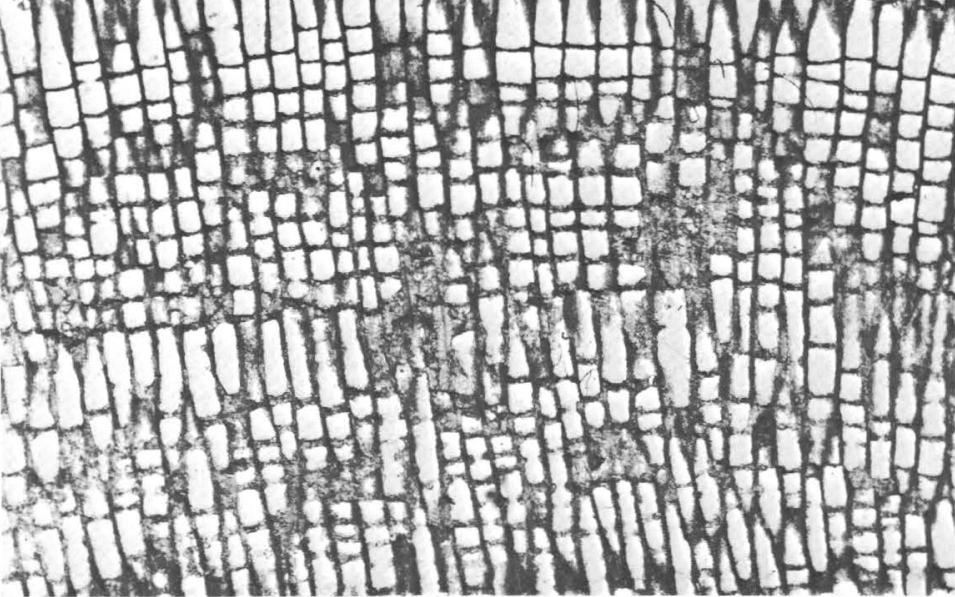
2

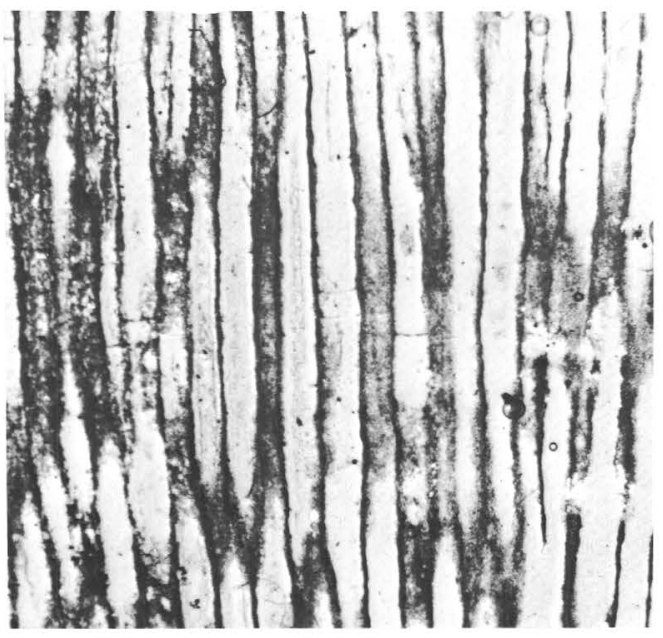

5

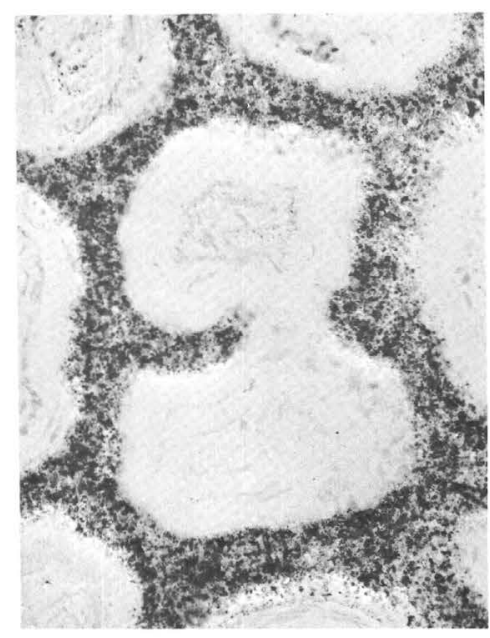

4

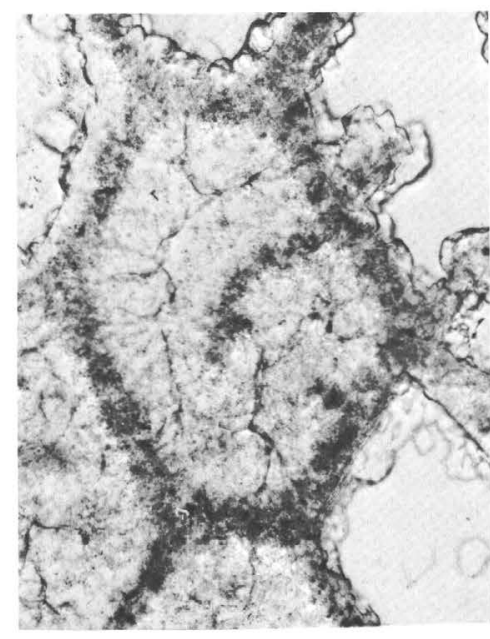

3

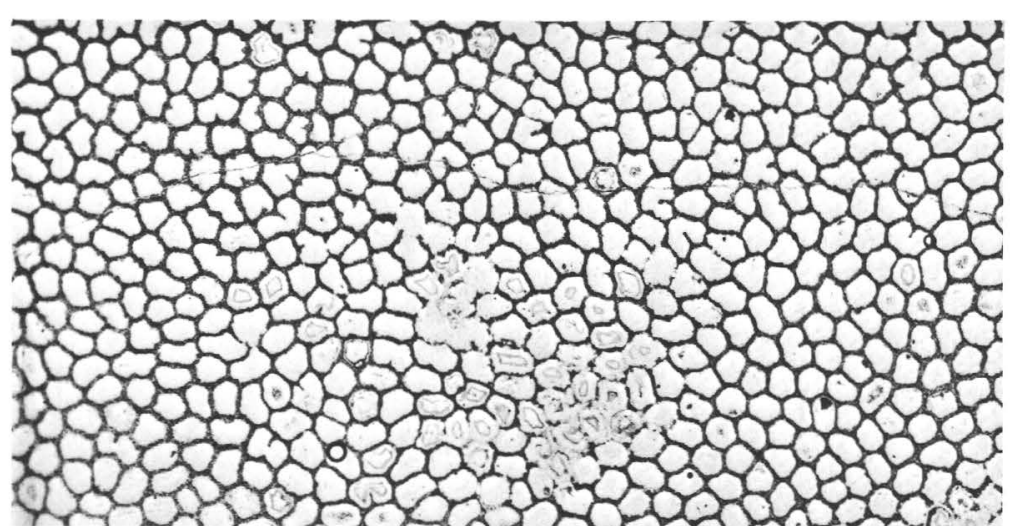

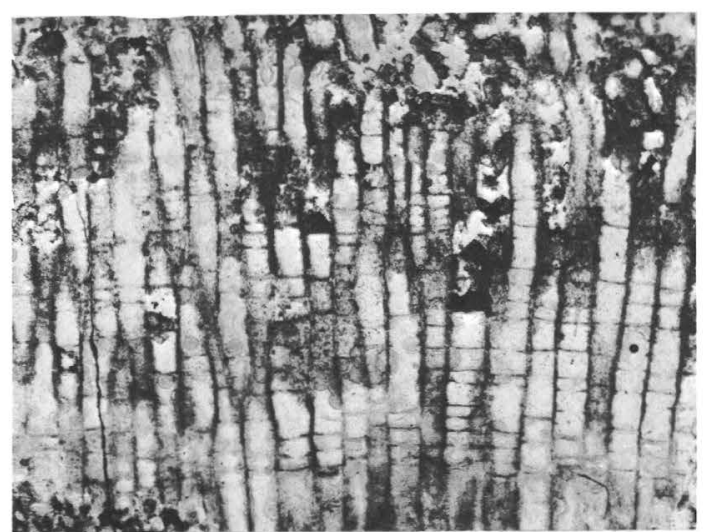

7

CHAETETES 


\section{PLATE 2}

Figures 1-3. Chaetetiform bryozoan genus A

USNM 165087; collection 76.

1. Transverse thin section (X 10); USNM 165087a.

2. Transverse thin section ( $X$ 100); USNM 165087a.

3. Longitudinal thin section (X 10); USNM 165087b.

4-6. Chaetetiform bryozoan genus B

USNM 165086, collection 94.

4. Transverse thin section (X 10); USNM 165086a.

5. Transverse thin section ( $X$ 100); USNM 165086a.

6. Longitudinal thin section (X 10); USNM 165086b. 
GEOLOGICAL SURVEY

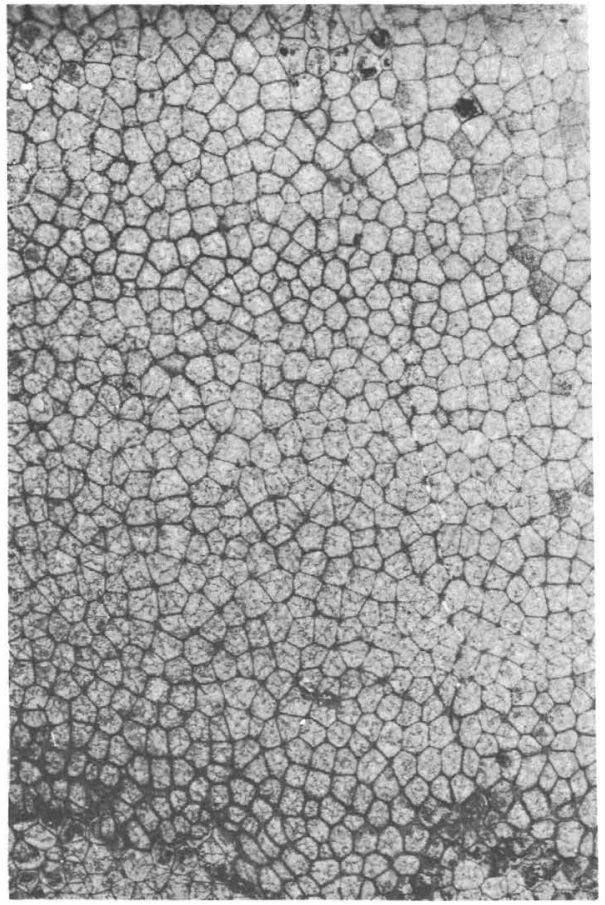

1

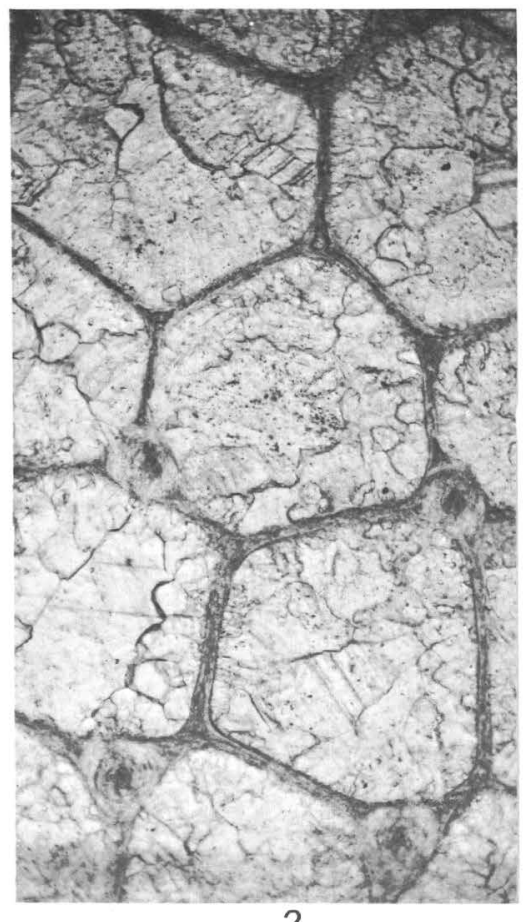

2

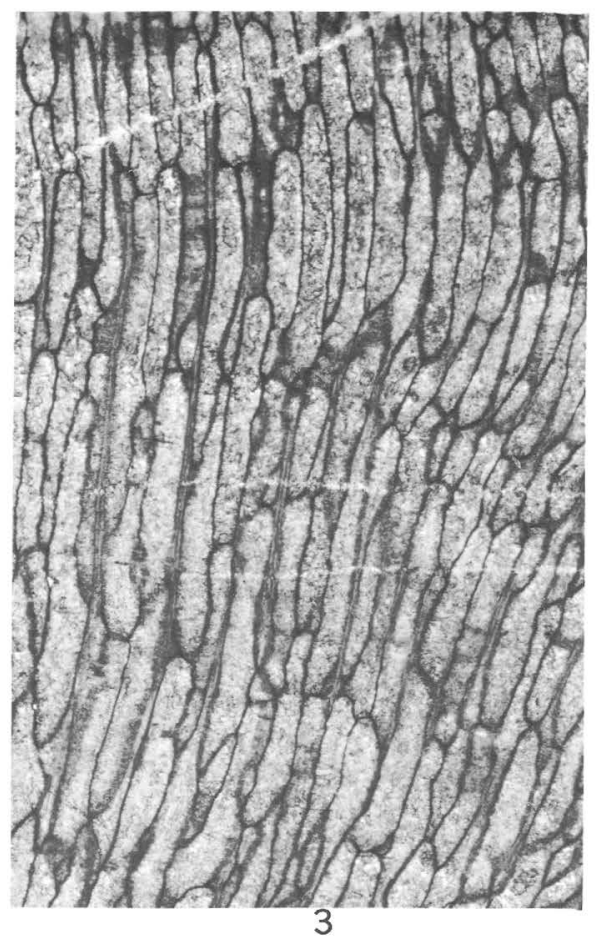

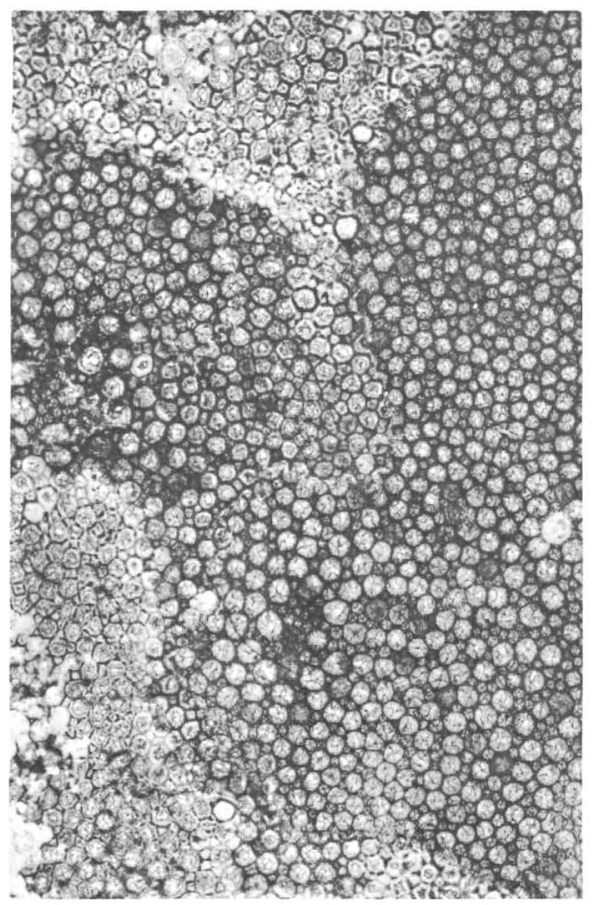

4

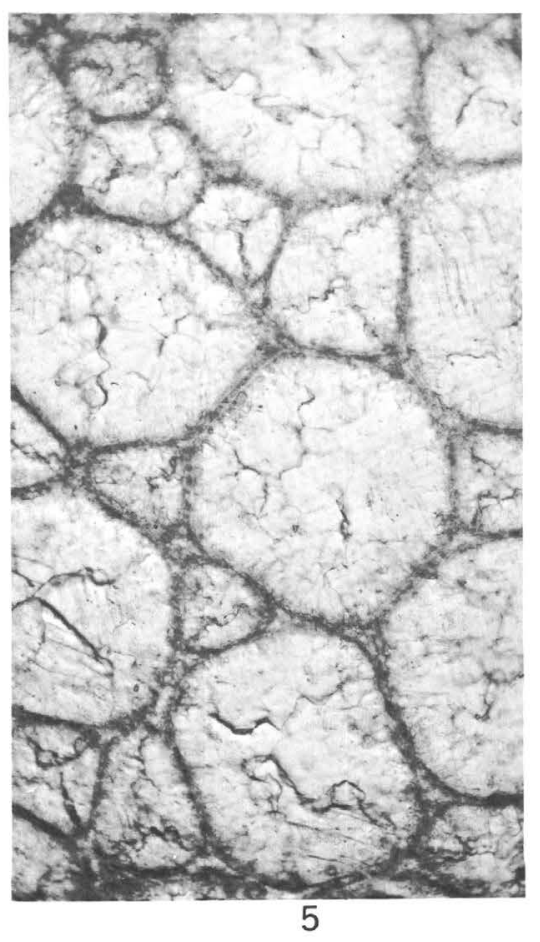

CHAETETIFORM BRYOZOANS

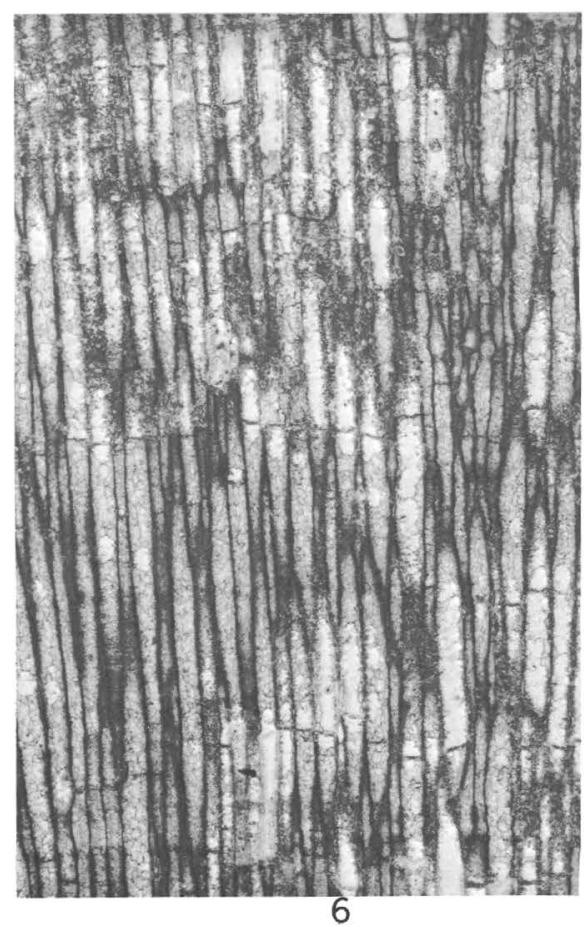




\section{PLATE 3}

Figures 1-25. Barytichisma amsdenense (Branson and Greger) (p. 8).

1-18. Lectotype, UM 2663, collection 36.

1-5. Drawings of serial transverse peel sections ( $\mathbf{X}$

$10)$; dark stippling represents sparry calcite; light stippling represents stereoplasm.

6, 7. Drawings of serial transverse peel sections (X 2) continuous with sections in figs. $1-5$.

8-14. Serial transverse thin sections (X 2) continuous with sections in figs. 6 and 7.

15. Calicular view ( $\mathrm{X} 1$ ).

16. Cardinal side view (X 1$)$.

17. Counter side view ( $\mathrm{X} 1)$.

18. Alar side view (X 1 ).

19. Longitudinal thin section (X 2); paralectotype, UM 2663, collection 36a.

20-25. Serial transverse thin sections (X 4); topotype, USNM 165091a-f, respectively, collection 27.

26-29. "Amplexus" sp. indet. (p. 7).

Serial transverse thin sections (X 2), USNM 165088a, c-e, respectively, collection 41 . 
GEOLOGICAL SURVEY

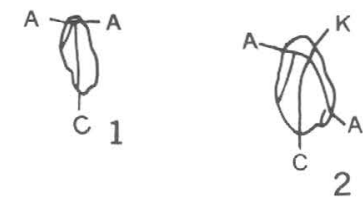<smiles>c1ccc(C23CC4CC(CC2C4)C3)cc1</smiles>

$\frac{1}{4} 8$

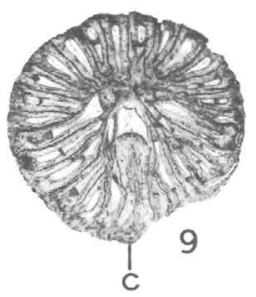

3
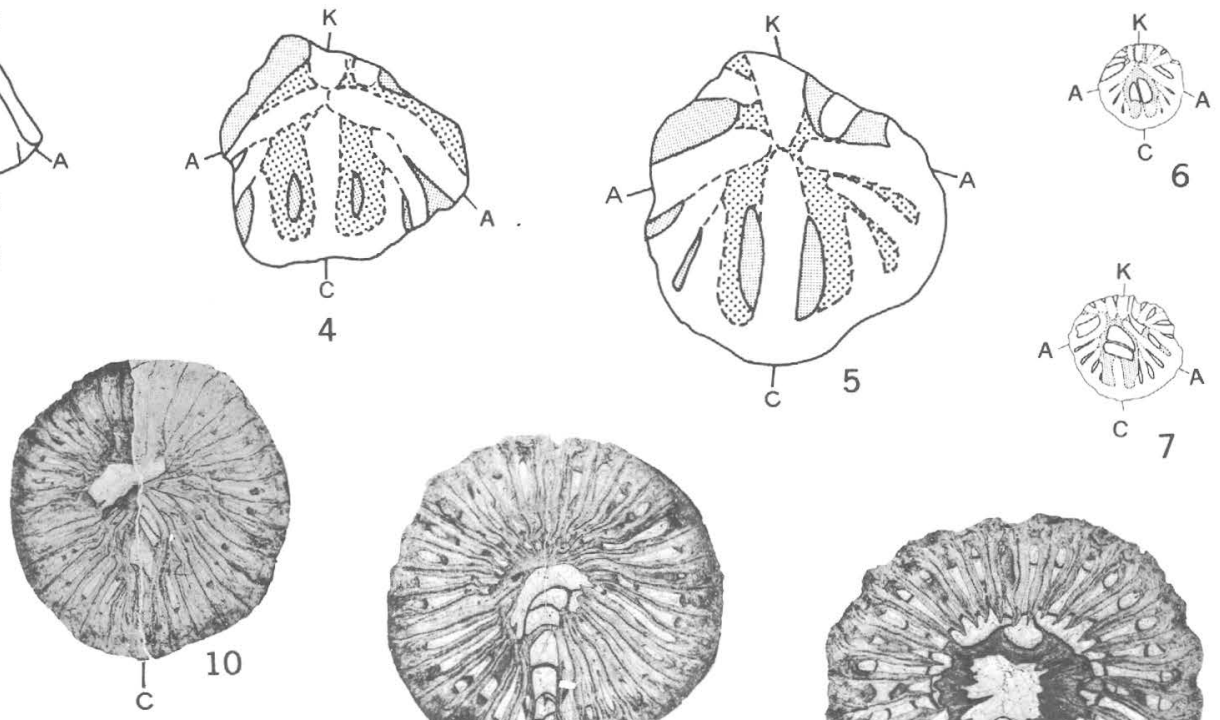

C 7
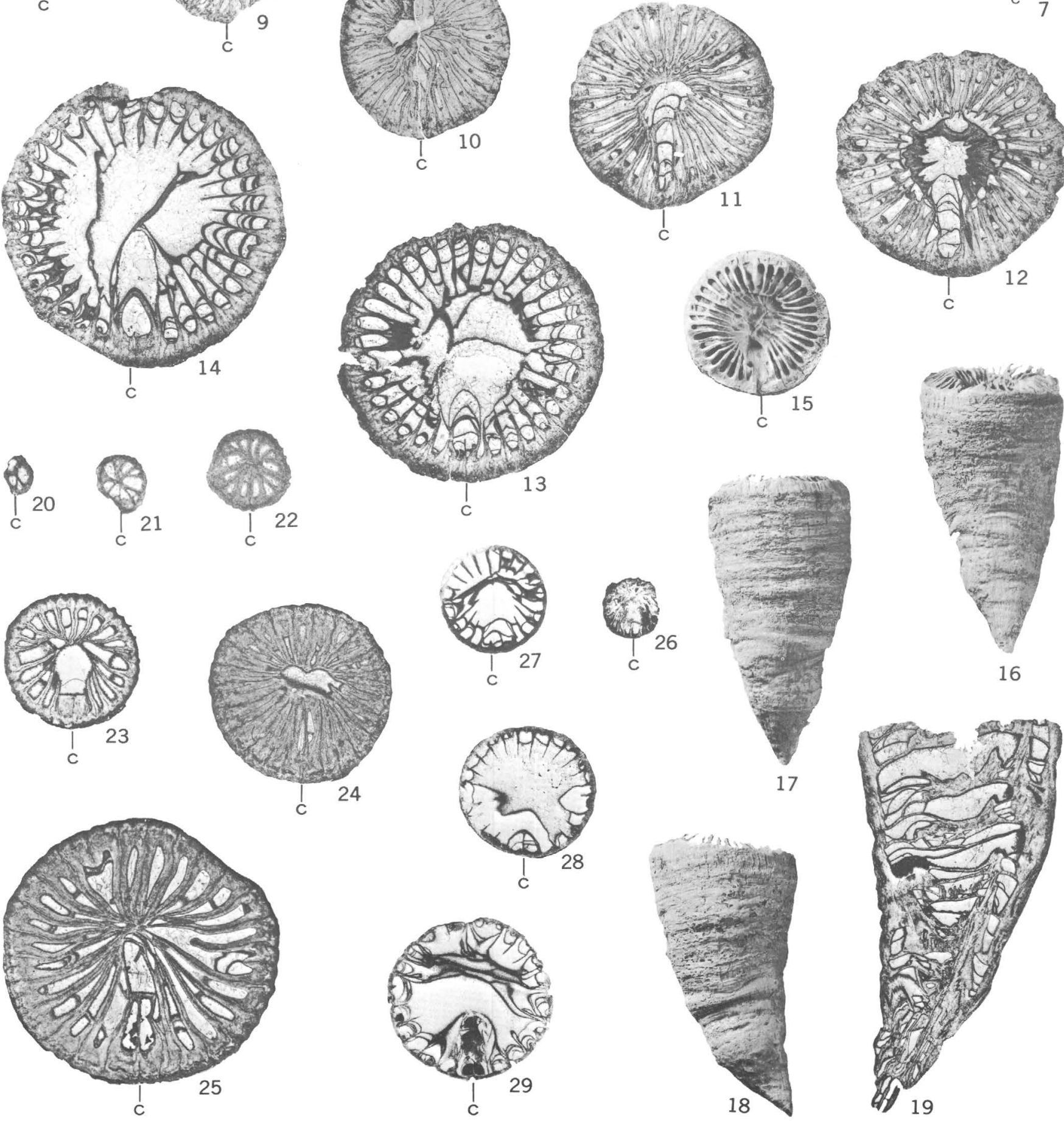

16

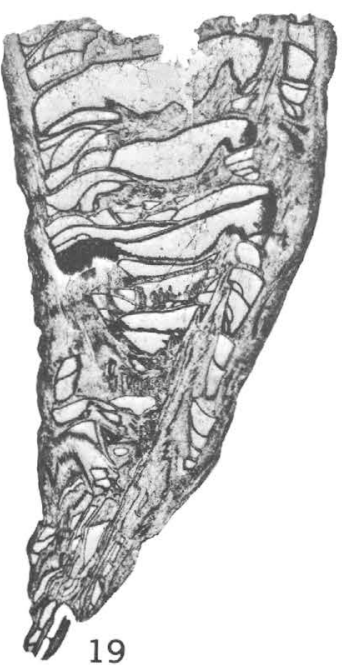

BARYTICHISMA AMSDENENSE (BRANSON AND GREGER) AND "AMPLEXUS" SP. INDET. 


\section{PLATE 4}

FIGURES 1-19. Neokoninckophyllum hamatilis n. sp. (p. 10).

Holotype, USNM 165095, collection 3.

1-8. Drawings of serial transverse peel sections (X 10); USNM 165095a-h, respectively. Figs. 1 and 2, brephic stage; figs. $3-8$, neanic stage.

9-15. Serial transverse thin sections (X 2) continuous with sections shown in figs. 1-8, USNM 165095i-0, respectively. Figs. 9-11, neanic stage; figs. 12-15, ephebic stage.

16. External view of counter side (X 1 ).

17. External view of right alar side (X 1).

18. External view of left alar side (X 1$)$.

19. External view of cardinal side (X 1). 
GEOLOGICAL SURVEY
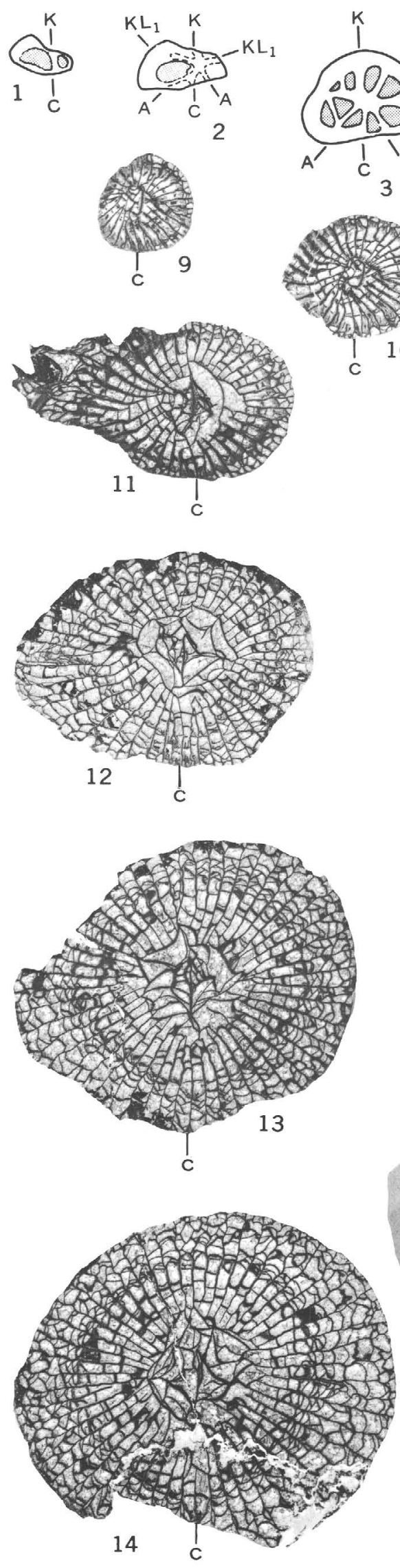

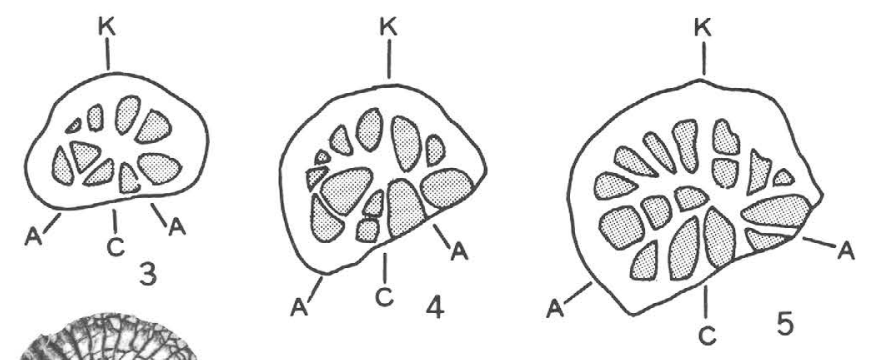

PROFESSIONAL PAPER 848-C PLATE 4
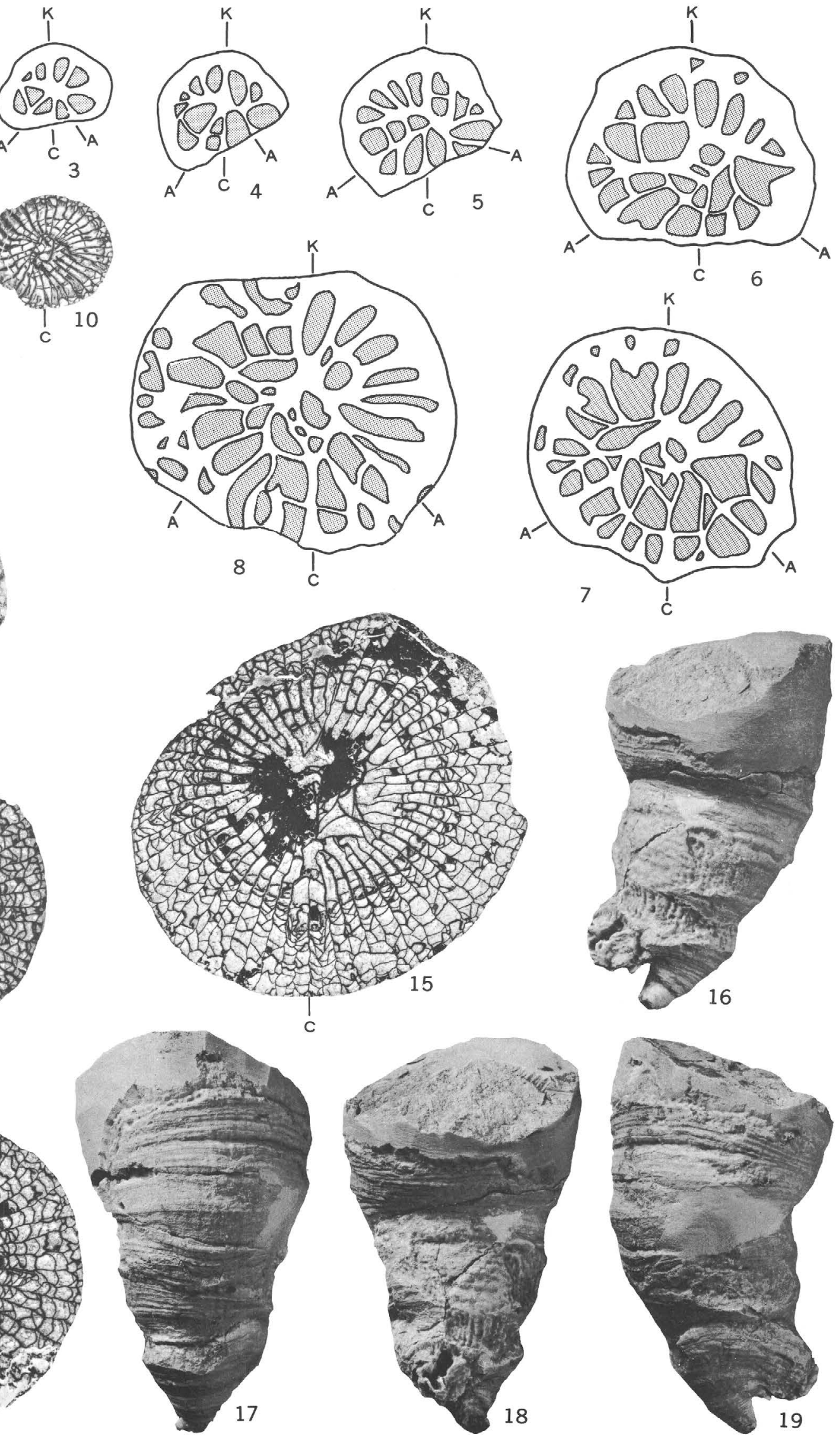

NEOKONINCKOPHYLLUM HAMATILIS N. SP. 


\section{PLATE 5}

FIgURES 1-12. Neokoninckophyllum hamatilis n. sp. (p. 10).

1-3. Paratype, USNM 165097; collection 3.

1. Longitudinal thin section (X 2), neanic stage; USNM 165097a.

2,3. Transverse thin sections ( $X$ 2), neanic stage; USNM 165097b, c, respectively.

4-7. Paratype USNM 165102; collection 1.

4,5. Transverse thin sections (X 2), ephebic stage; USNM 165102a, b, respectively.

6. Longitudinal thin section ( $\mathrm{X} 2$ ), ephebic stage; USNM 165102c.

7. External view (X 1), ephebic stage.

8, 9. Right and left alar side ( $\mathrm{X}$ 1) views, paratype; USNM 165096. Collection 3.

10. Calicular view (X 2); paratype. USNM 165106; collection 2.

11, 12. Paratype. USNM 165098. Collection 3.

11. Longitudinal thin section ( $\mathrm{X} 2$ ), ephebic stage; USNM 165098a.

12. Transverse thin section ( $\mathrm{X} 2$ ), ephebic stage; USNM $165098 \mathrm{~b}$. 


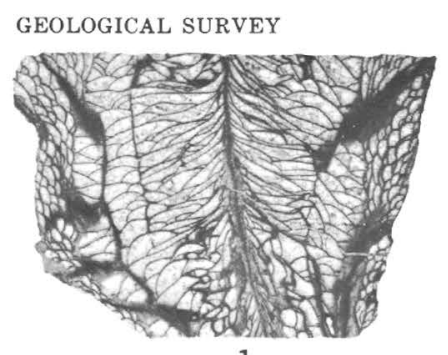

1
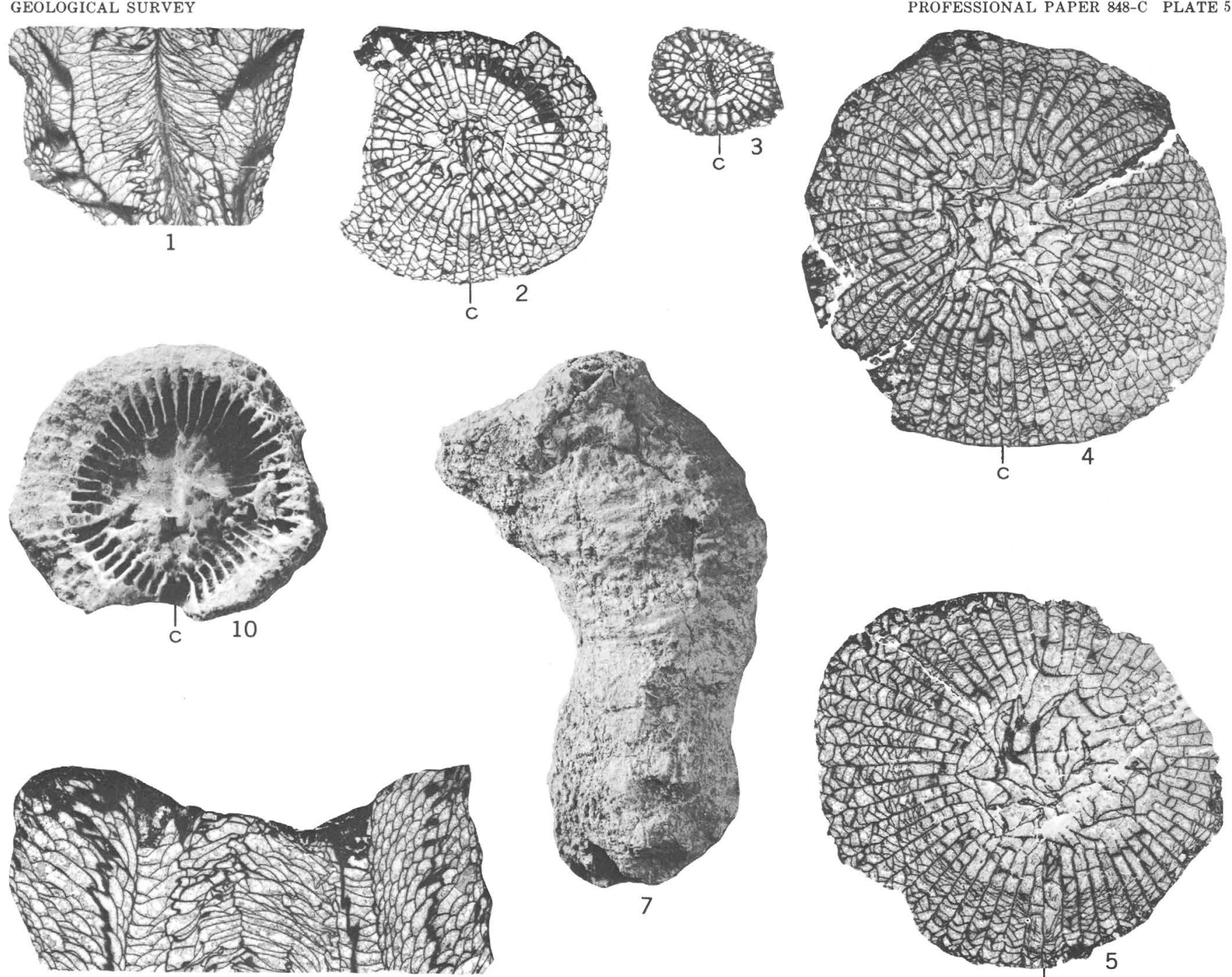

11
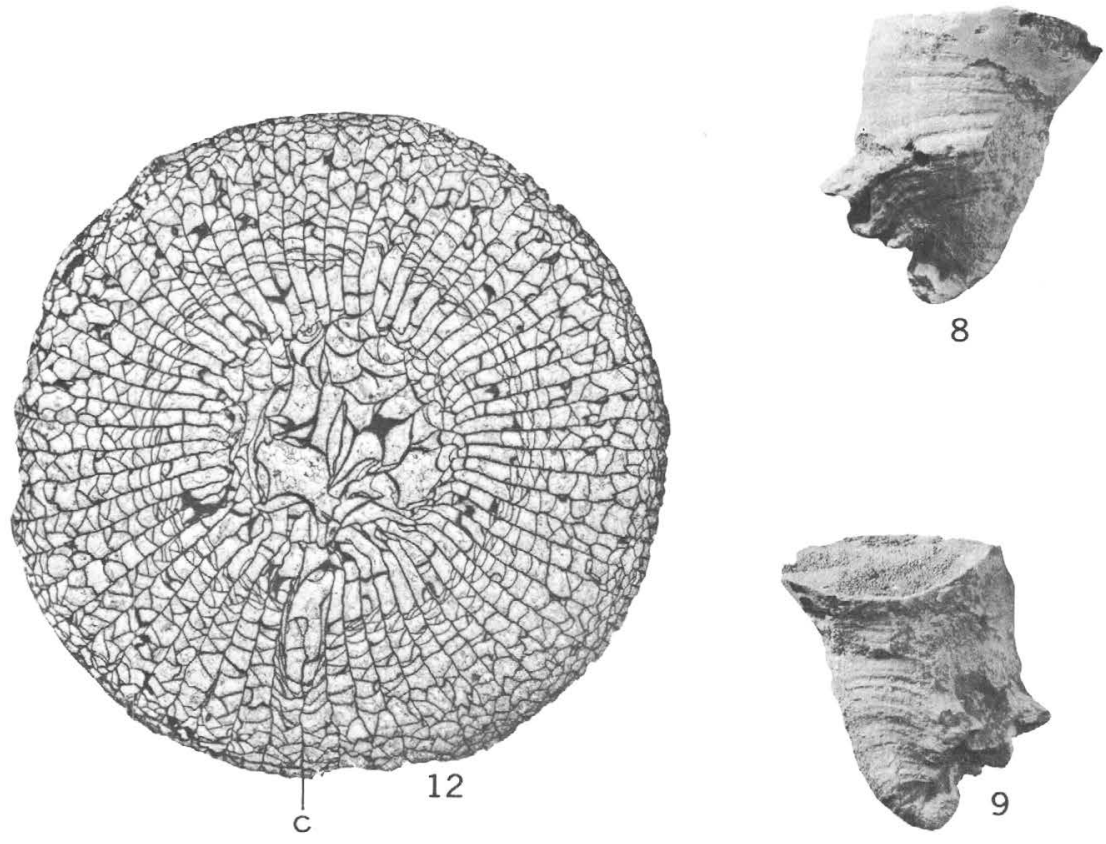

NEOKONINCKOPHYLLUM HAMATILIS N. SP.
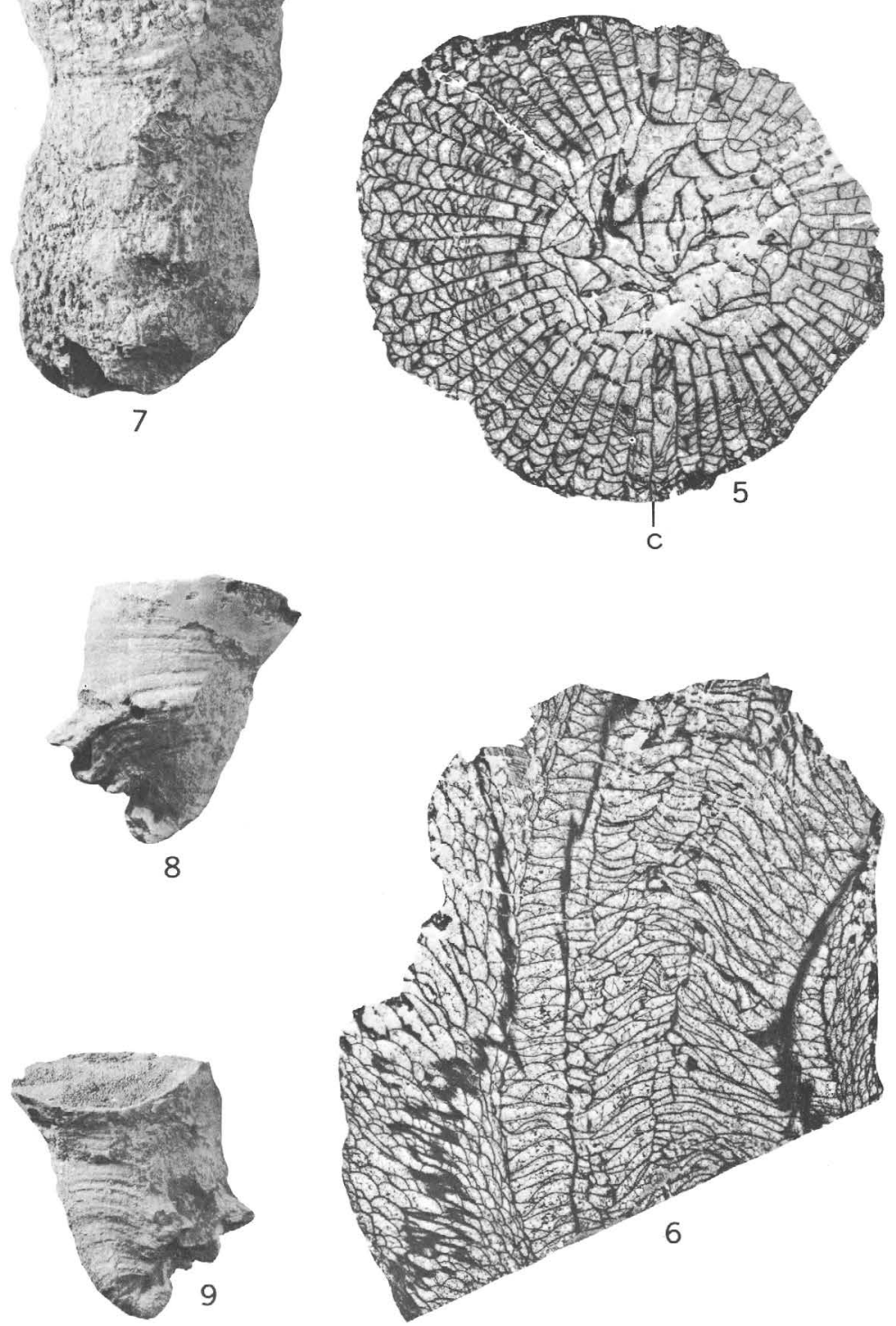


\section{PLATE 6}

[All figures, collection 7

Figures 1-33. Neokoninckophyllum inconstans n. sp. (p. 15).

1-7. Holotype. USNM 165109.

1-6. Serial transverse thin sections ( $\mathrm{X}$ 2). USNM $165109 a-f$, respectively.

7. External side view (X 1).

8-17. Paratype. USNM 165114.

8-11. Serial transverse peel sections (X 10). USNM $165114 \mathrm{a}-\mathrm{d}$, respectively.

12-16. Serial transverse thin sections (X 3) continuous with sections shown in figs. 8-11. USNM $165114 \mathrm{e}-\mathrm{i}$, respectively.

17. External side view (X 1$)$.

18-24. Paratype USNM 165115.

18,19. Serial transverse thin sections (X 10). USNM $165115 \mathrm{a}, \mathrm{b}$, respectively.

20-24. Serial transverse thin sections (X 3) continuous with sections shown in figs. 18 and 19. USNM $165115 \mathrm{c}-\mathrm{g}$, respectively.

25. Transverse thin section (X 2) paratype. USNM 165117a.

26, 27. Paratype. USNM 165118, (X 2).

26. Longitudinal thin section. USNM 165118a.

27. Transverse thin section. USNM $165118 \mathrm{~b}$.

28. External oblique side view (X 2), paratype. USNM 165113.

29. External side view (X 1), paratype. USNM 165111.

30. External side view (X 1), paratype. USNM 165112.

31. Transverse thin section (X 2), paratype. USNM 165120a.

32, 33. Paratype. USNM 165116 (X 2).

32. Transverse thin section. USNM 165116a.

33. Longitudinal thin section. USNM $165116 \mathrm{~b}$. 

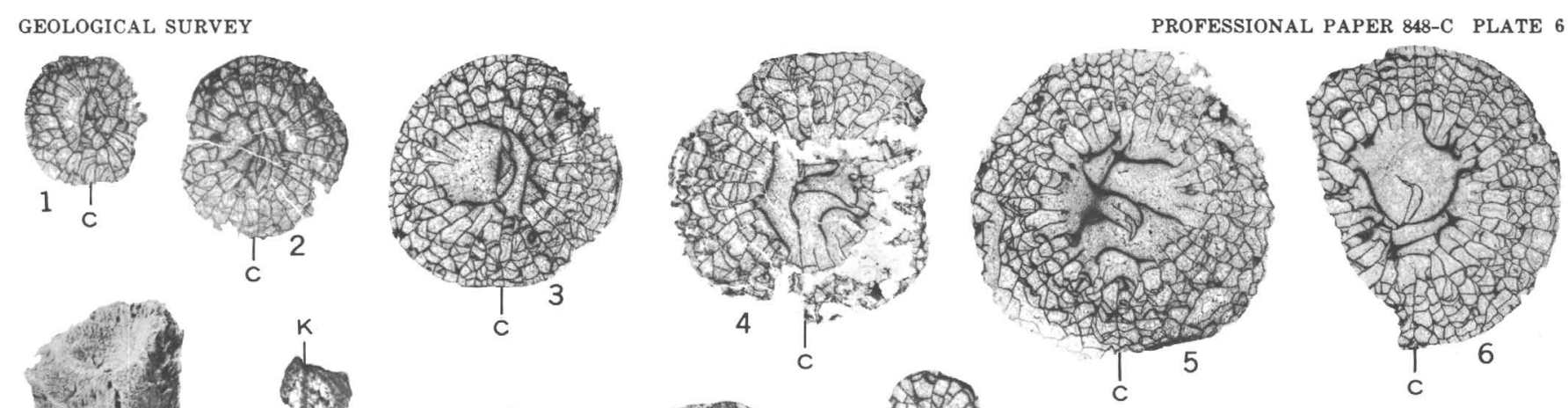

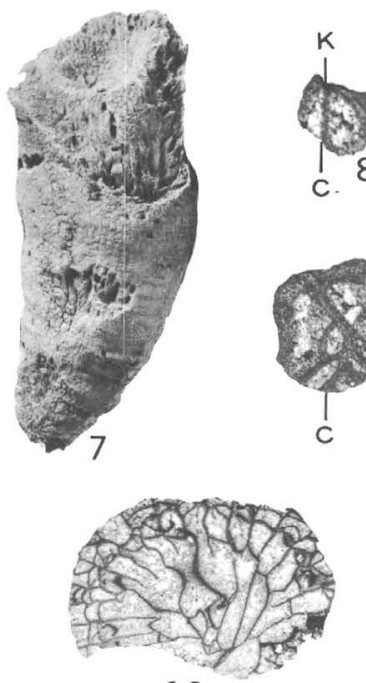

16

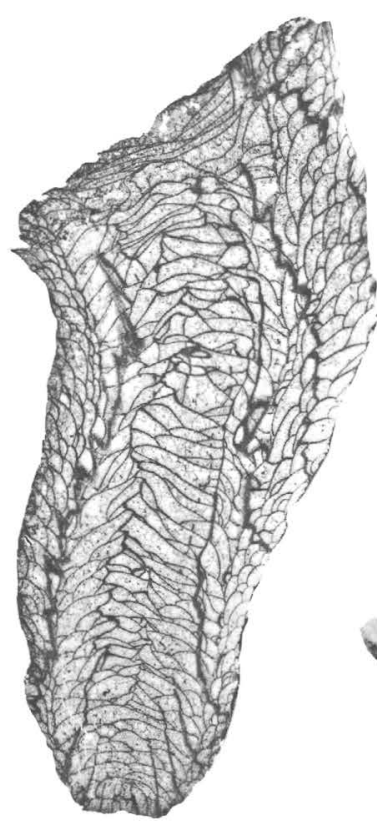

26

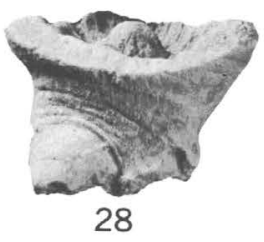

28

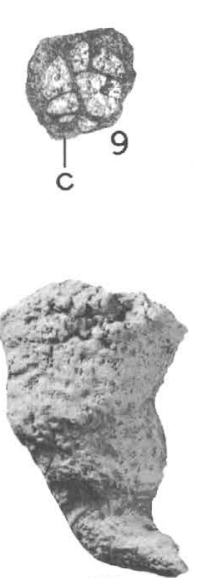

17

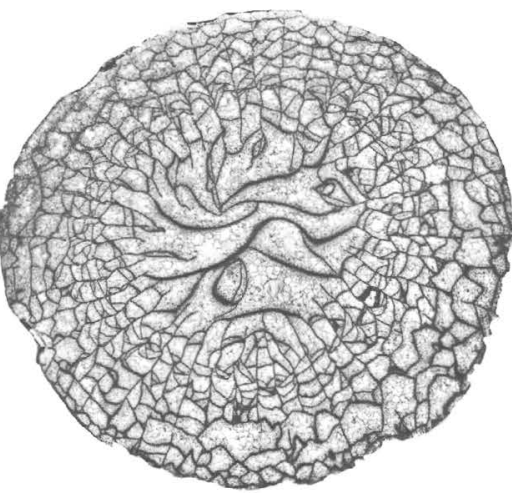

25

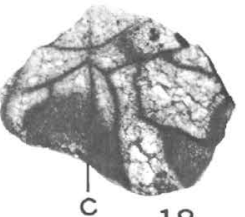

18

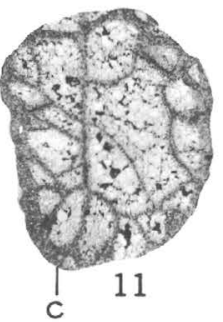

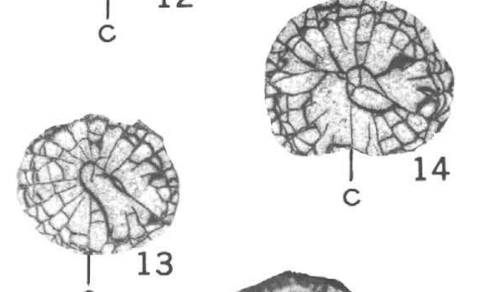
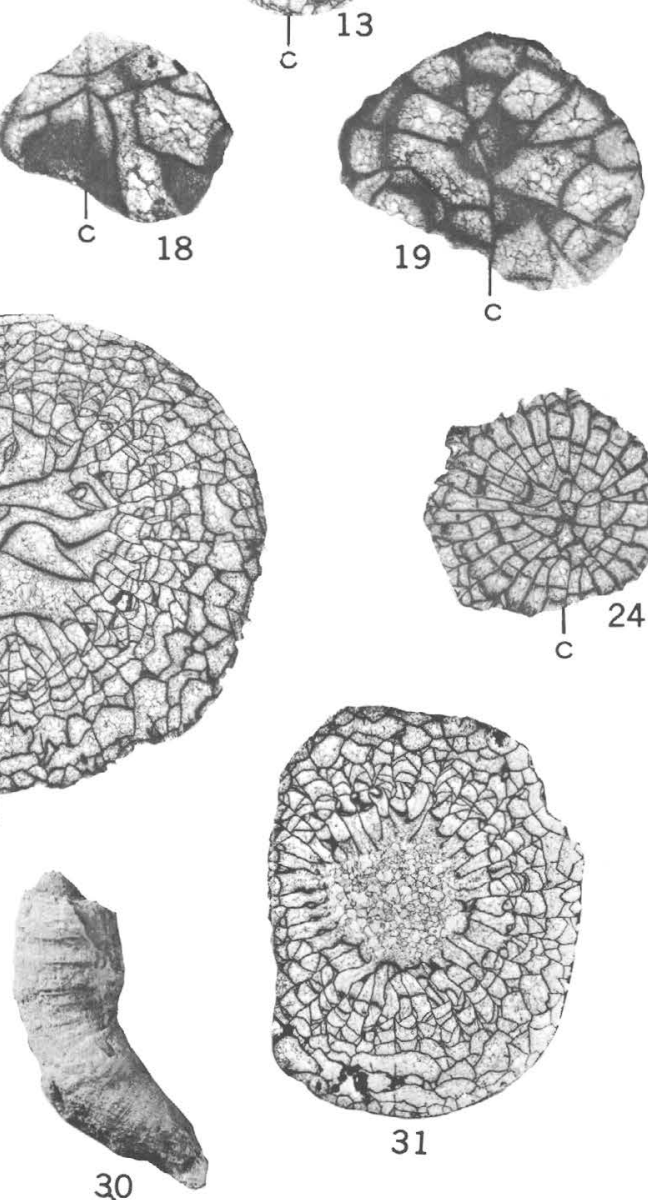

in

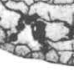

31

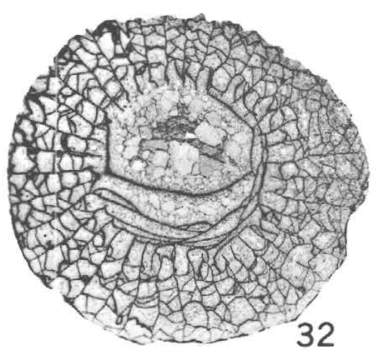

32
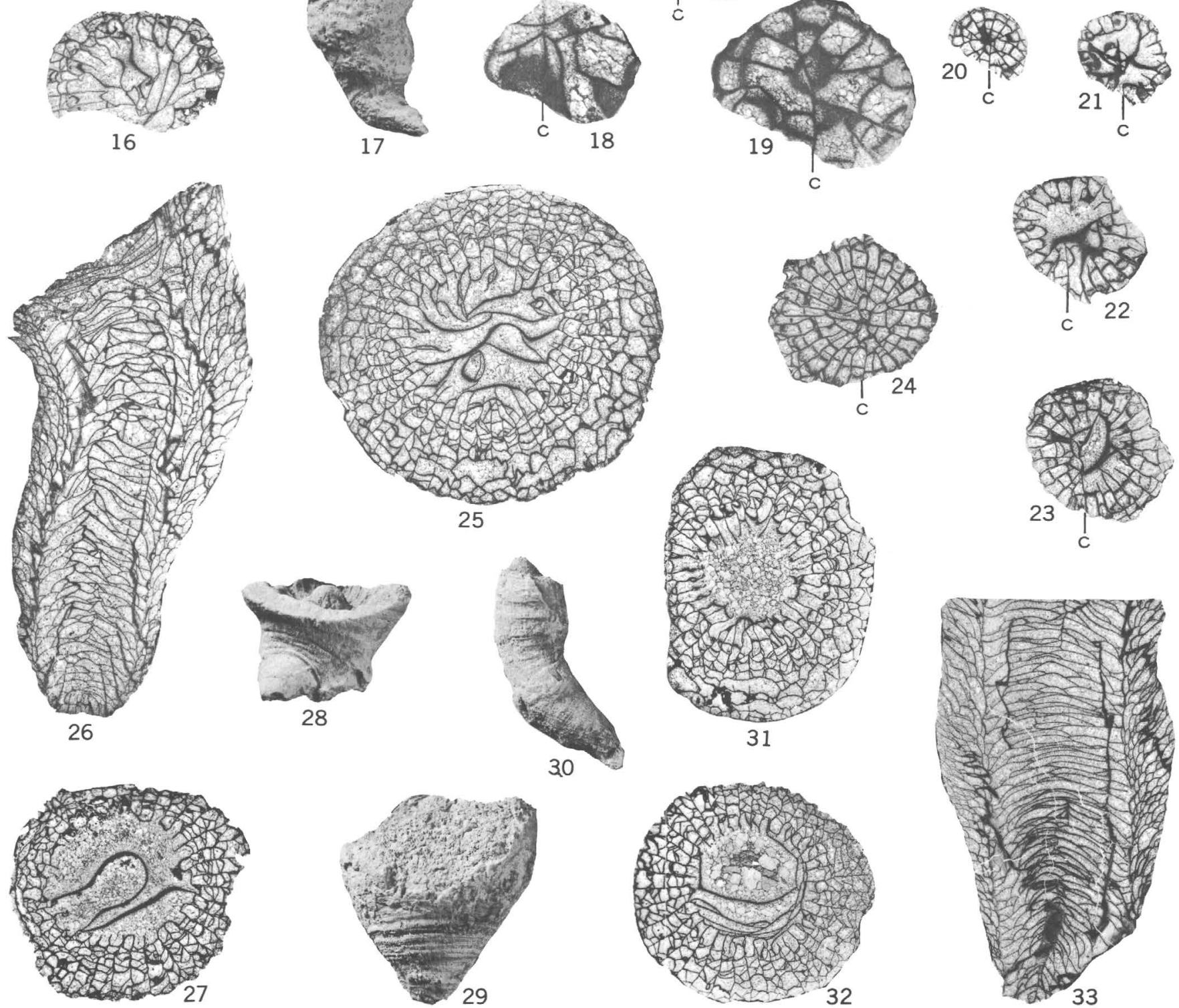

NEOKONINCKOPHYLLUM INCONSTANS N. SP. 


\section{PLATE 7}

Figures 1-8. Caninia cf. C. nevadensis (Meek) (p. 18).

1,2. USNM 165123, collection 104 .

1. Transverse thin section (X 1); ephebic stage; USNM $165123 a$.

2. Longitudinal thin section (X 1); ephebic stage; USNM $165123 \mathrm{~b}$.

3. Transverse thin section ( $\mathrm{X}$ 1); ephebic stage; USNM 165128a, collection 105 .

4,5. Transverse thin sections (X 2); early ephebic and neanic stages, respectively; USNM 165125a, b, collection 76 .

6,7. USNM 165126, collection 105 .

6. Transverse thin section ( $\mathrm{X} 1$ ); ephebic stage; USNM $165126 \mathrm{a}$

7. Longitudinal thin section (X 1); ephebic stage; USNM $165126 \mathrm{~b}$.

8. Transverse thin section (X 2); early ephebic stage; USNM $165132 \mathrm{a}$, collection 109 .

9-19. Turbinatocaninia? sp. (p. 19).

9. Longitudinal thin section (X 2) ; USNM 165147a; collection 105.

10,11. USNM 165148; collection 105 .

10. Longitudinal thin section (X 2); USNM 165148a.

11. Transverse thin section (X 2); USNM 165148b.

12. Transverse thin section (X 2); USNM 165145a; collection 105.

13. Transverse thin section (X 2); USNM 165151; collection 105.

14. Transverse thin section (X 2); USNM 165150a; collection 105.

15. Longitudinal thin section (X 2); USNM 165144a; collection 105.

16. Transverse thin section (X 2); USNM 165149a; collection 105.

17. Transverse thin section (X 2); USNM 165143a; collection 105.

18. Transverse thin section (X 2); USNM 165142a; collection 105.

19. Longitudinal thin section (X 2); USNM 165159a; collection 73. 
GEOLOGICAL SURVEY
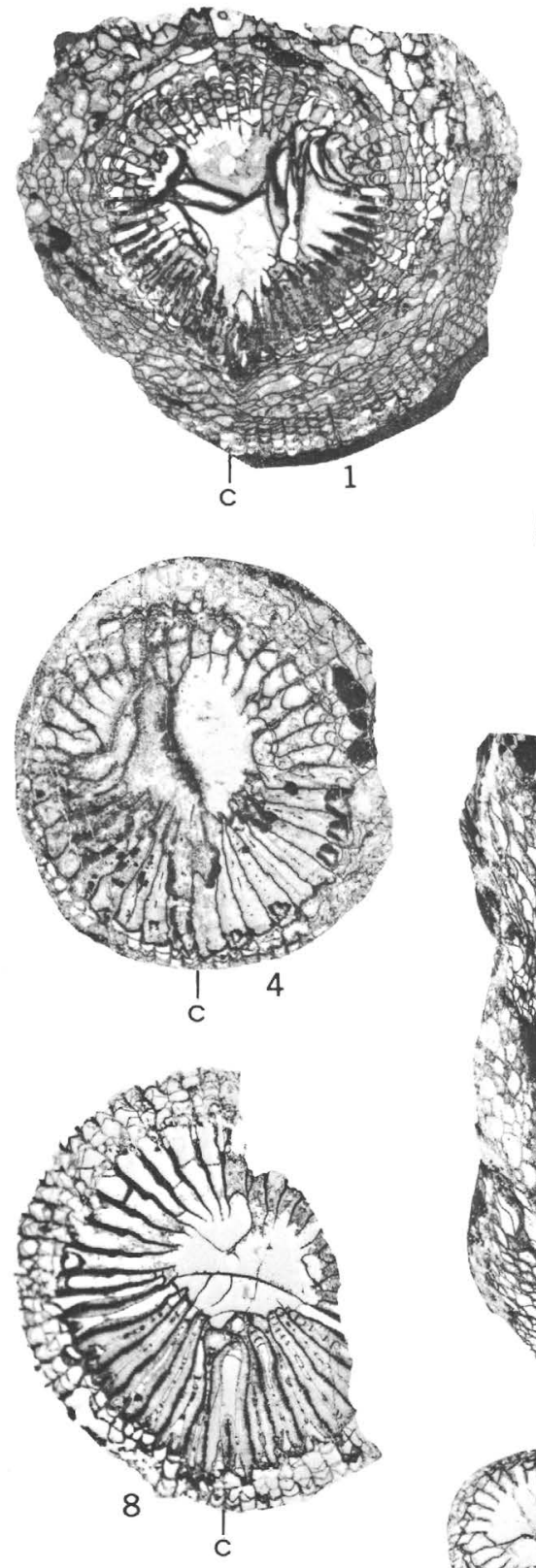

wive

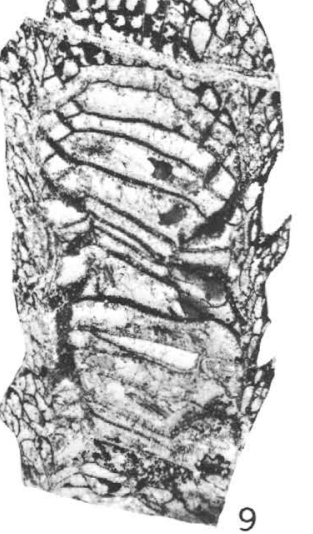

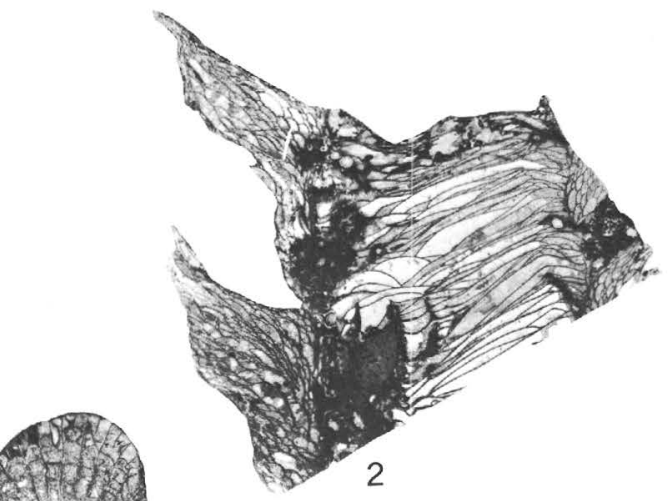

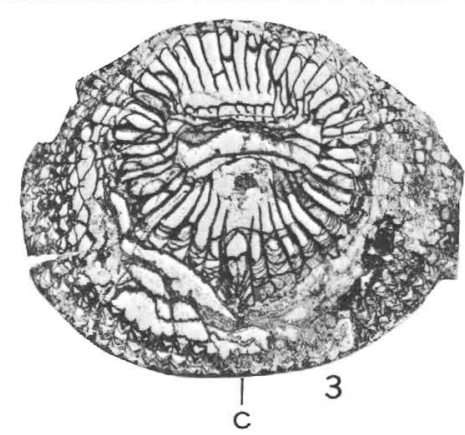




\section{PLATE 8}

FIGURES 1-4. Lonsdaleia (Actinocyathus) stelcki (Nelson) (p. 21).

USNM 165171, collection 104.

1. Transverse thin section $(\times 2)$; USNM 165171a.

2. Longitudinal thin section $(\times 2)$; USNM $165171 b$.

3. Enlarged view of some of the corallites shown in fig. $2(\times 4)$.

4. Enlarged view of some of the corallites shown in fig. $1(\times 4)$. 
GEOLOGICAL SURVEY

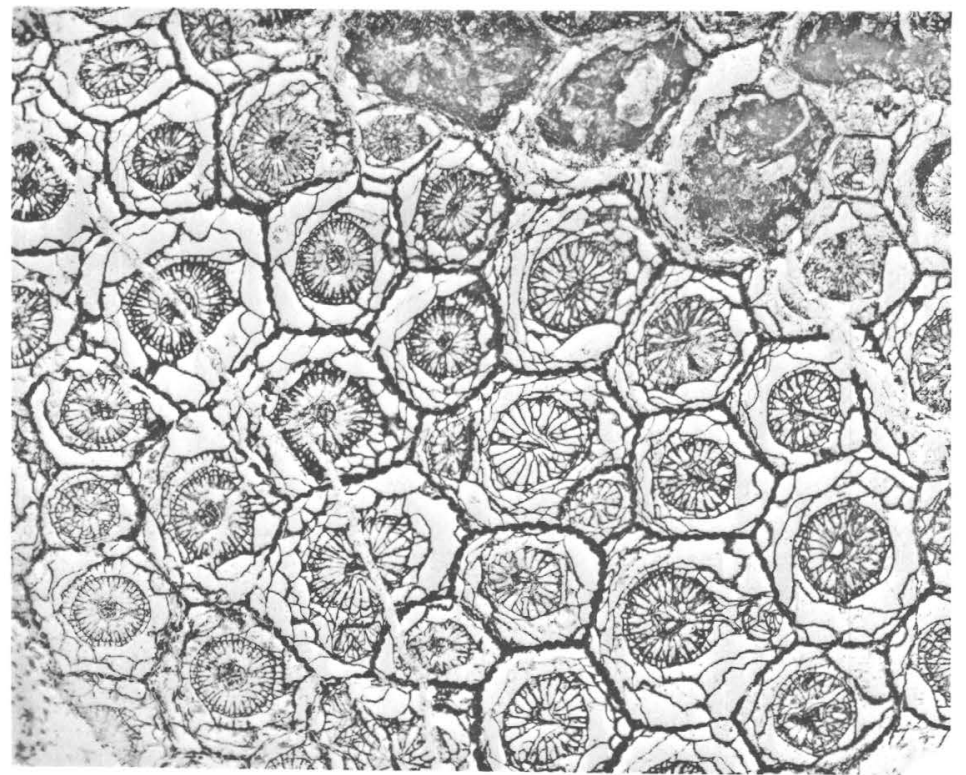

1

PROFESSIONAL PAPER 848-C PLATE 8

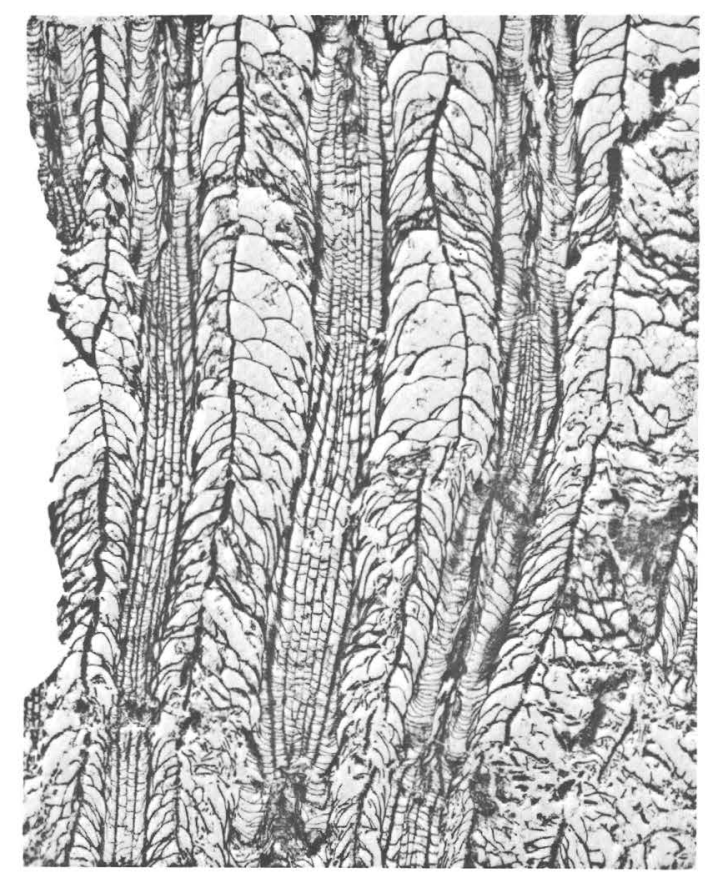

2

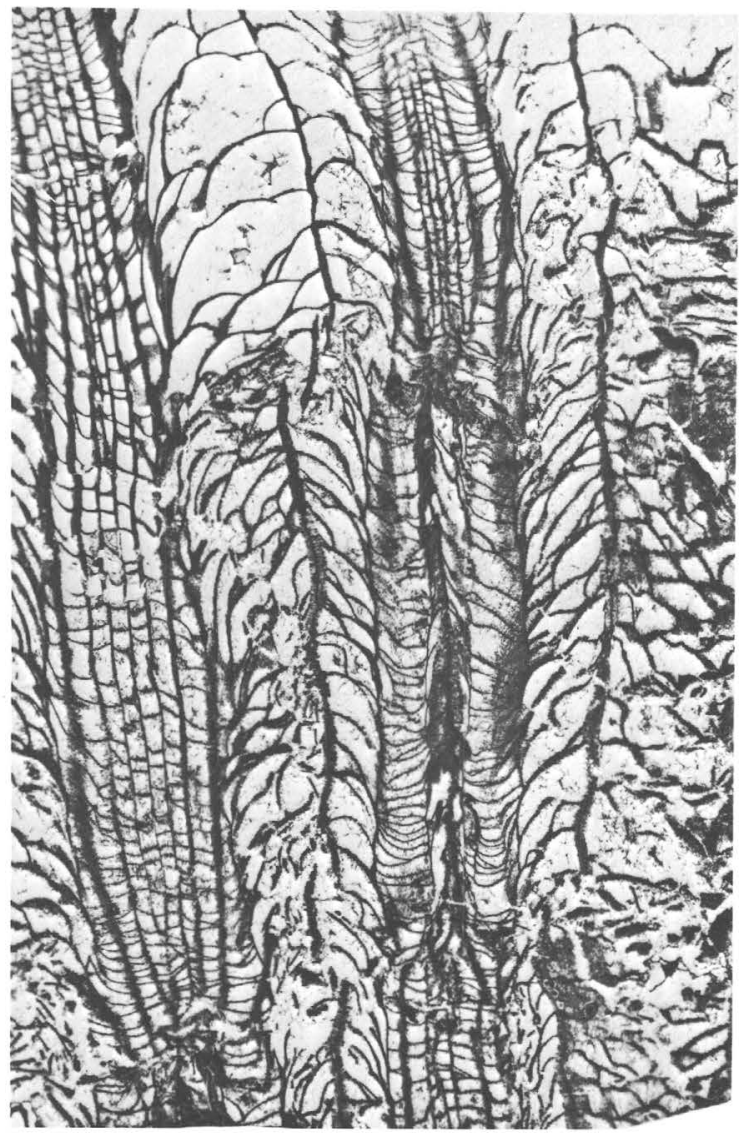

3

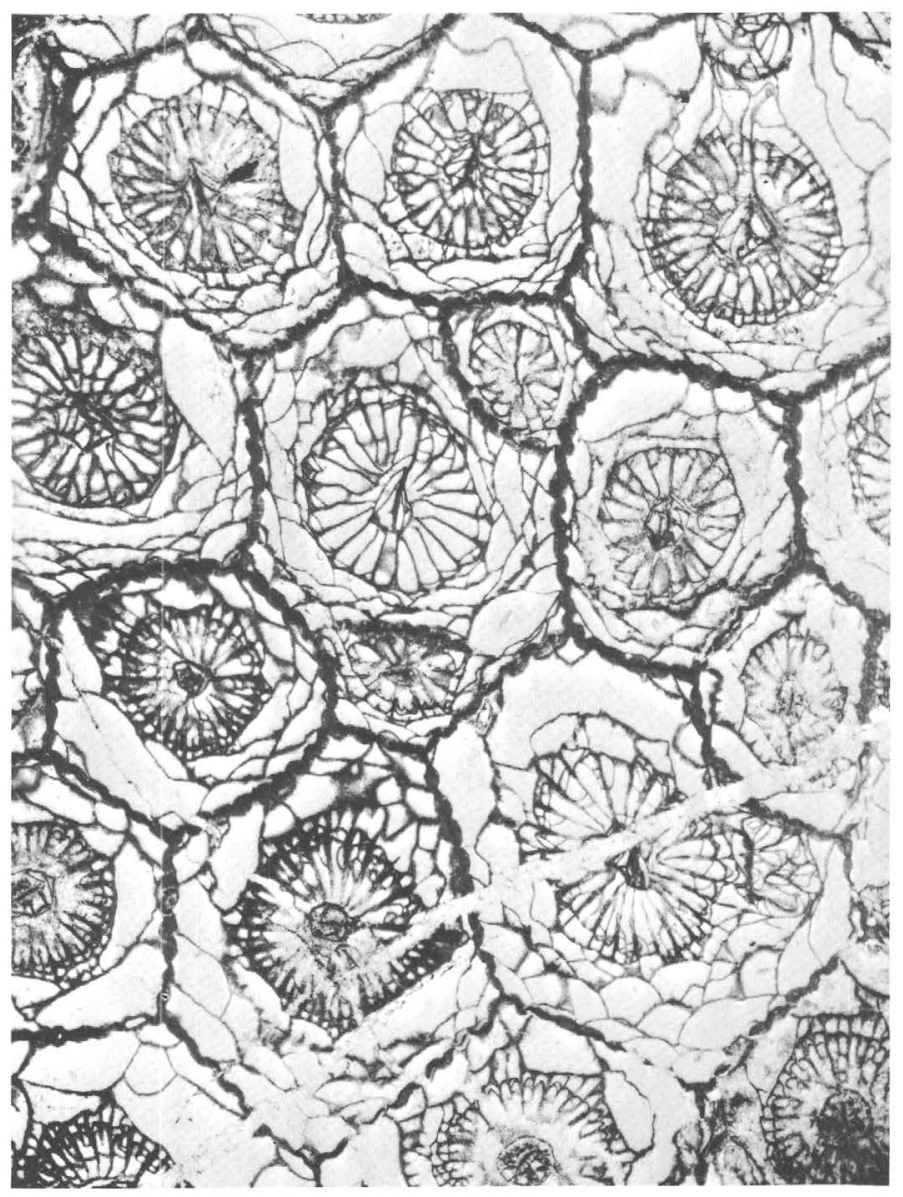

4

LONSDALEIA (ACTINOCYATHUS) STELCKI (NELSON) 


\section{PLATE 9}

FIGURES 1-4. Pleurosiphonella drummondi (Nelson) (p. 24).

USNM 165174, collection 109.

1. Transverse thin section $(\times 4)$. USNM 165174a.

2. Longitudinal thin section $(x 1)$. USNM $165174 \mathrm{~b}$.

3. Transverse thin section $(\times 1)$. USNM 165174a.

4. Longitudinal thin section ( $\times 4)$. USNM $165174 \mathrm{c}$.

5-9. Multithecopora? amsdenensis n. sp. (p. 25).

5-8. Holotype. USNM 165177, collection 105.

5. Transverse thin section $(\times 4)$. USNM 165177a.

6. Longitudinal thin section $(\times 4)$. USNM $165177 \mathrm{~b}$.

7. Transverse thin section $(x 1)$. USNM 165177 a.

8. Longitudinal thin section ( $\times 1$ ). USNM $165177 \mathrm{~b}$.

9. Side view of silicified specimen $(\times 2)$; paratype; USNM 165178 , collection 80 . 
GEOLOGICAL SURVEY
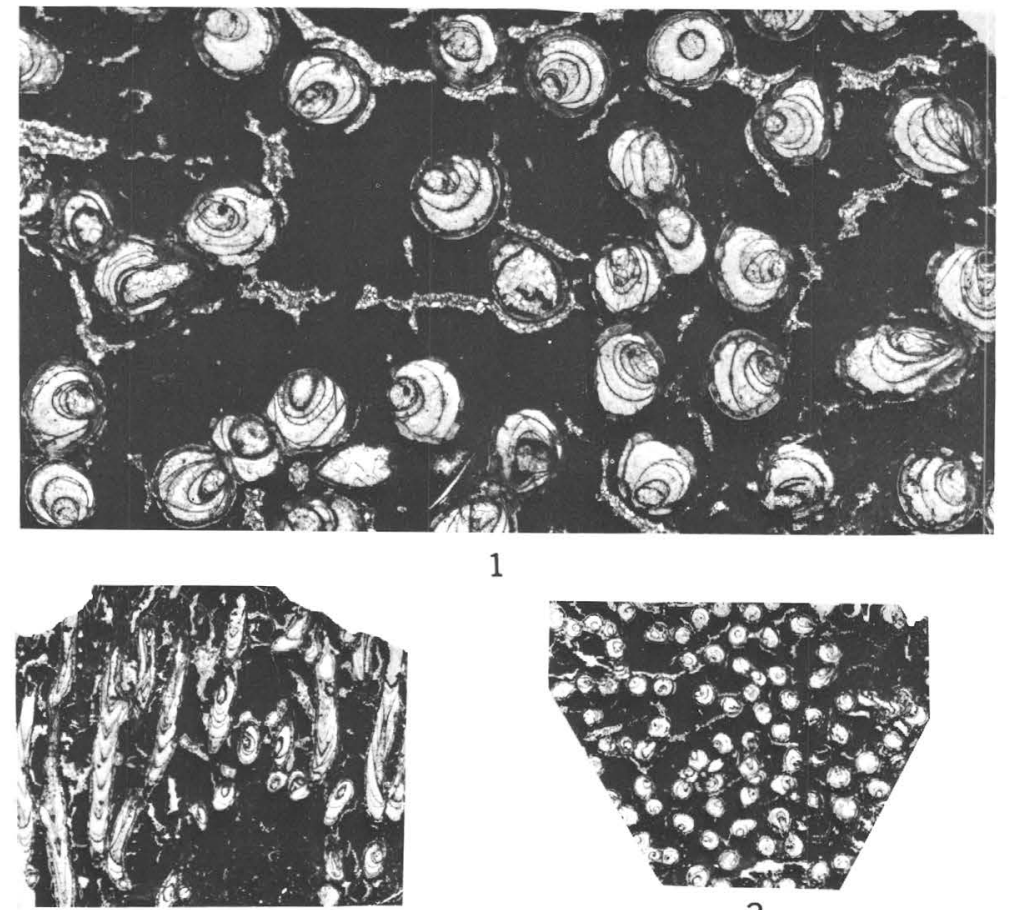

2

1

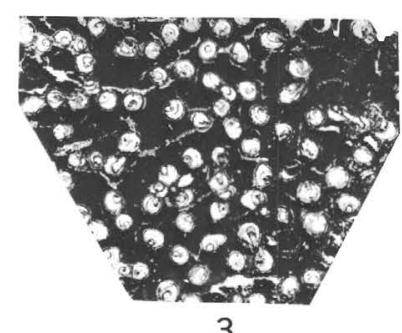

3

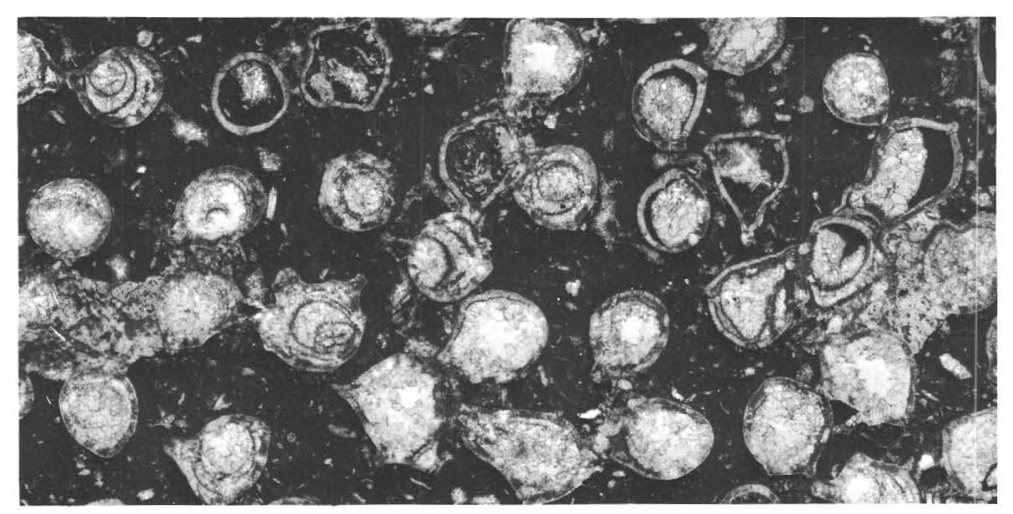

\section{5}
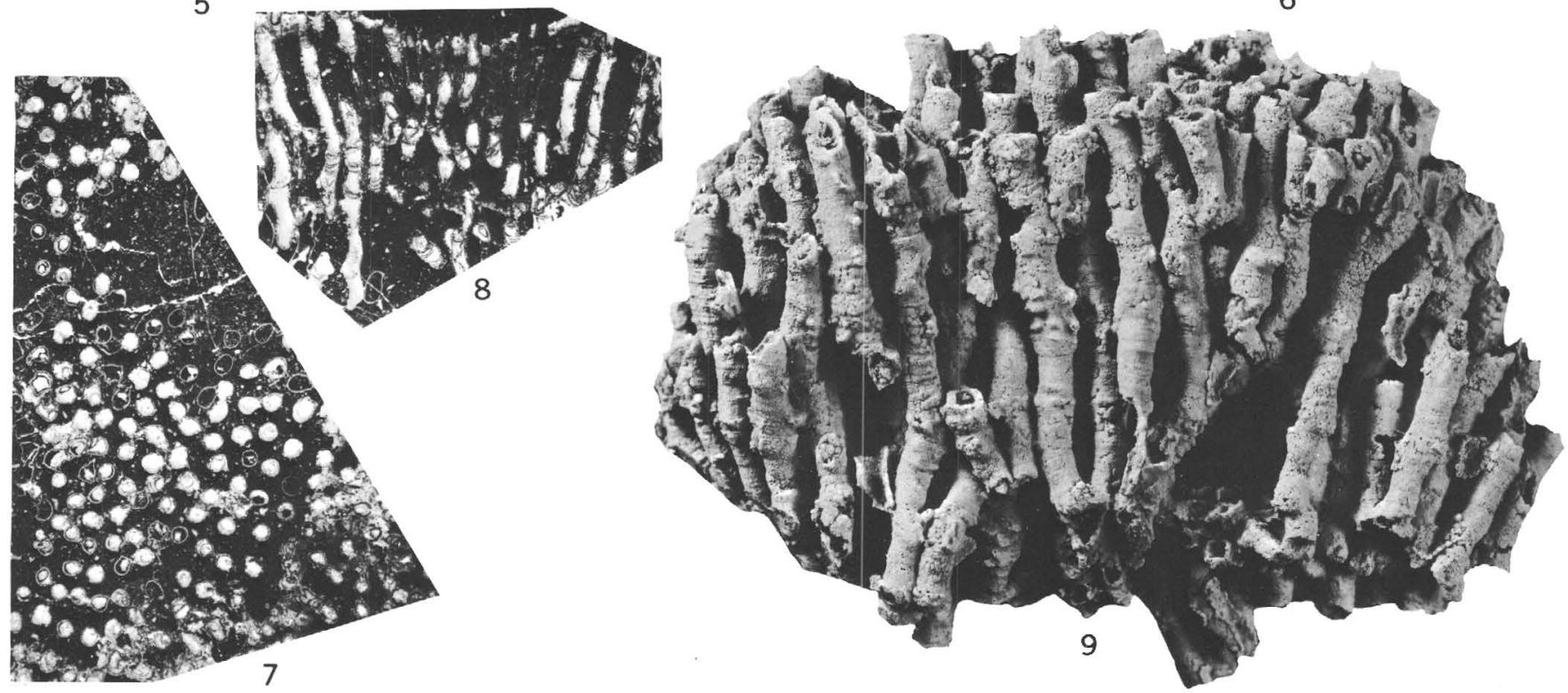

PLEUROSIPHONELLA DRUMMONDI (NELSON) AND MULTITHECOPORA? AMSDENENSIS N. SP. 


\section{PLATE 10}

FIgURES 1-6. Duncanopora duncanae n. sp. (p. 27).

1-4. Holotype. USNM 165184, collection 80.

1. Transverse thin section $(\times 1)$. USNM 165184a.

2. Longitudinal thin section $(\times 1)$. USNM 165184b.

3. Enlarged view $(\times 4)$ of some of the corallites shown in fig. 1.

4. Enlarged view $(\times 4)$ of some of the corallites shown in fig. 2.

5,6. Paratype. USNM 165187, collection $77(\times 1)$.

5. Longitudinal thin section. USNM 165187a.

6. Transverse thin section. USNM $165187 \mathrm{~b}$. 
GEOLOGICAL SURVEY

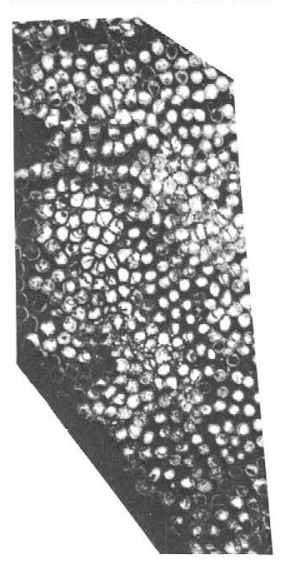

1

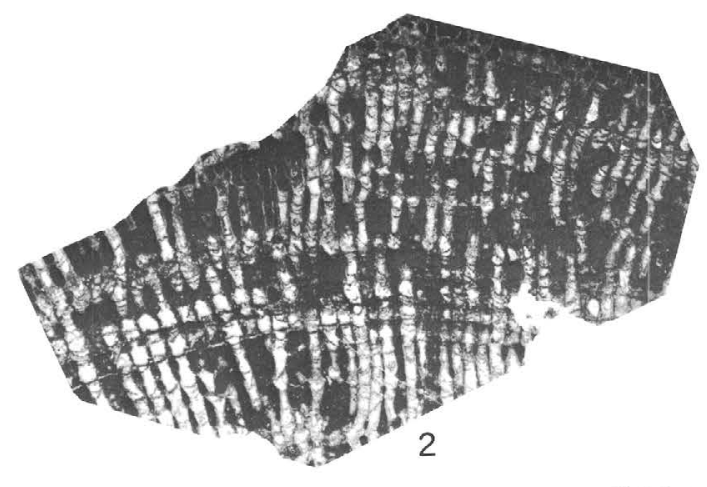

efortosto Ans.? 4all
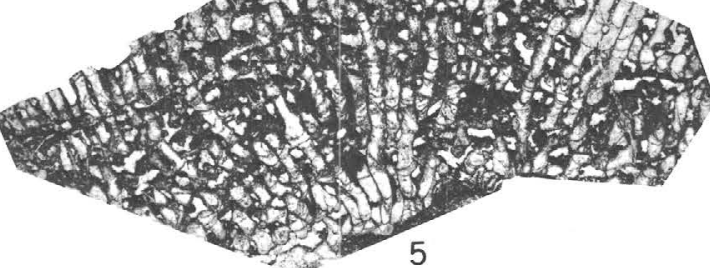

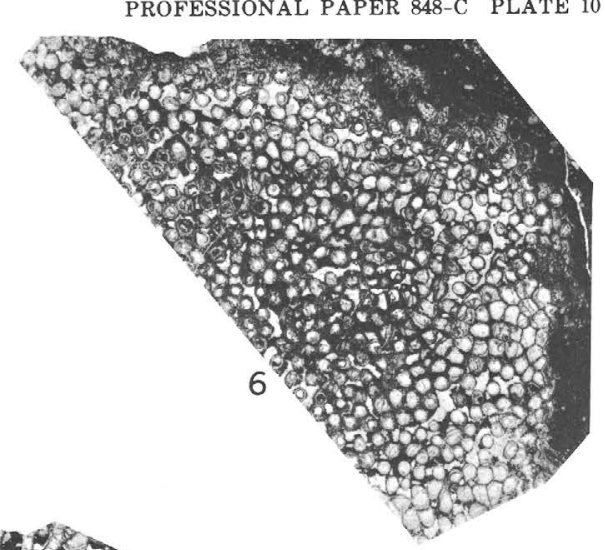

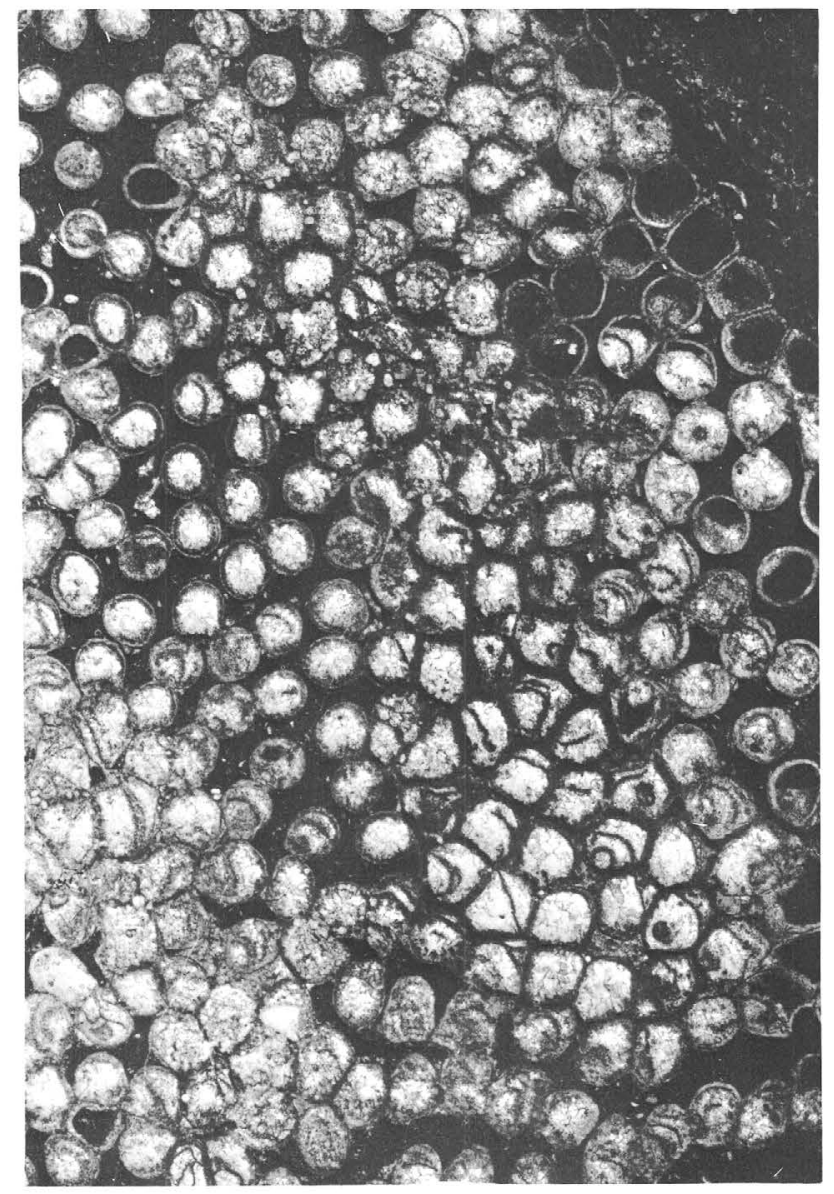

3

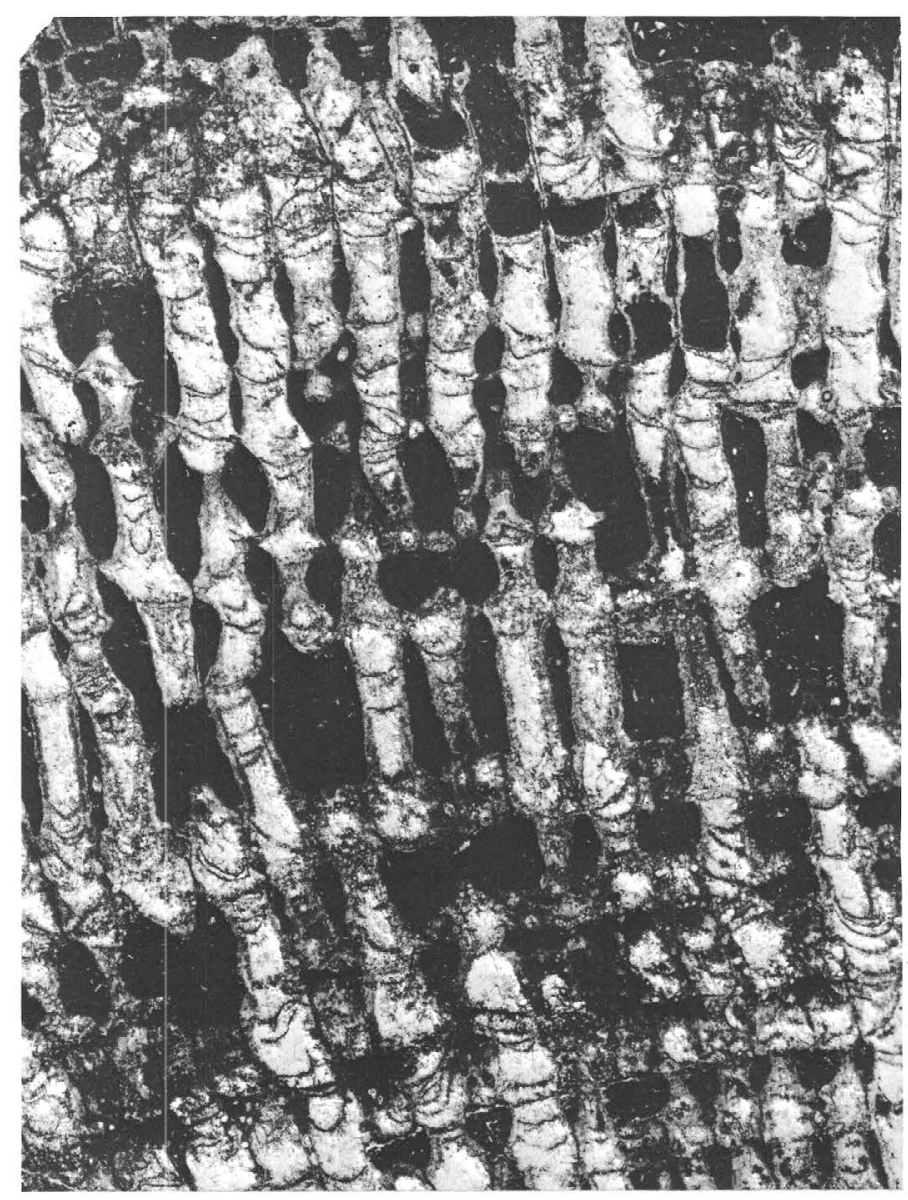

4

DUNCANOPORA DUNCANAE N. SP. 


